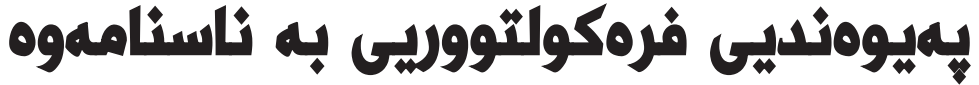

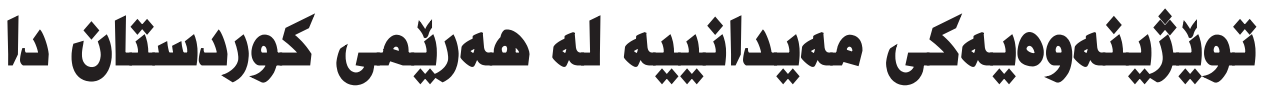

ب.ب.د. بـ عبدالمجيد غفور ابراهيم

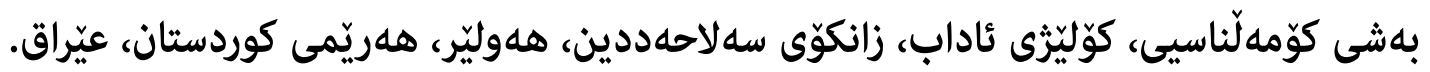
alkurdy_20@yahoo.com جبار قادر احمد - خويْندكارى دكتورا

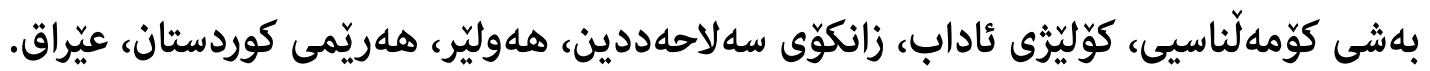
jabarqader79@gmail.com

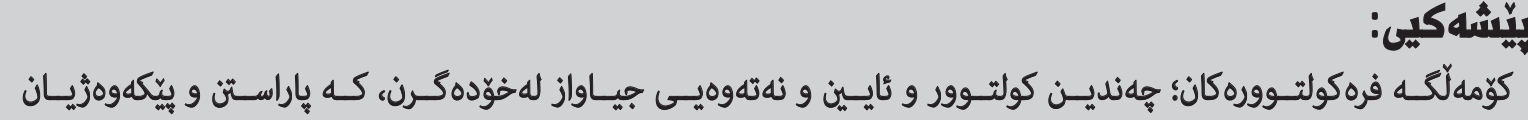

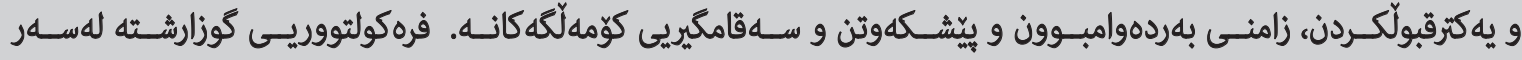

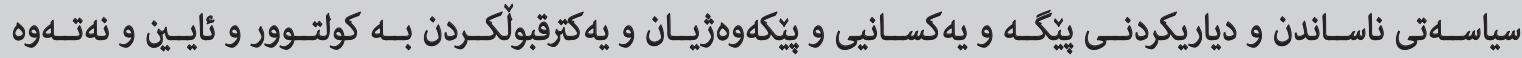

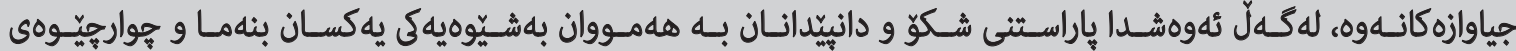

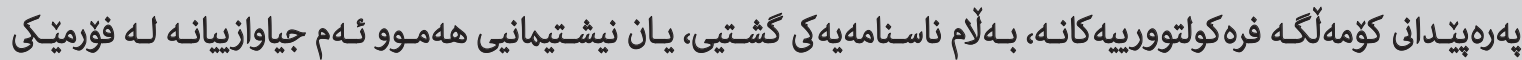

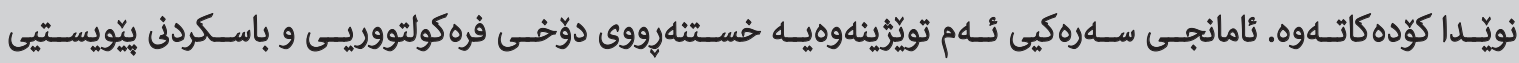

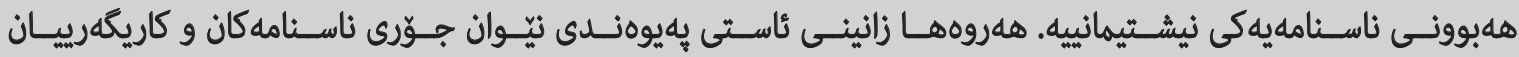

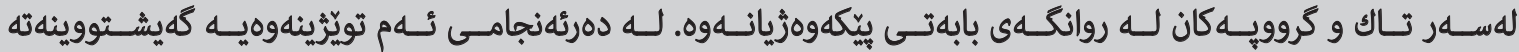

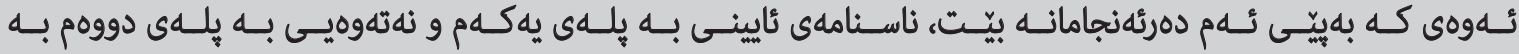

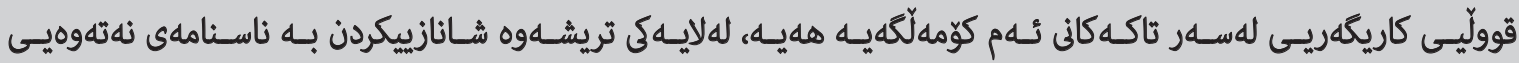

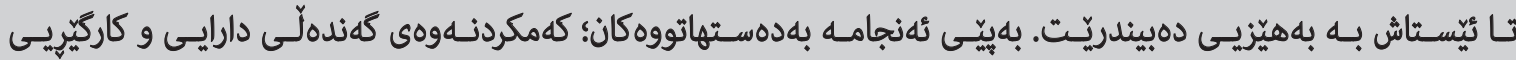

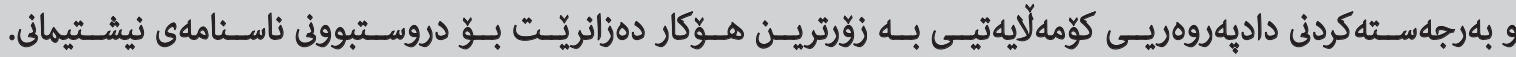

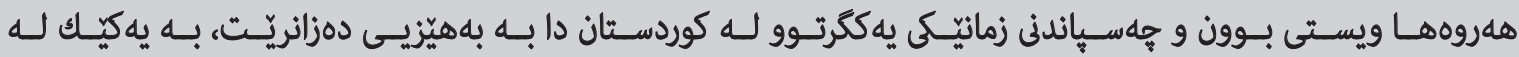

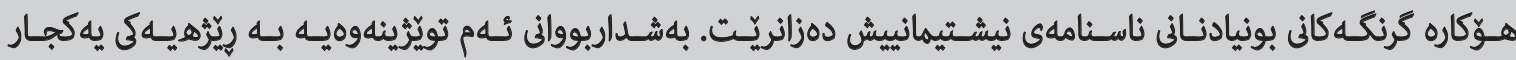

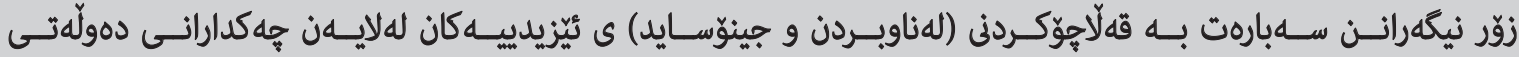

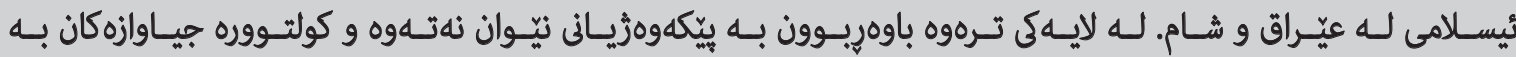

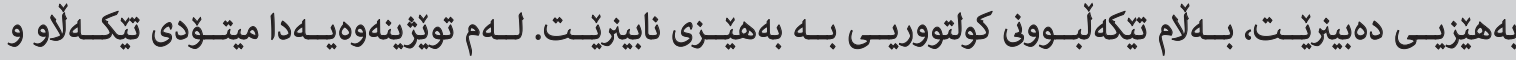

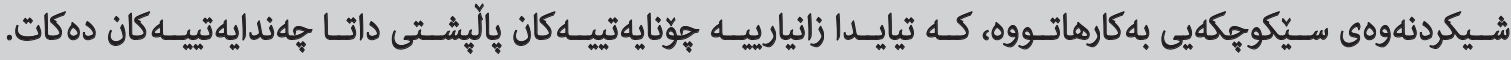
كليله وشهكان: فرهكولتووريى، ناسنامه، ناسنامهى نيشتيمانه، بيّكهوهزيان و هاوبهنديى كوّمهلآلايهتيى. 


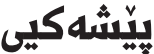

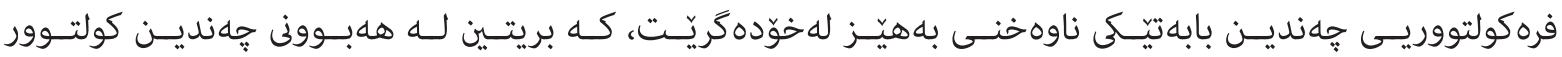

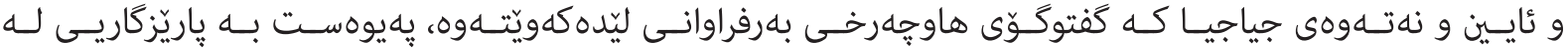

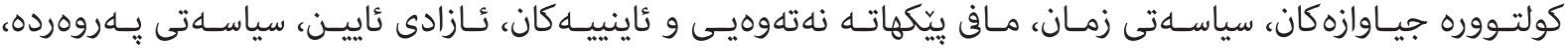

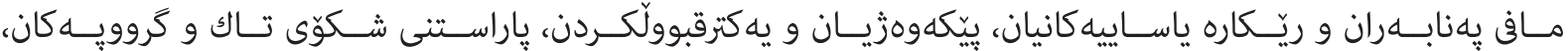

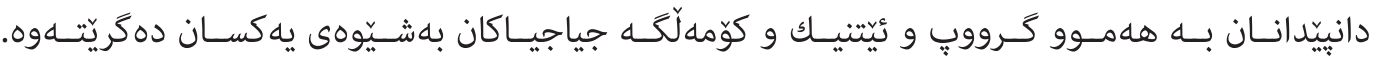

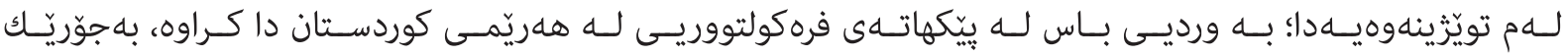

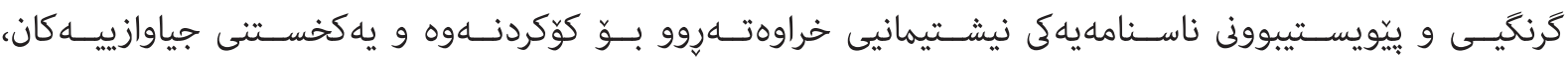

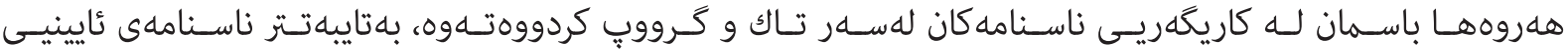

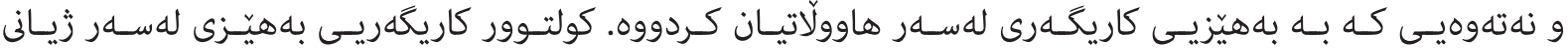

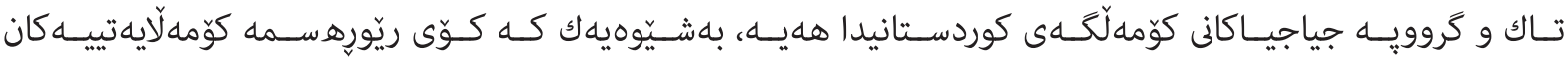

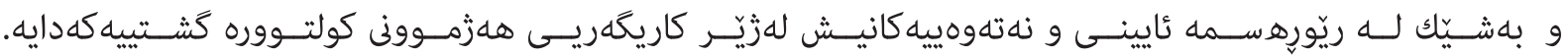

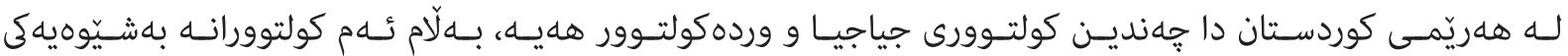

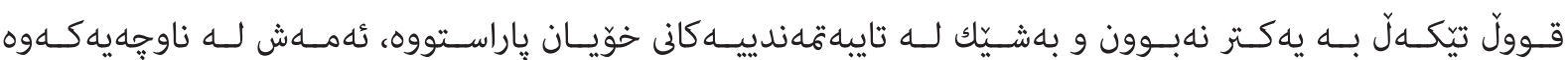

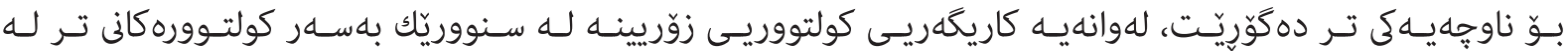

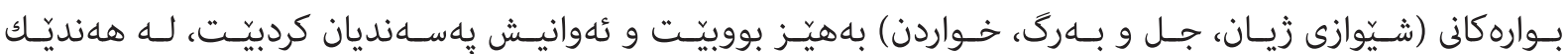

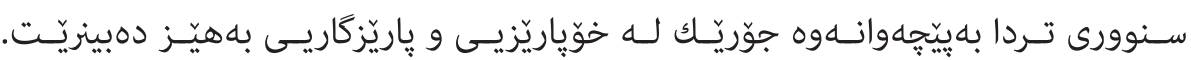

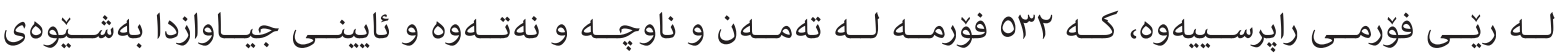

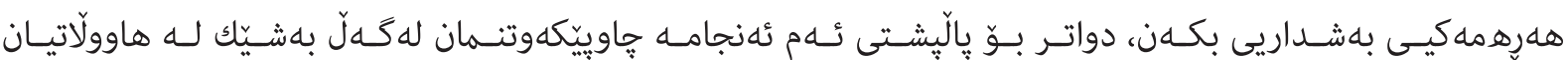

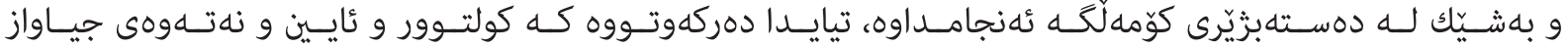

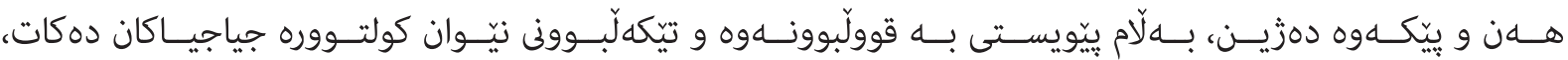

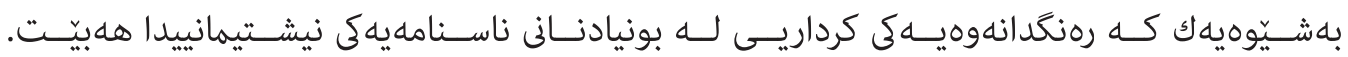

تهوهرهانى تويُرثينهوه

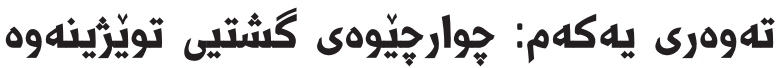
كيّشهى تويّرَينهوهكه

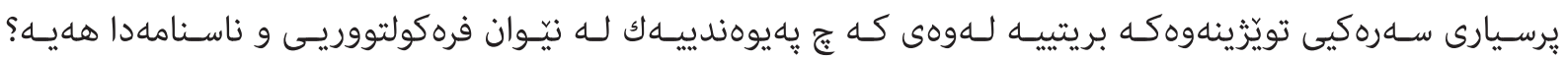

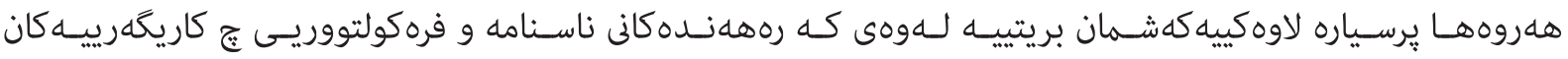

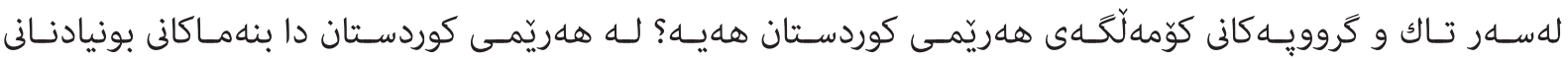

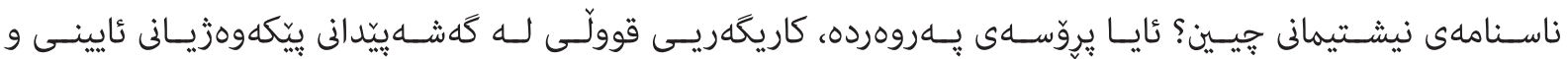




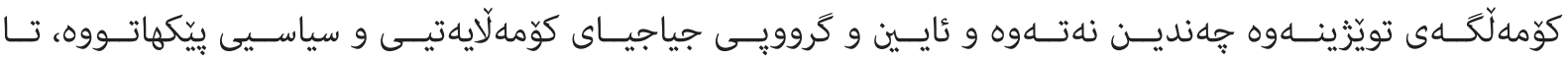

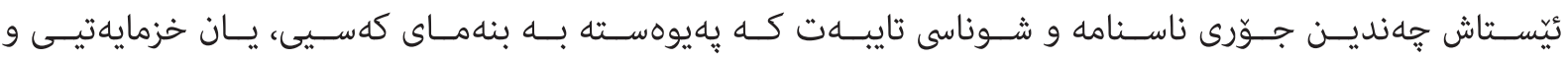

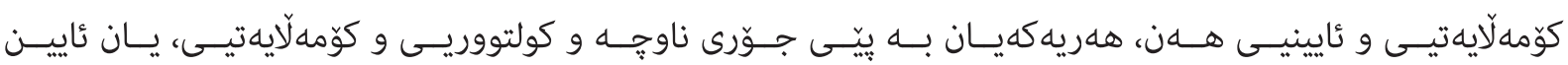

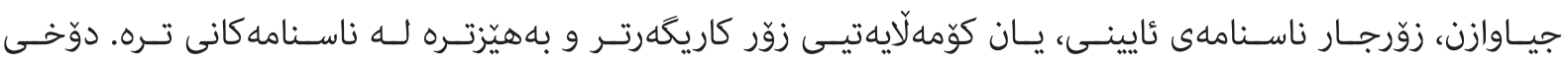

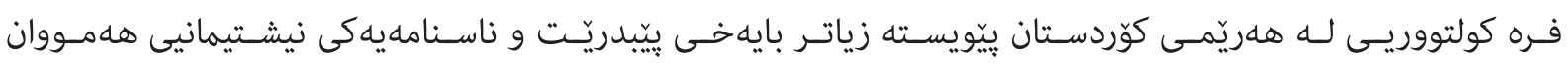

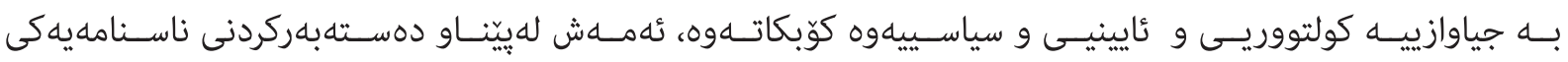

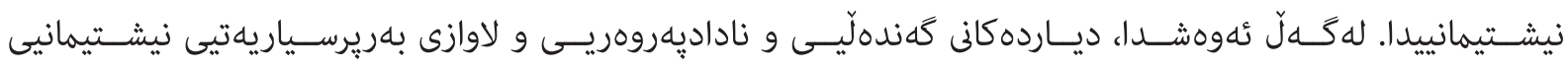

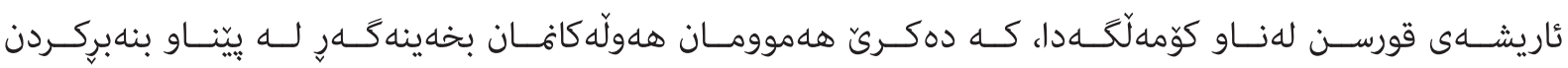

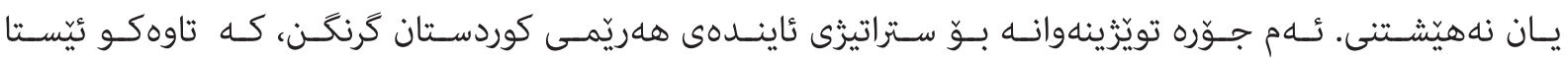

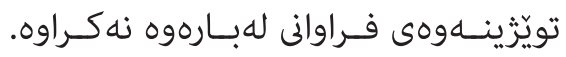

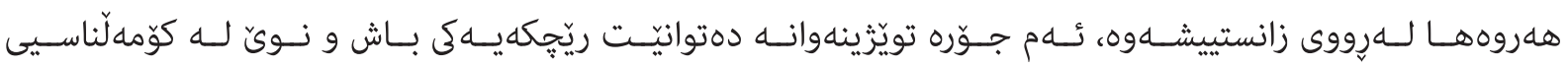

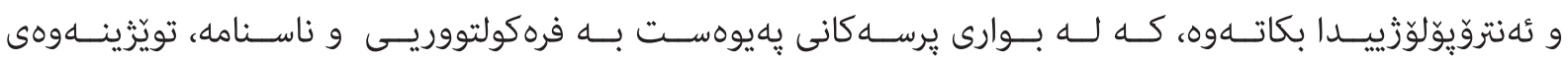

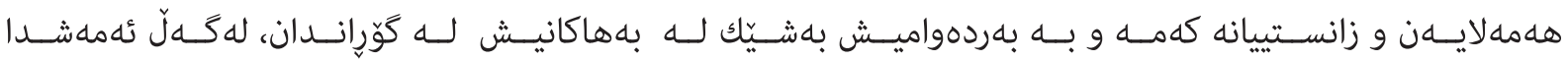

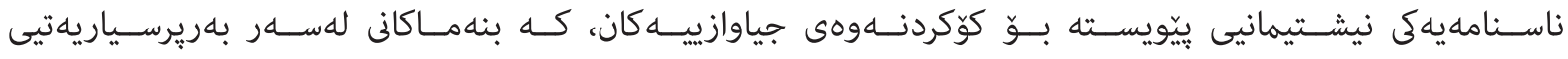

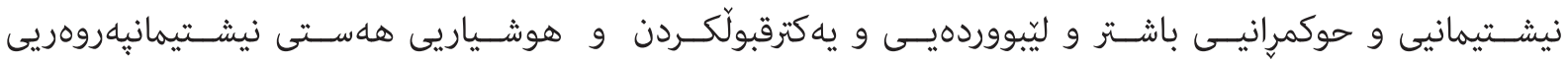
بونيادنــراون.

\section{ئامانجى تويَرِّينهوهكه}

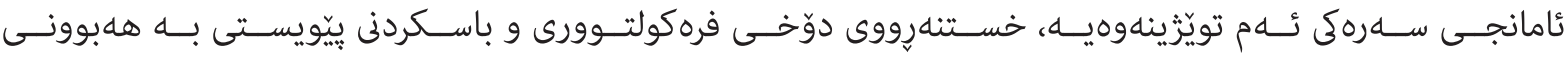

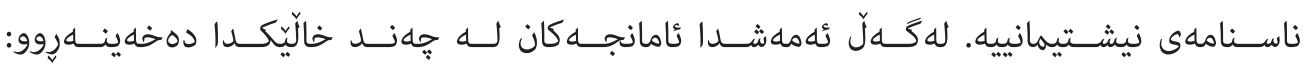
هلَّسهنكاندن و خستنهرووى دوّخى فرهولتووريى و ناسنامهيه له ب باشوورى كوردستان دا. رههندن و كاريكهرييه كانى فرهولتووريى له دياريكردنى ناسنامهى نيشتيمانيى هاوولّاتيان.

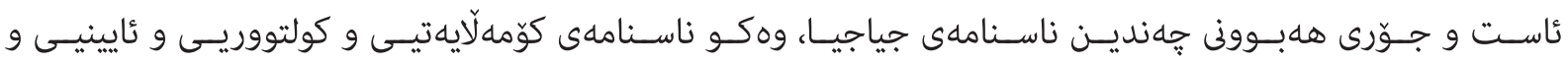

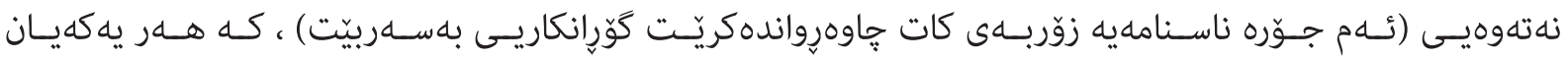

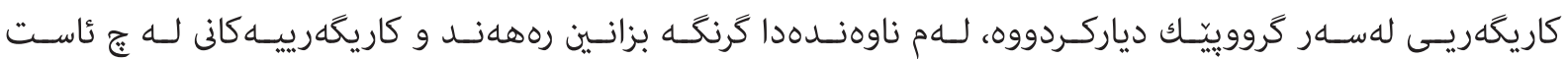

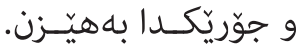

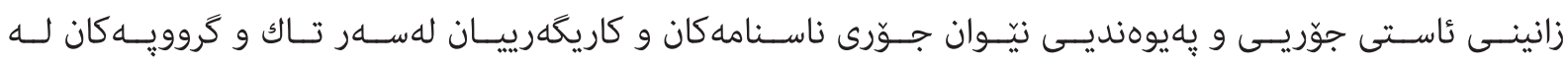

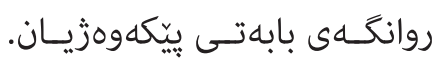

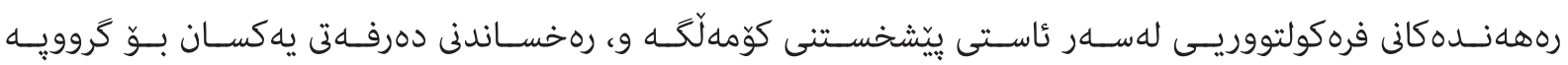

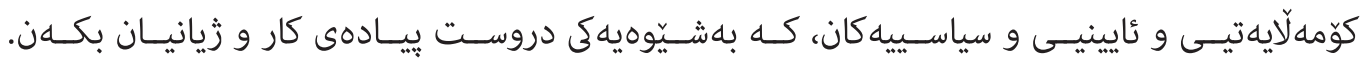




\section{جهمكه سلهركييهكانى تويَّرينهوهكه}

يهكهم: فره كولتووريى Multicultural:

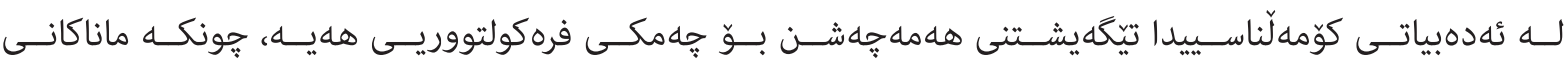

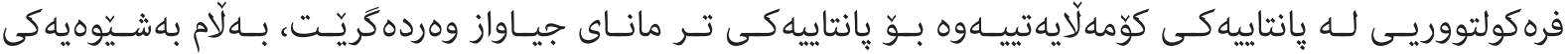

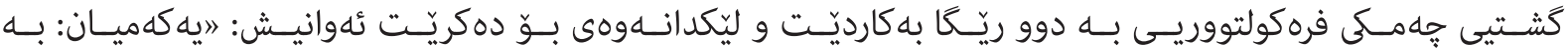

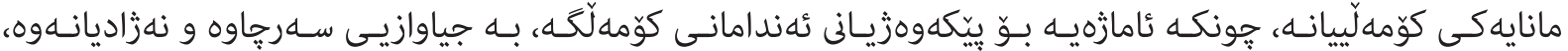

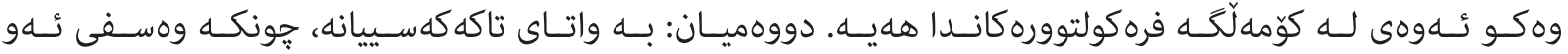

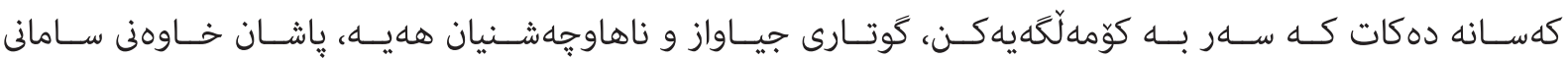

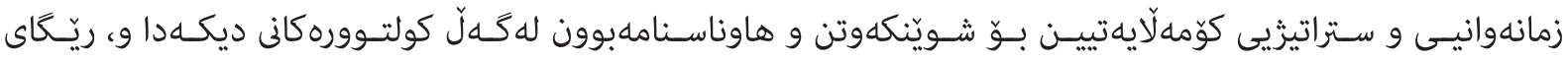

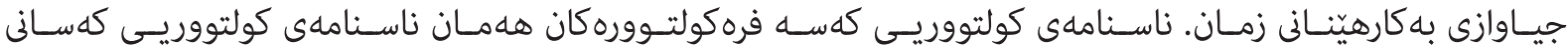

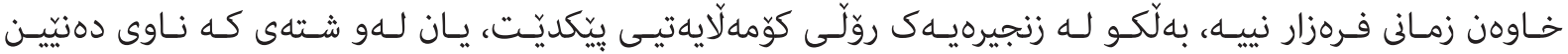

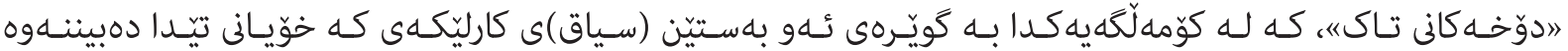

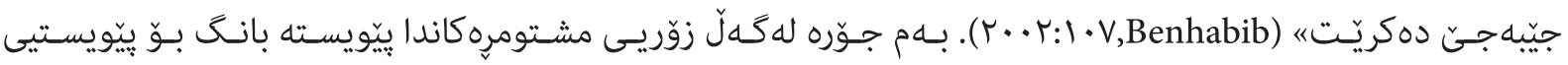

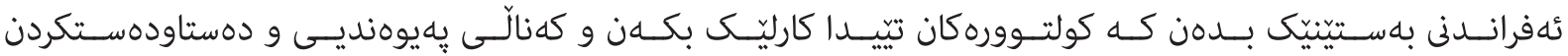

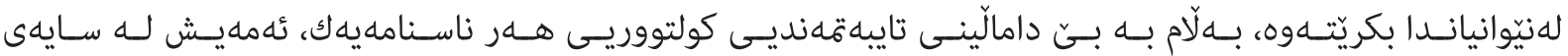

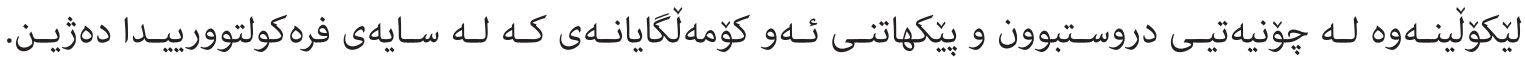

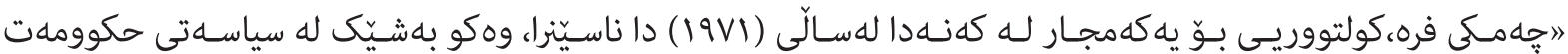

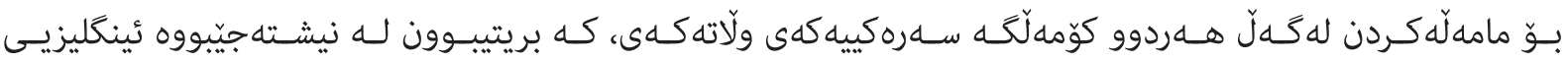

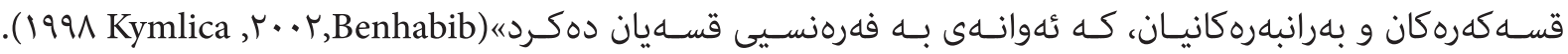

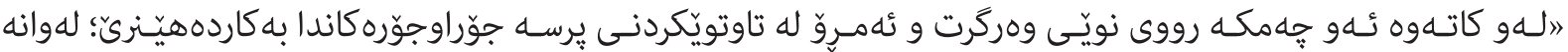

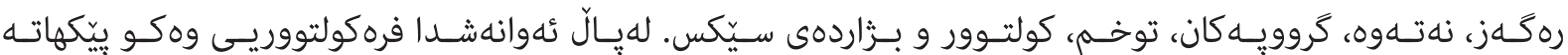

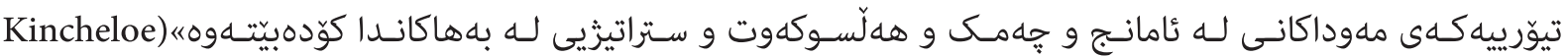

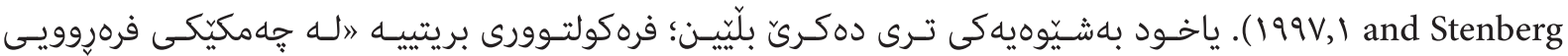

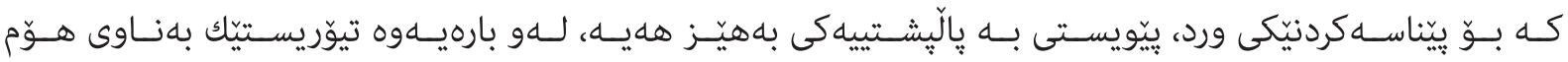
(homibhabha)

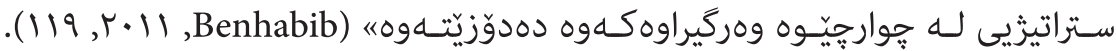

\section{يُّيناسهى ريّكاريى بوّ جهمكى فرهكولتووريى}

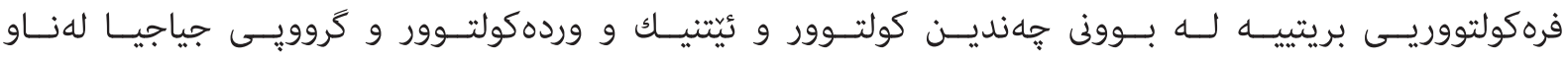

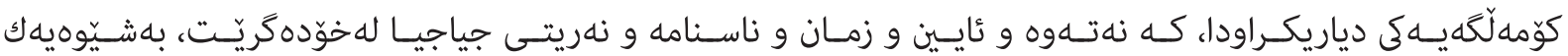

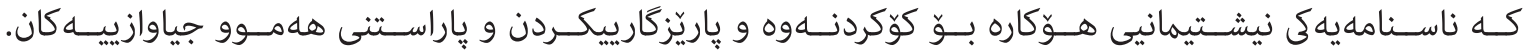
دووهم: ناسنامه Identity

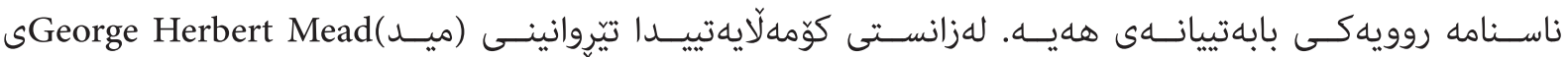




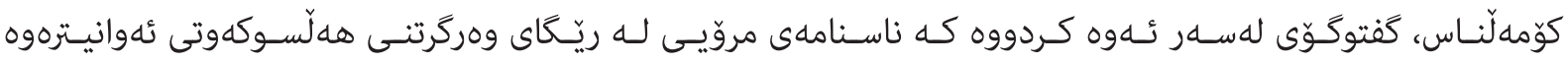

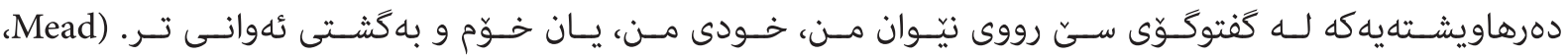

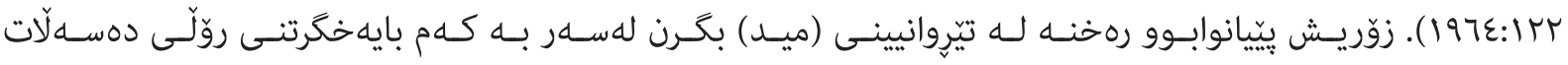

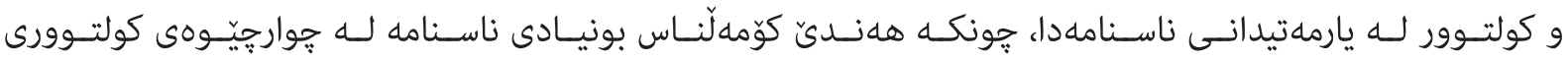

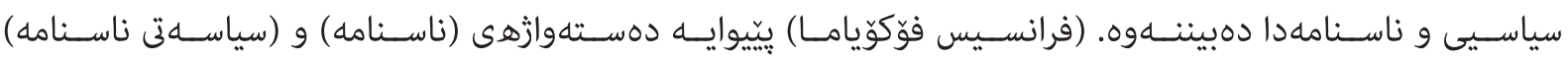

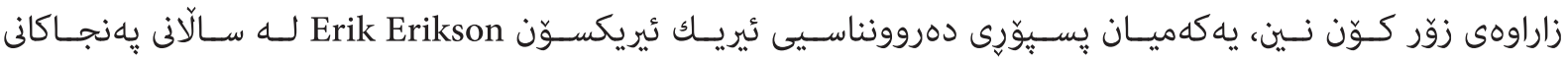

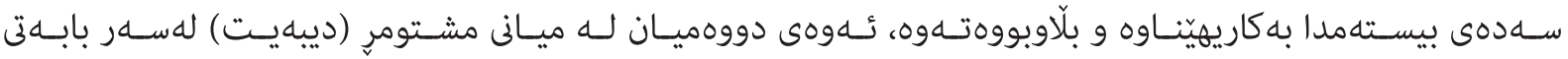

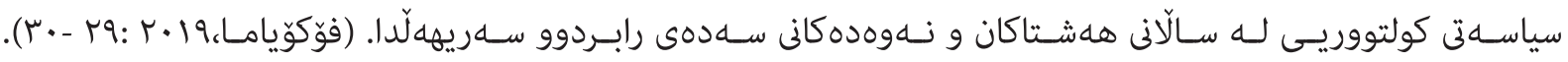

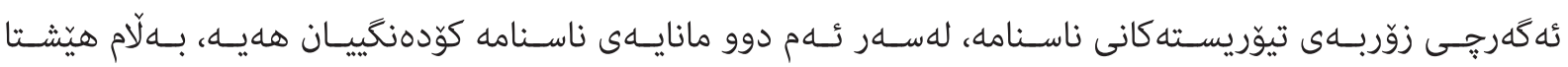

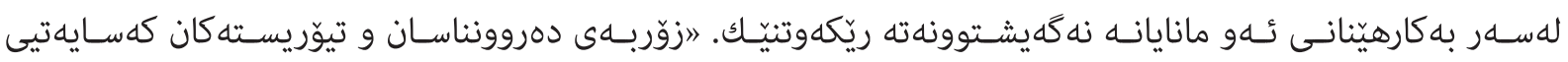

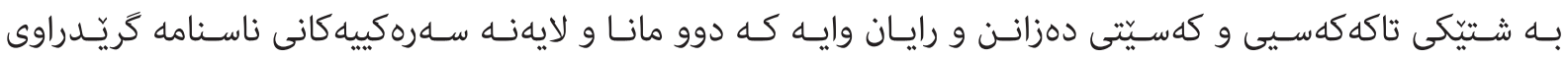

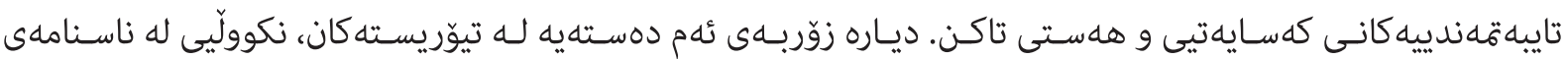

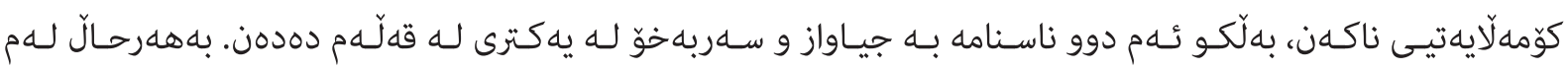

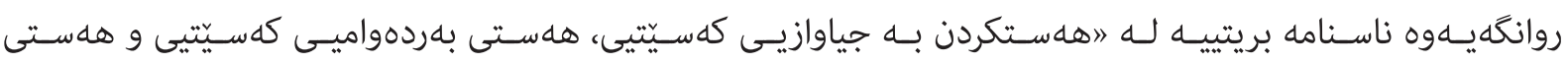

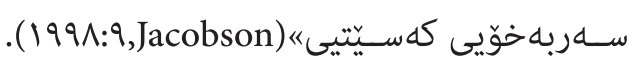

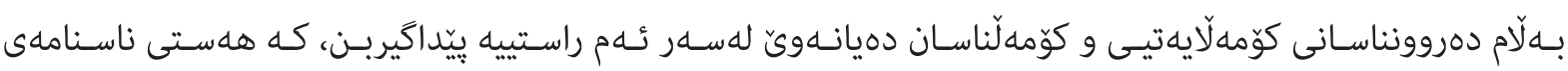

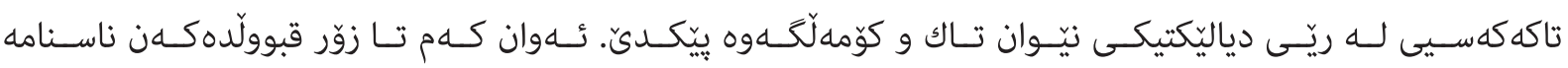

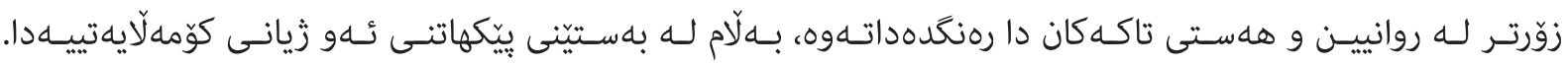

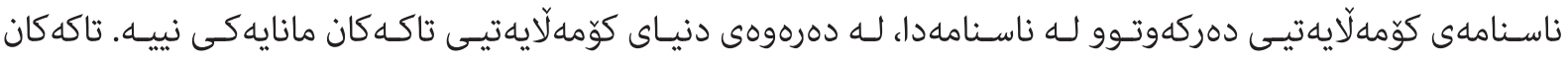

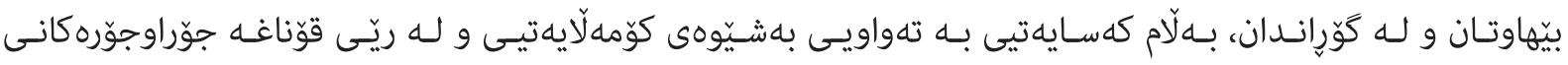

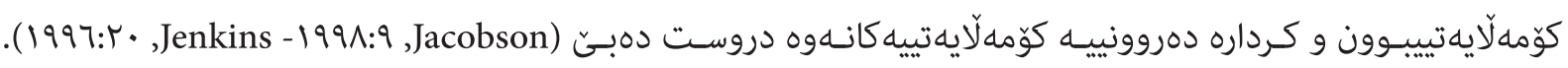

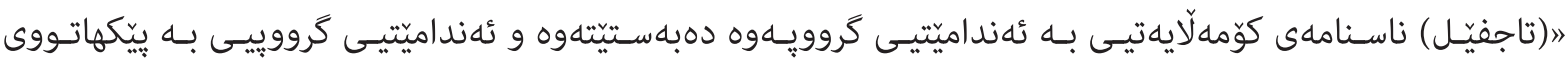

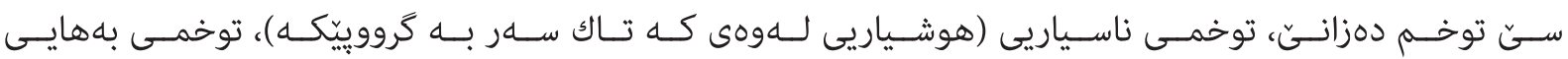

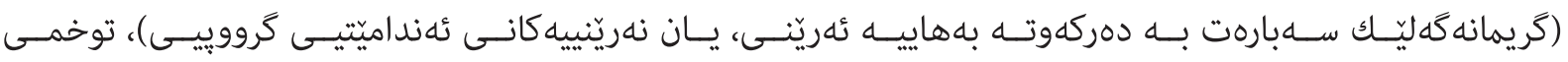

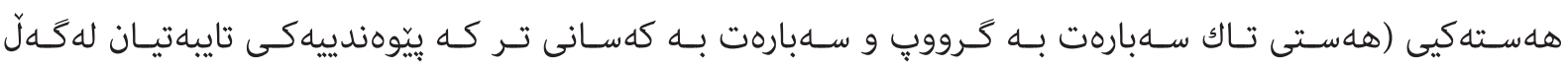

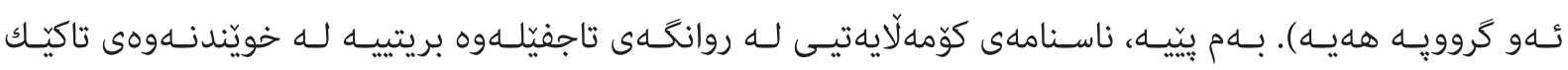

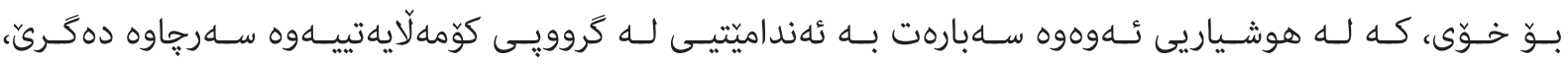

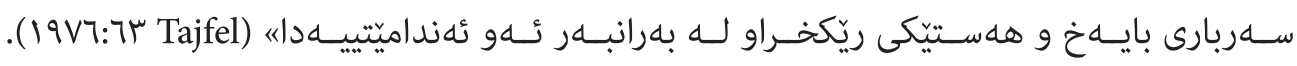

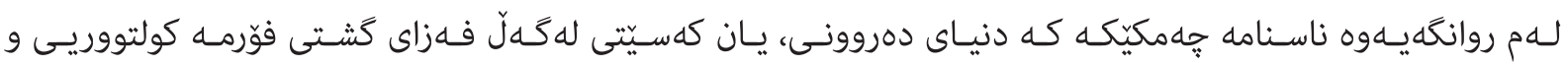

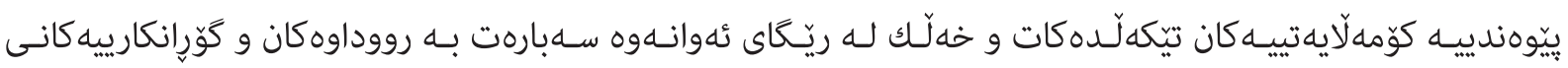

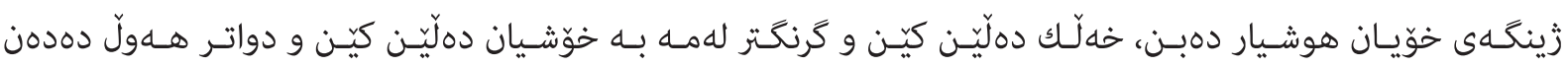

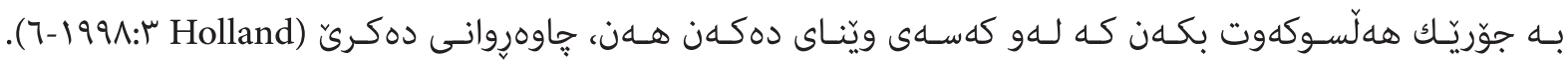


يِيّناسهى ريّكاريى بوّ جههكى ناسنامه

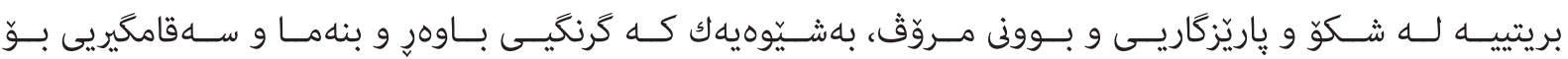

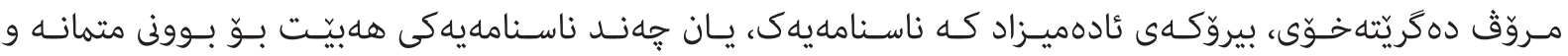

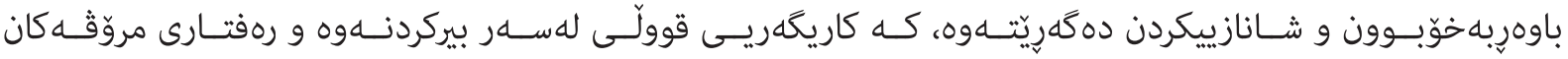

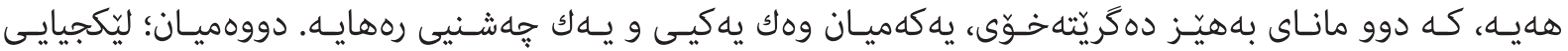

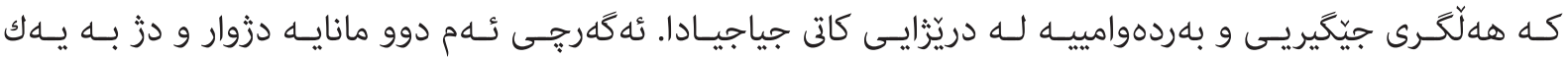

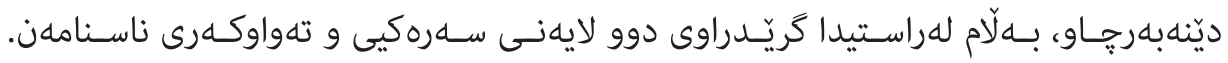

\section{تهوهرى دووهم: پاشخانى (باككراوند) تيوَرهكانى ناسنامه}

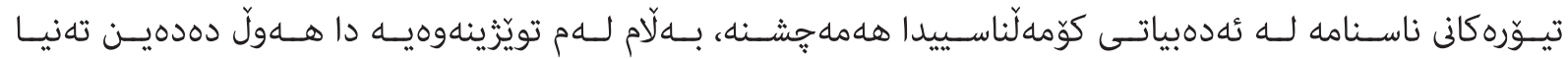

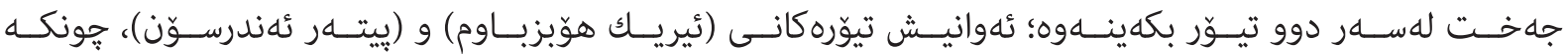

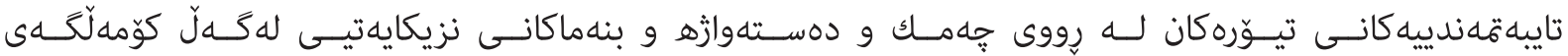

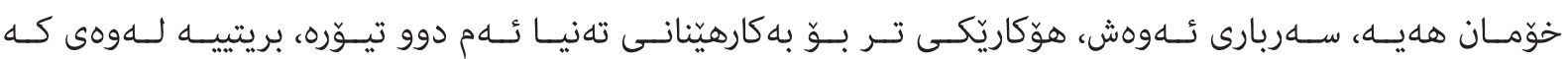

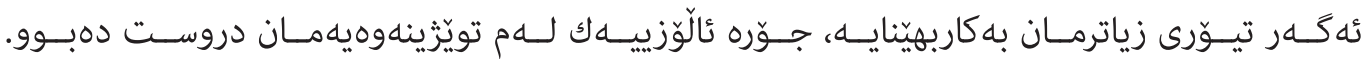

يهكهم: تيوّرى نئيريك هوّبزباوم Eric Hobsbawm:

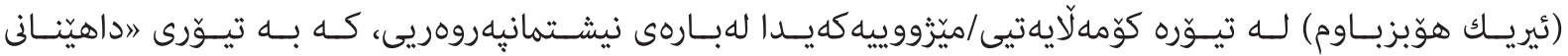

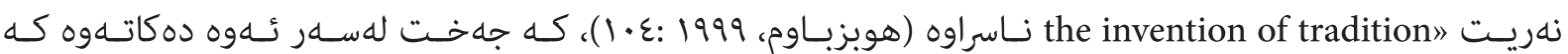

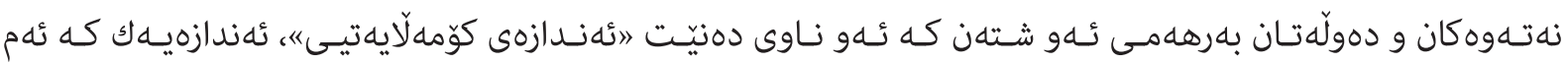

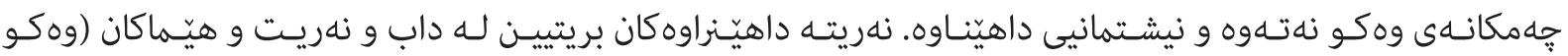
سروودى نيشـتيمانيى، جهزنـه نيتشـيمانييهكان، روّزى نيشـتيمانيى، ئهفسـانه كان، بوّنـه نه تهوهيسى و نيشـتيمانييه كان)،

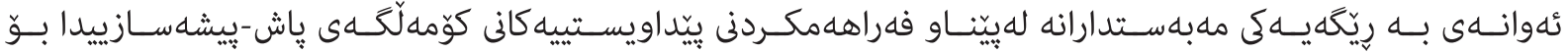

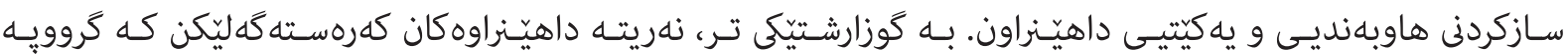

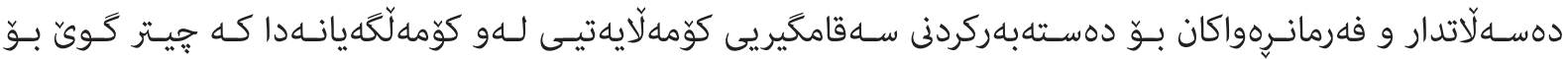

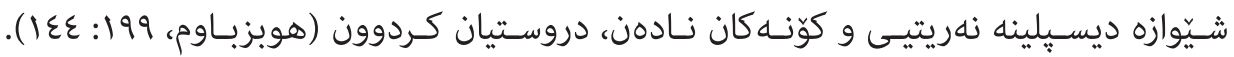

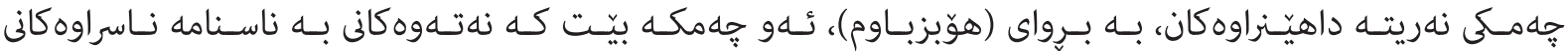

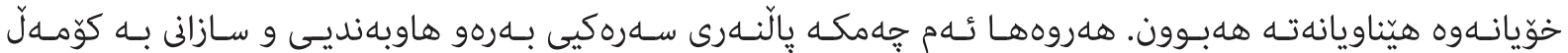

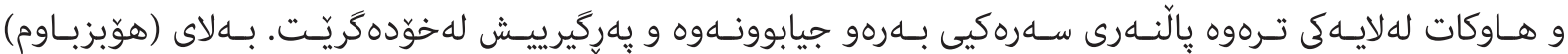

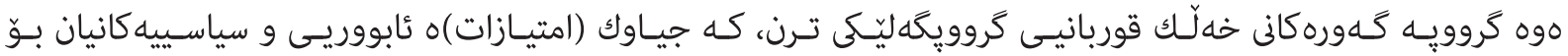

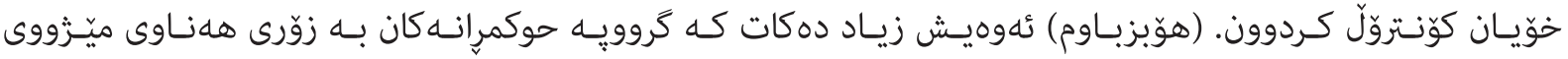

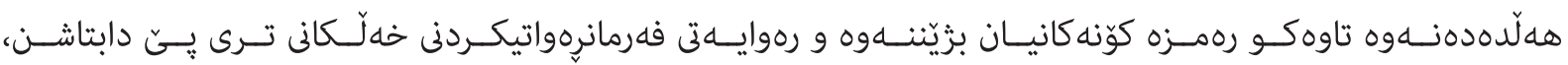

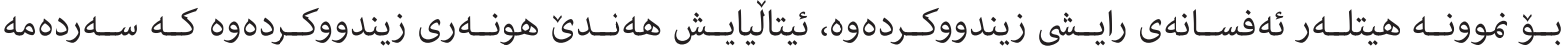

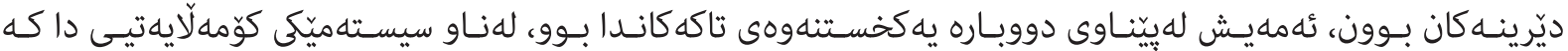


بالّهانه و موّنيوميّنت و يهيكهره يادهوهرييه كان.

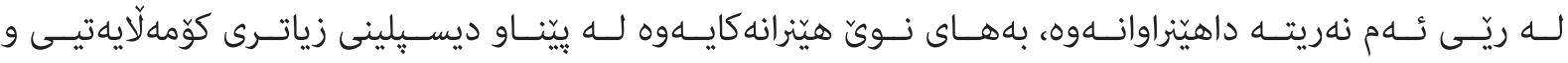

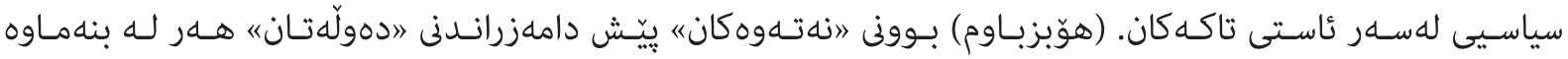

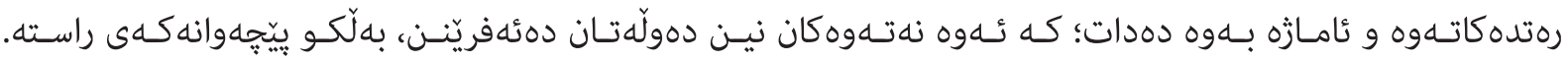

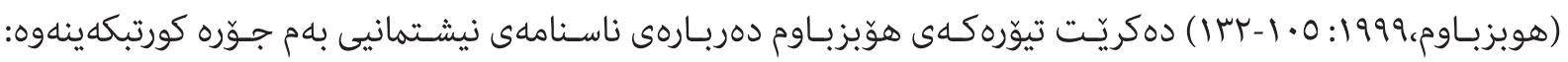
ميّزووى نهتهوهكان و ناسنامه نيشتمانييه كان له سهرهتاى سهدى نوّزدهوه دهستيّيدهات و كوَنتر نييه. نه تهوه كان و ناسنامه نيشتمانييه كان له روّزئاوادا بهرهنجامى يروّسهى به بيشه سازييكردن بوون .

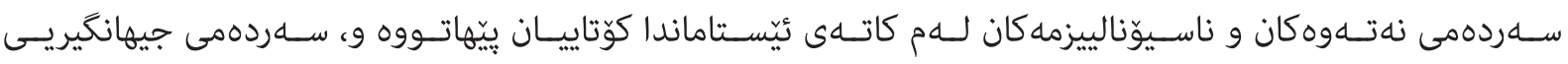

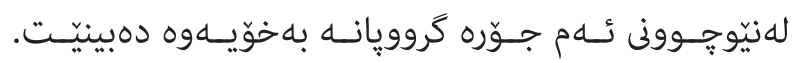

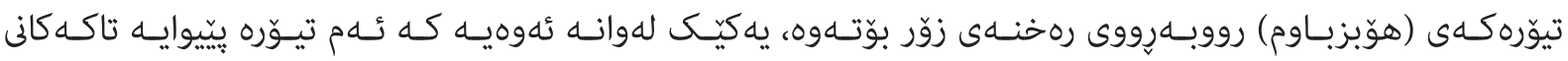

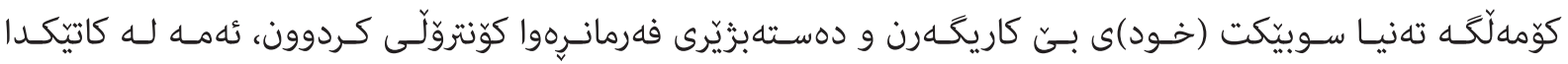

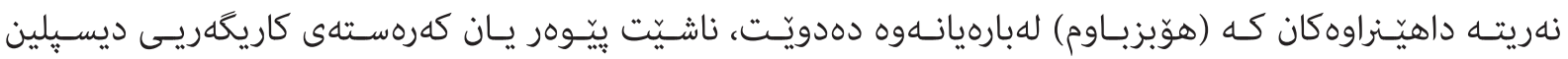

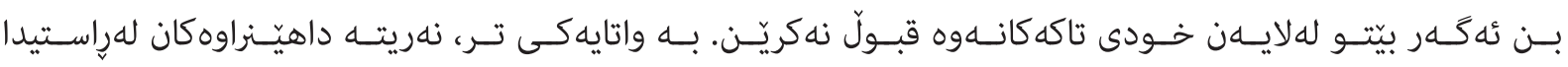

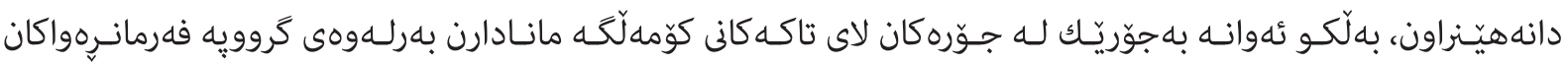

$$
\text { يشـتيوانييان لـئ كردبـن. }
$$

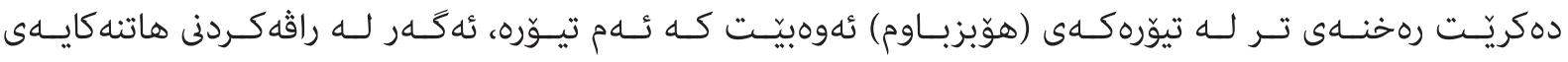

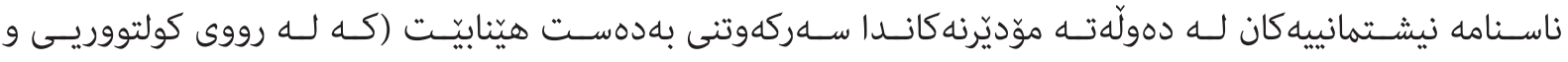

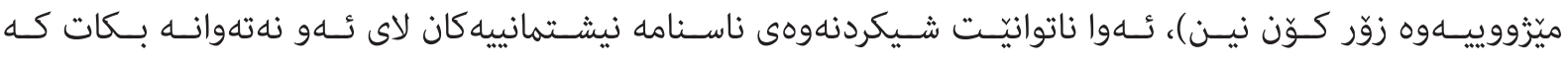

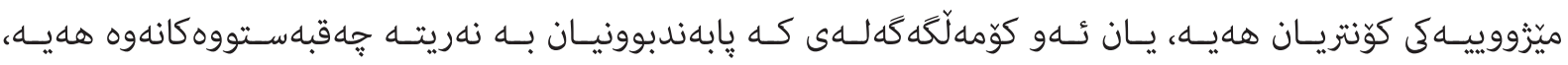

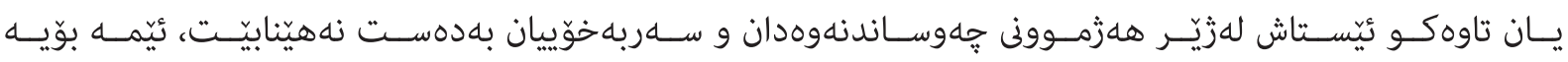

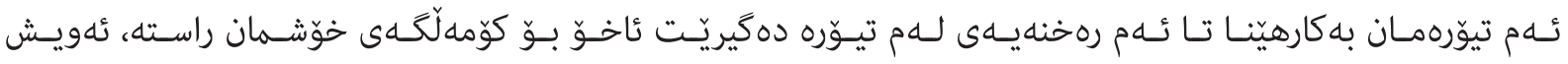

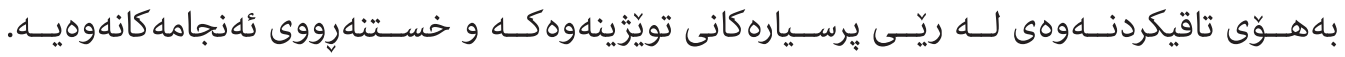
دووهم: تيوّرى بييتهر ئهندرسوّن:

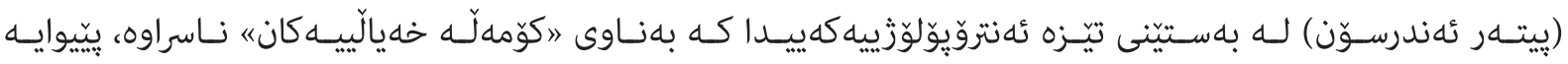

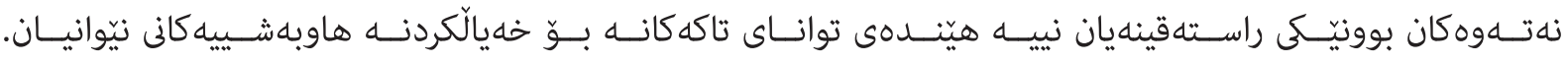

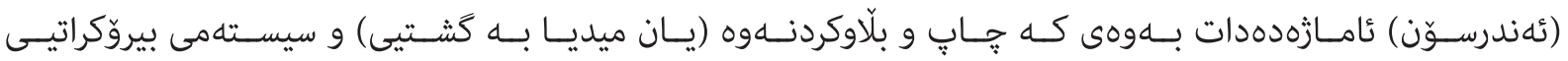

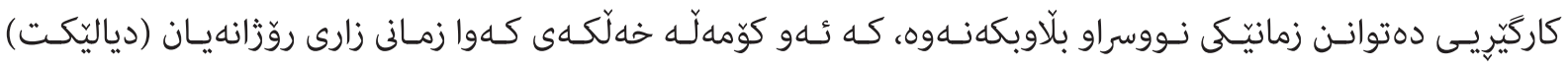

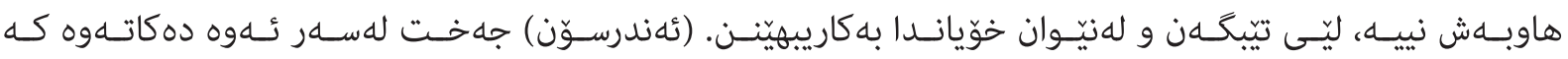

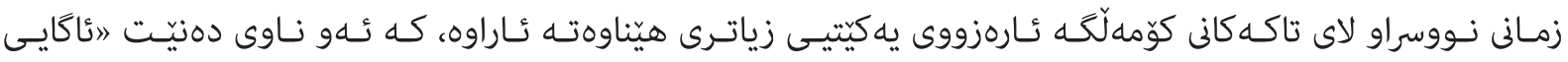




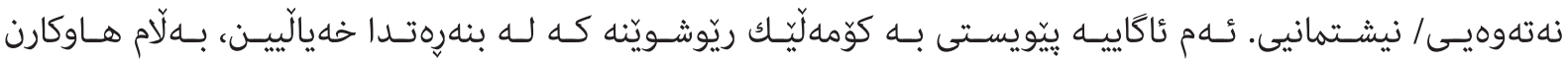

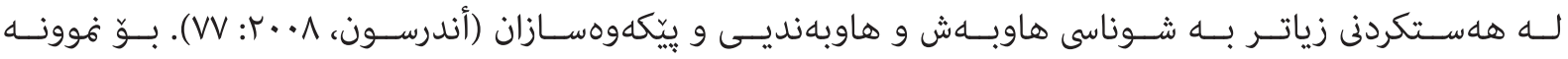

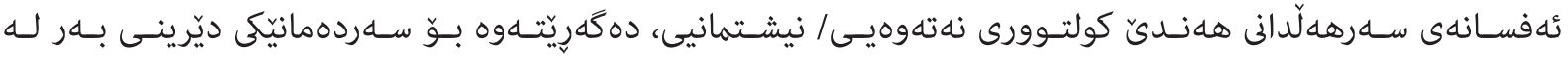

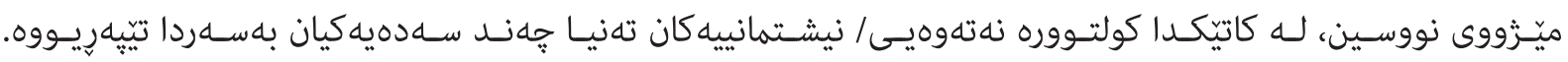

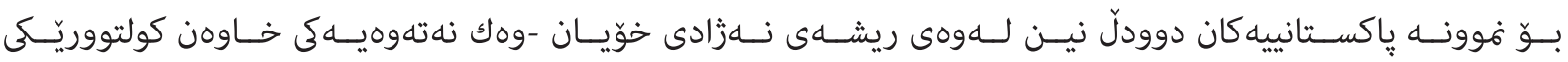

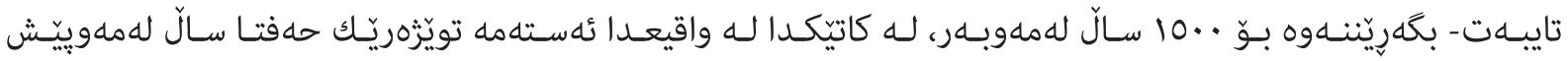

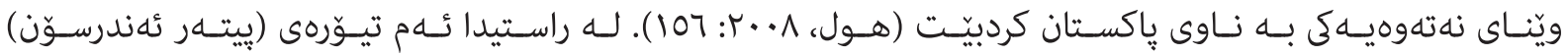

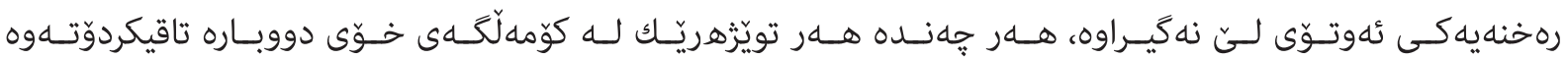

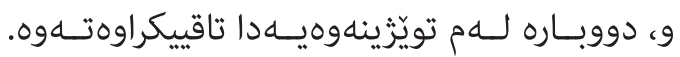

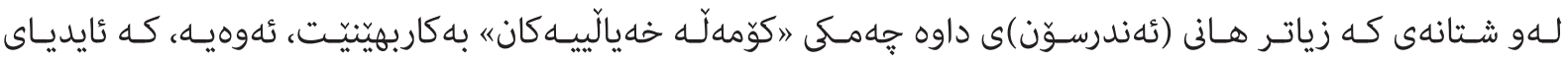

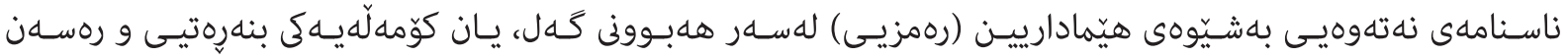

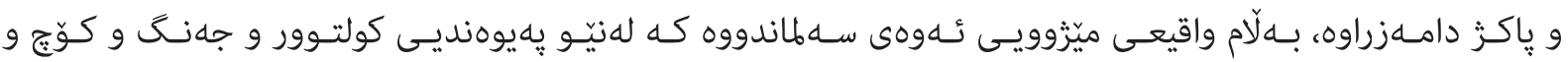

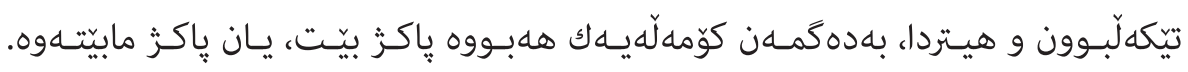
ميتودوَلِّزَياى تويَزَينهوهكه

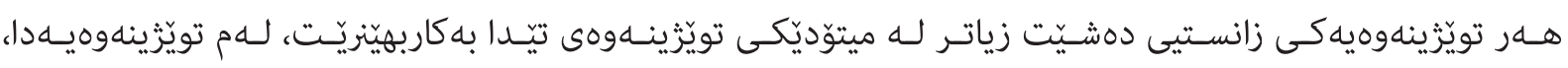

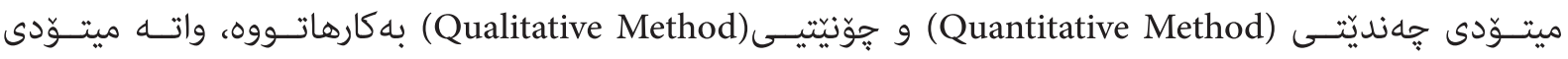

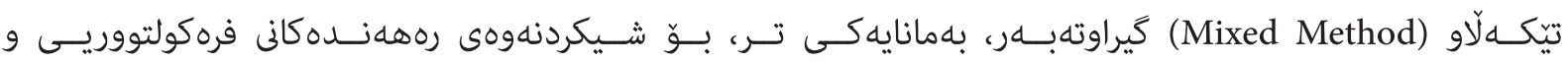

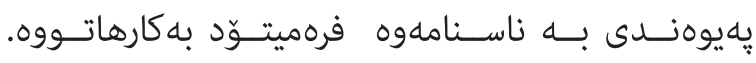

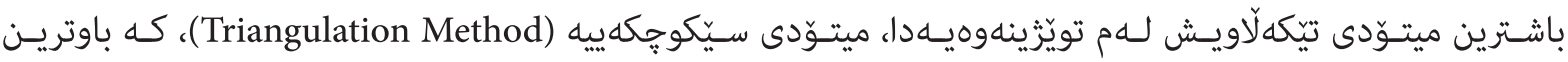

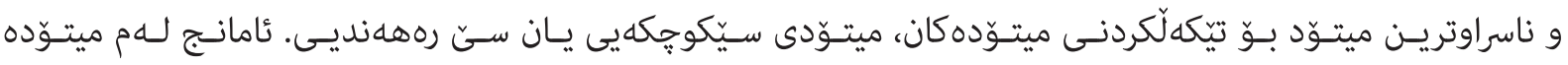

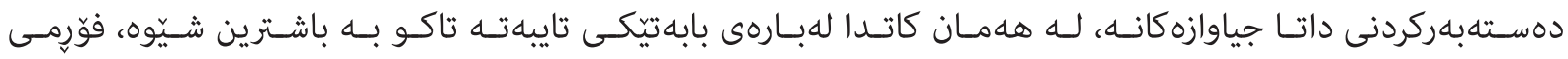

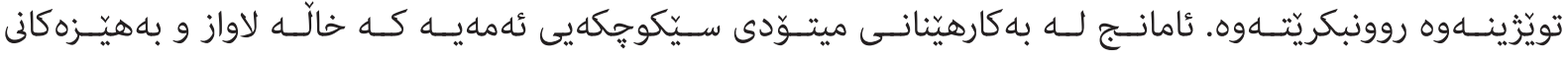

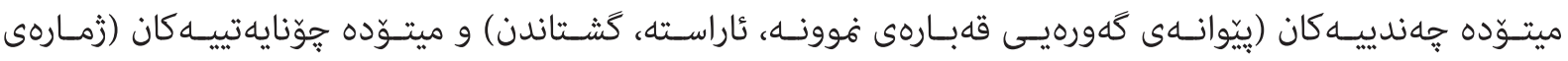

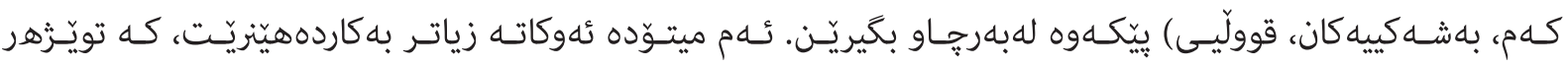

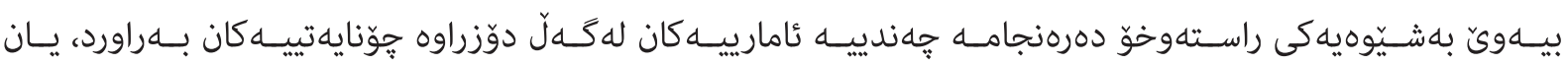

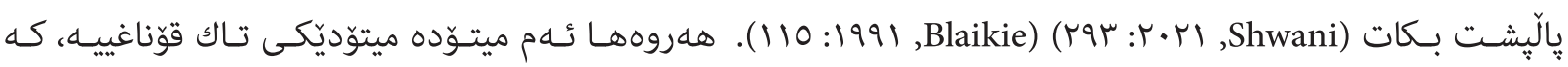

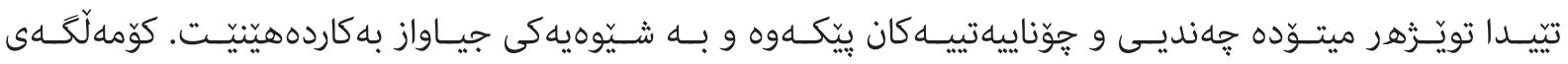

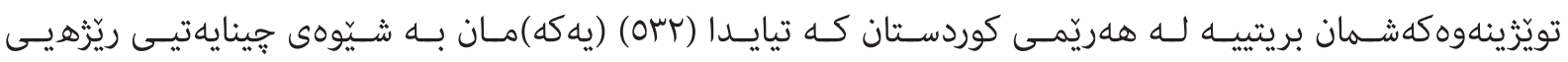
هـلَّبـرزاردووها.

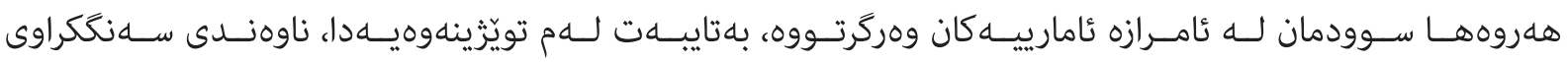

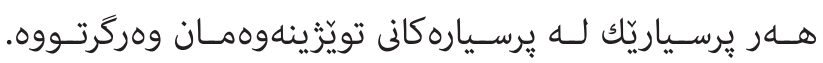

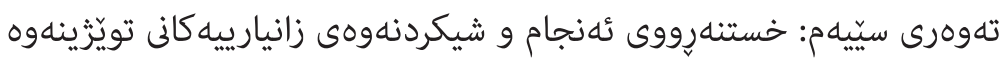

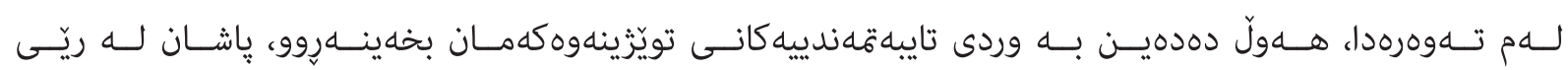


بله كارهيّنانـى هاوكيّشـهـ ئامارييهكانـهوه كاريكهرييه كانـى رهههنـدى ناسـنامه و زمــان بهسـهـر فرهولتووريـى دا

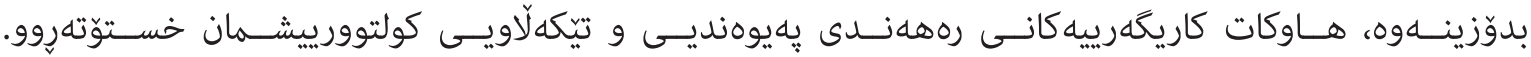
يهكه: تايبهتهندييهكانى نموونهى تويَزَينهوه

خشتهى (1) تايبهتهندييهكانى نموونهى تويَزْينهوهك دمخاتهروو

\begin{tabular}{|c|c|c|c|c|}
\hline$\%$ & زماره & & & \multirow{3}{*}{1} \\
\hline $61.0 \%$ & 326 & نيّر & \multirow{2}{*}{ رهكهز } & \\
\hline $39.0 \%$ & 208 & ميلي & & \\
\hline $30.7 \%$ & 164 & $18-27$ & \multirow{5}{*}{ ت تهمهن } & \multirow{5}{*}{ r } \\
\hline $31.8 \%$ & 170 & 28-37 & & \\
\hline $21.2 \%$ & 113 & $38-47$ & & \\
\hline $9.6 \%$ & 51 & $48-57$ & & \\
\hline $6.7 \%$ & 36 & $58+$ & & \\
\hline $1.1 \%$ & 6 & نهخويِندهوار & \multirow{7}{*}{ ثاستى خويَتدن } & \multirow{7}{*}{ r } \\
\hline $5.6 \%$ & 30 & سـرهتايي & & \\
\hline $8.2 \%$ & 44 & ناوهنديى & & \\
\hline $13.1 \%$ & 70 & ئامادهيى & & \\
\hline $18.4 \%$ & 98 & טِايمانكَه & & \\
\hline $45.3 \%$ & 242 & زانكو & & \\
\hline $8.2 \%$ & 44 & خويَتدنى بالاً & & \\
\hline $0.7 \%$ & 4 & زوقر خرابٍ & \multirow{5}{*}{ بارى ثُابوورى } & \multirow{5}{*}{$\varepsilon$} \\
\hline $5.1 \%$ & 27 & خرابٍ & & \\
\hline $63.3 \%$ & 338 & مامناوهند & & \\
\hline $27.7 \%$ & 148 & باش & & \\
\hline $3.2 \%$ & 17 & زوّرباش & & \\
\hline
\end{tabular}




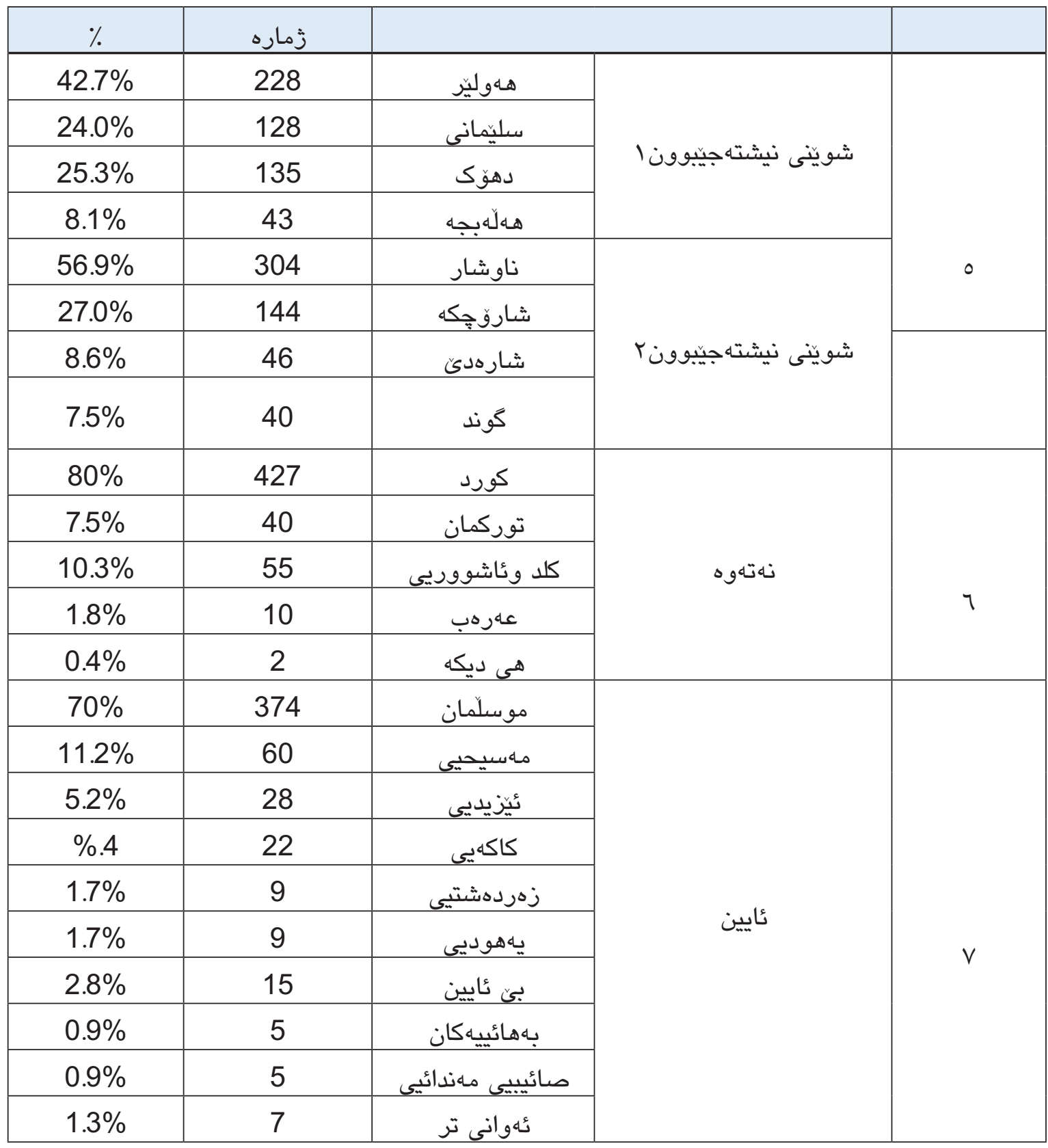

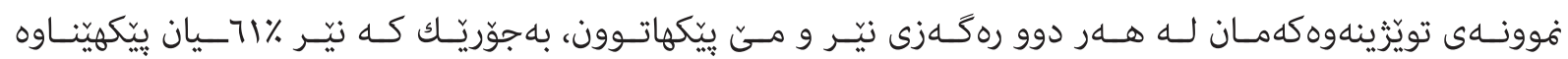

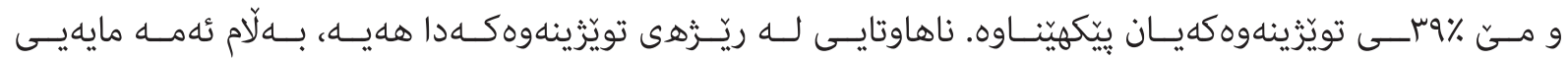

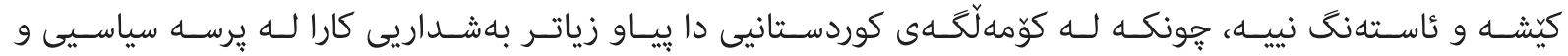

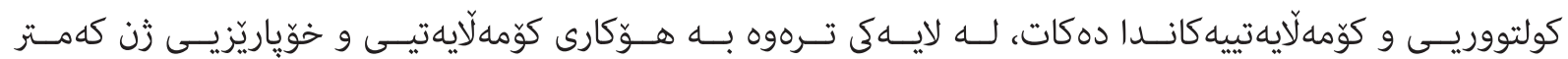

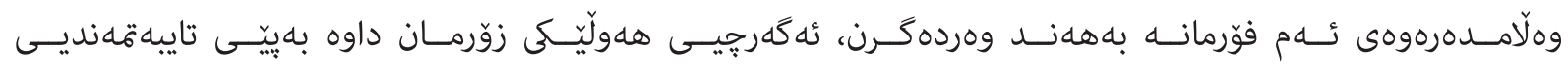

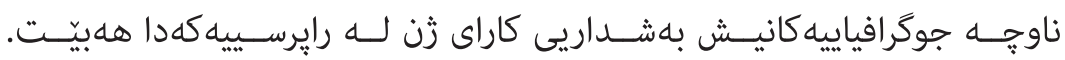

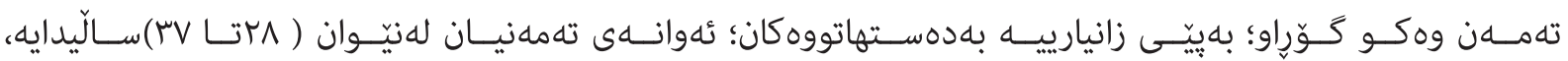

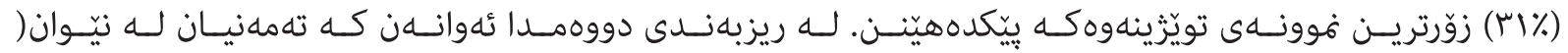

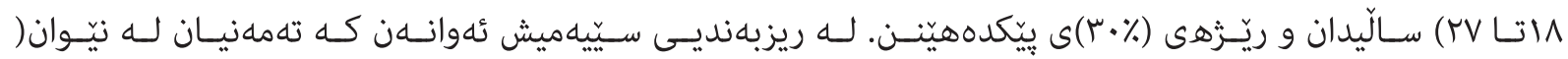

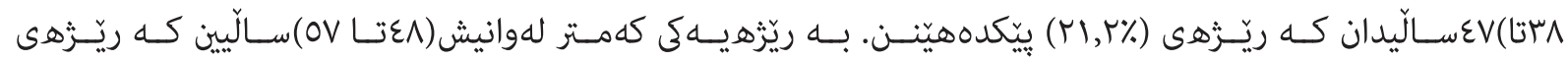


6

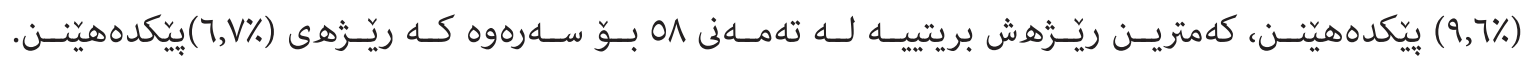

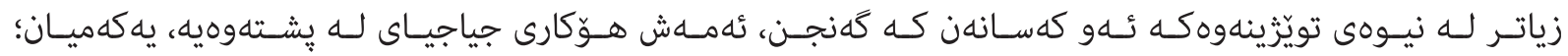

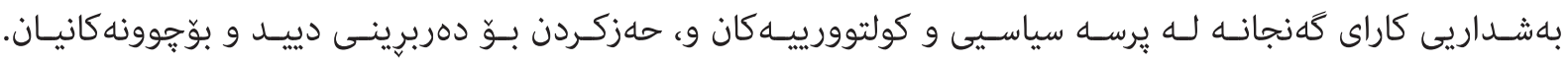

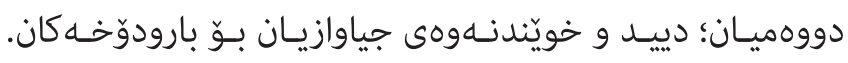

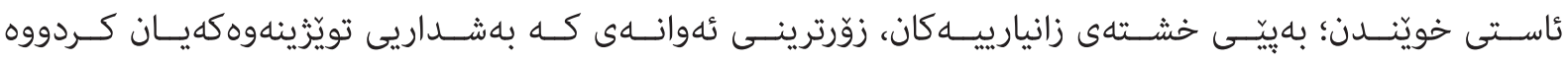

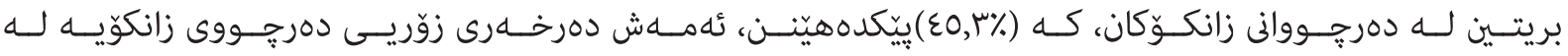

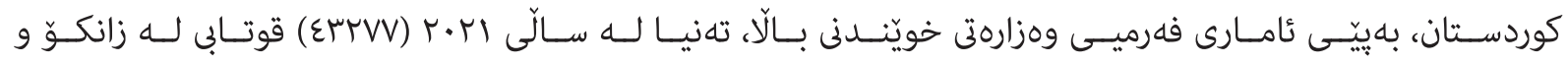

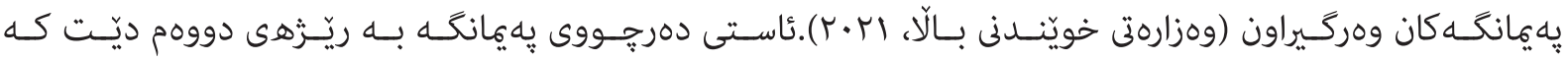

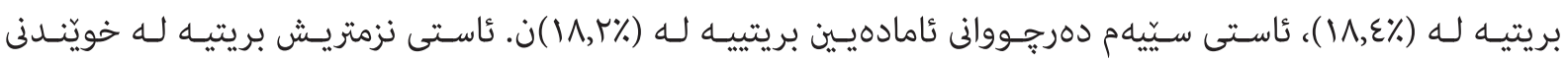

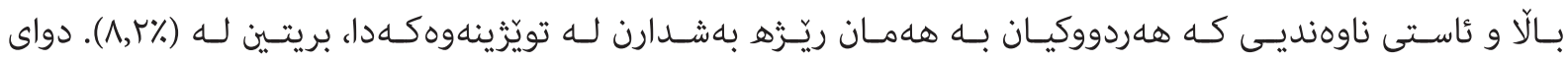

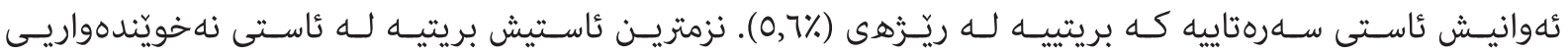
كـه ريّزهوكـهى بريتيـه لـه (1) (1, ).

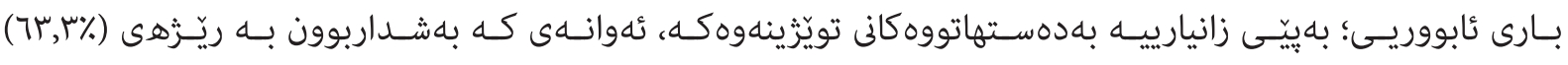

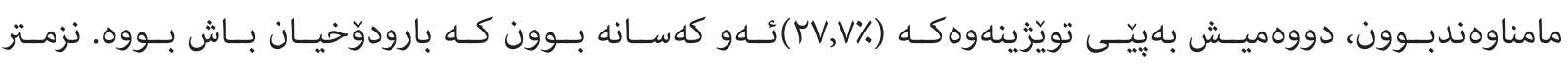

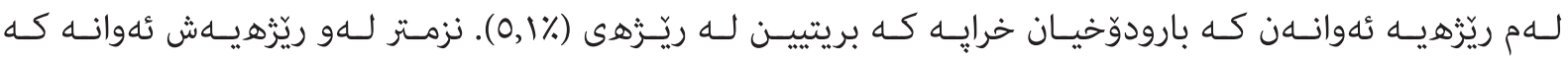

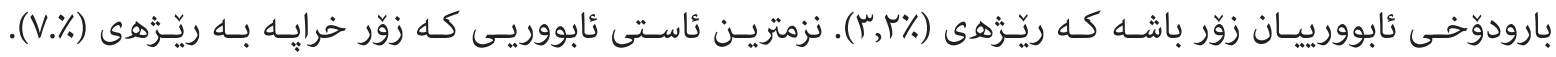

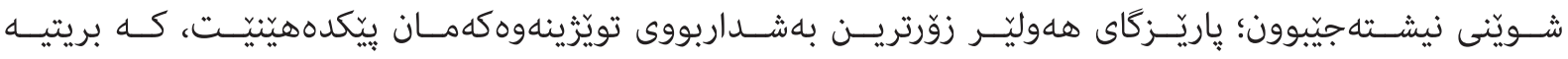

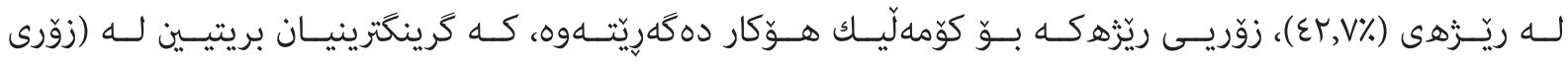

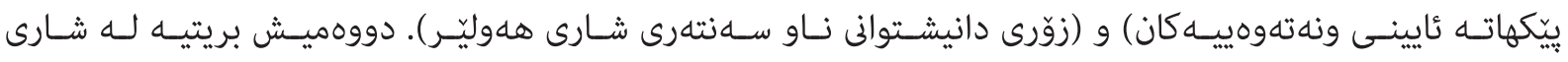

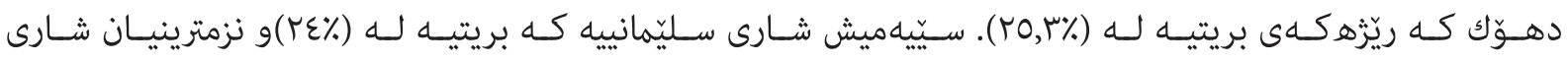

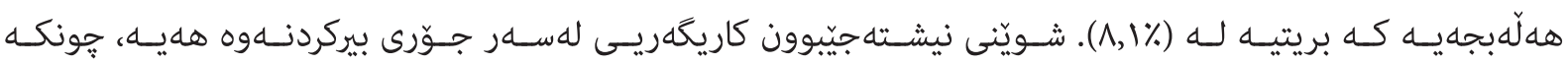

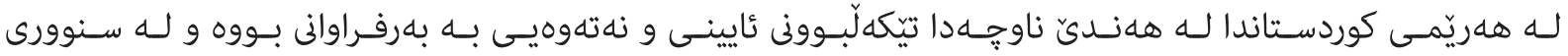

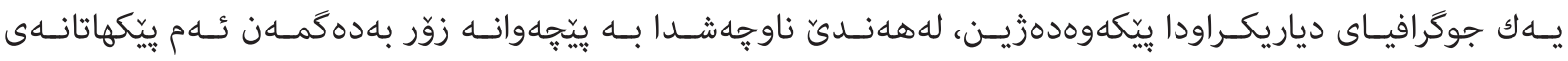

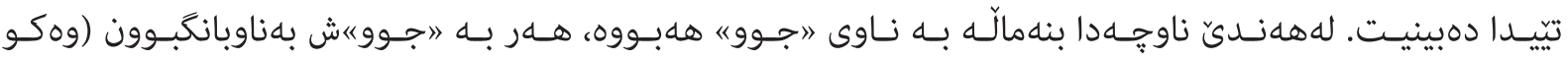

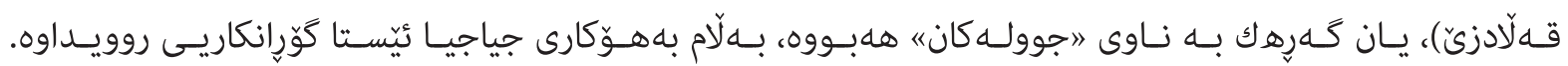

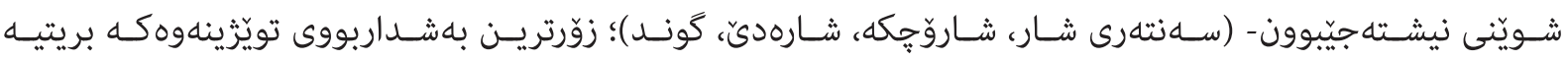

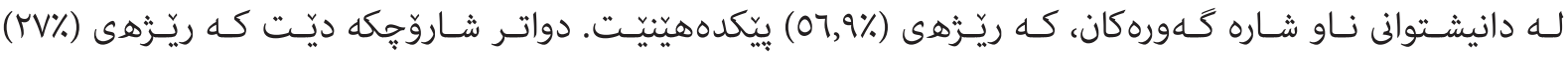

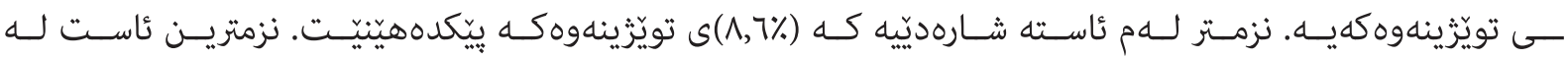

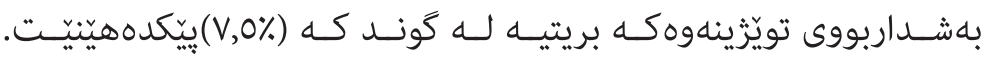

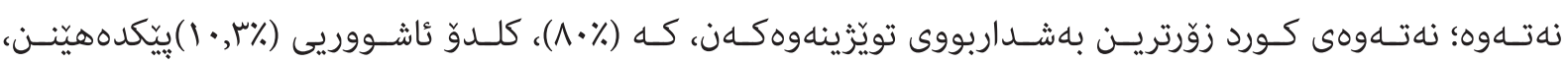

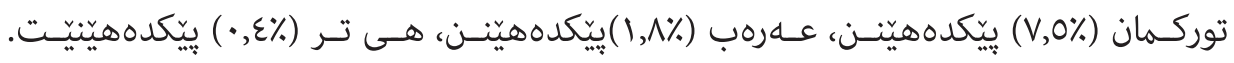

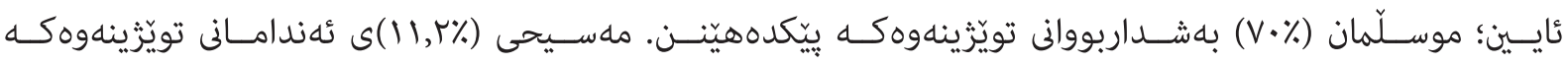

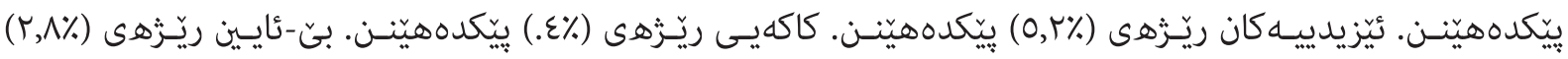




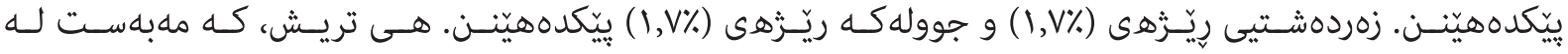

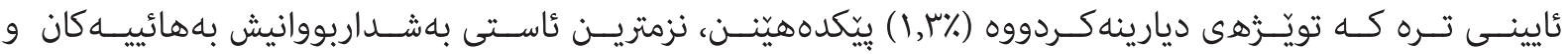

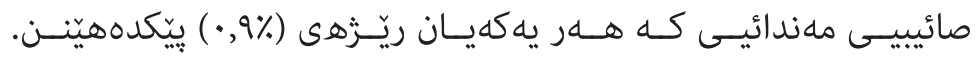

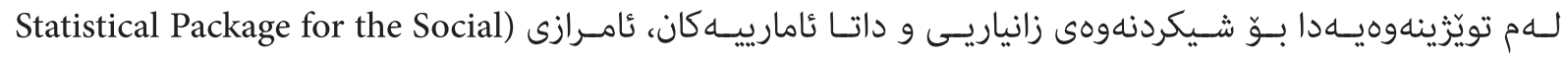

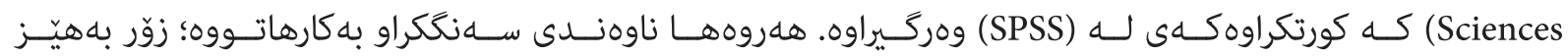

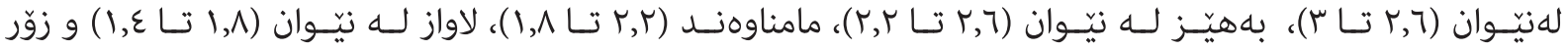
لاواز لـه نيّوان (ع,ا تـا ا)ــه.

\section{دووهم: كاريكهريى ناسنامه و زمان لهسهر فرهكولتووريى}

خشتهى (r) كاريكهريى ناسنامه و زمان للههر فرهولتووريى دهخاتهروو

\begin{tabular}{|c|c|c|c|}
\hline$=\frac{\sqrt{3}}{3} \frac{\sqrt[3]{3}}{3}$ & 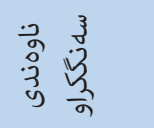 & يرسيار & رهos \\
\hline$\% \wedge 9$ & r,VA & باوهرت بـه ياراستني مافي نهتهوهكاني تر هـهيه؟ & \multirow{9}{*}{ 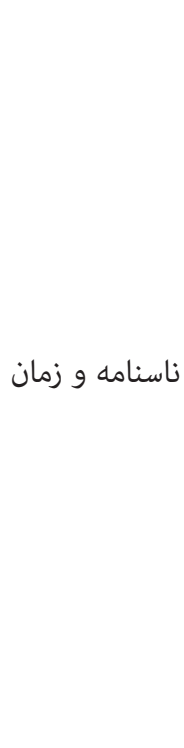 } \\
\hline$\% \wedge 7$ & Y,VY & عايا شـانازى بـ ناسنامهى نهتهوهكهت دهكهيت؟ & \\
\hline$\% 91$ & r,AY & ئايا باوهرت به بِيكاهوهزيانى نهتهوهيى هـيه؟ & \\
\hline$\%$ \% , o & 2.05 & 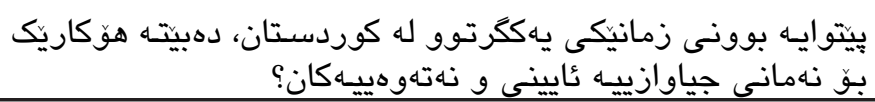 & \\
\hline$\%$ & 2.68 & 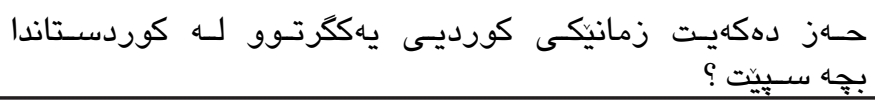 & \\
\hline$\% \vee r, 0$ & $Y, \varepsilon V$ & 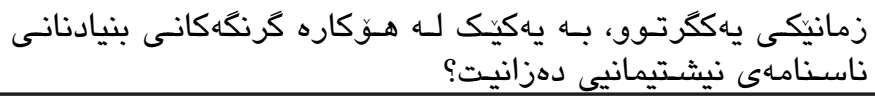 & \\
\hline$\% 9 \cdot, 0$ & Y,A & ئايا هـه ركيز هـهولتّداوه فيّرى زمانى نهتهوهكانى تر بيت؟ & \\
\hline$\% 9 r, 0$ & 2.85 & 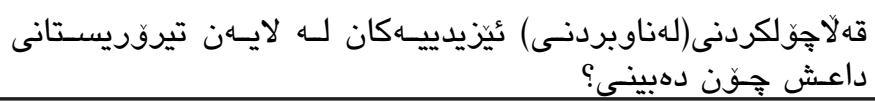 & \\
\hline$\%$ & 2.88 & كاردساتى شنكال ع كاريكارييهكى لهسهرت هـهبوو؟ & \\
\hline
\end{tabular}

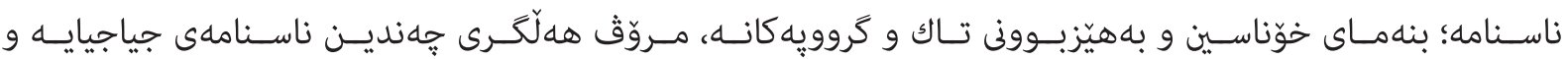

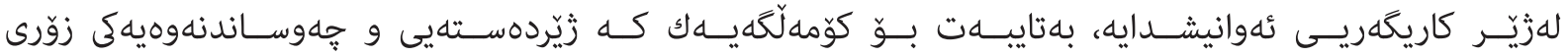

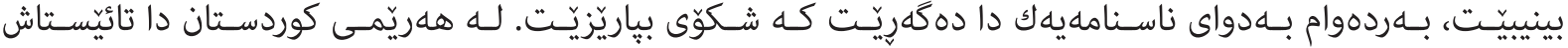

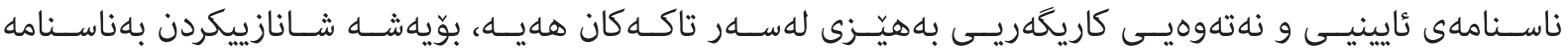

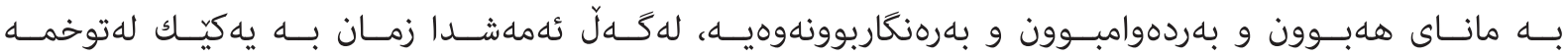

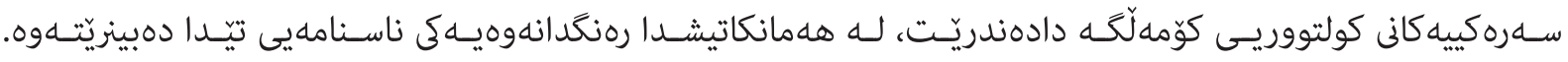

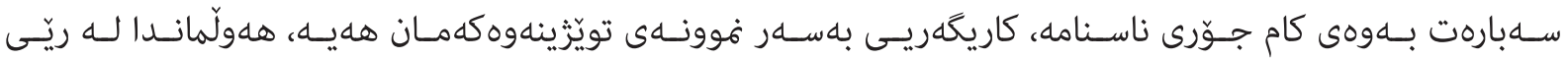

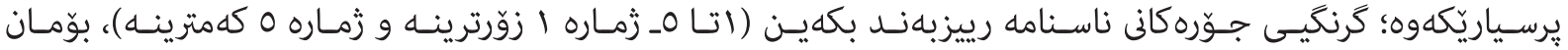




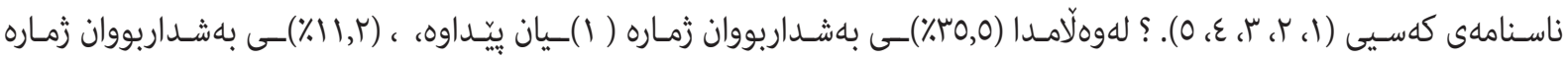
(0) يان يِّداوه.

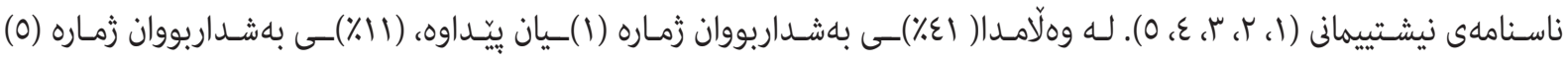
سيان يِيّداوه.

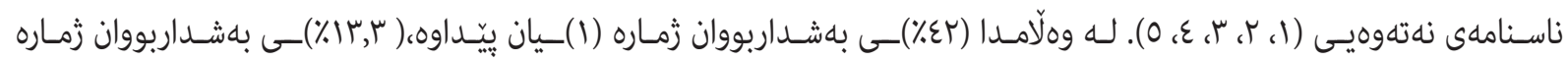
(0) سيان يِّداوه.

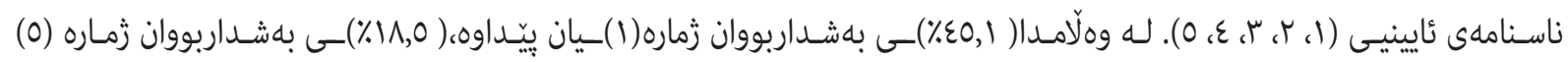
سيان يِيّداوه.

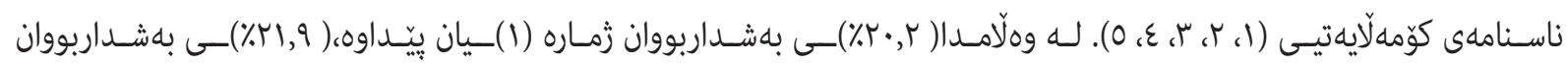
زمـاره (0)سيان يَّـداوه.

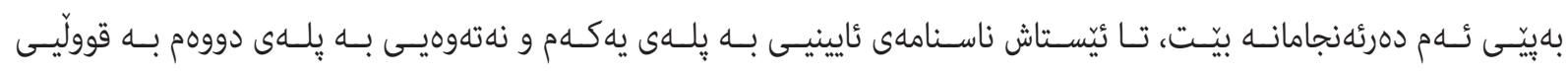

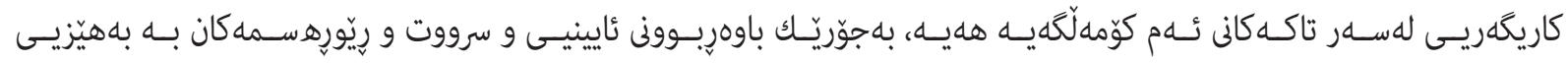

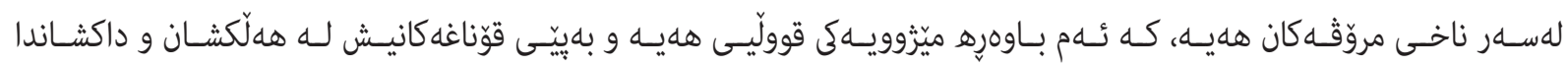

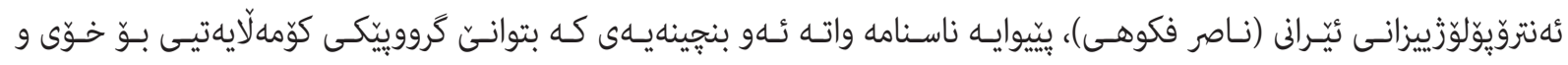

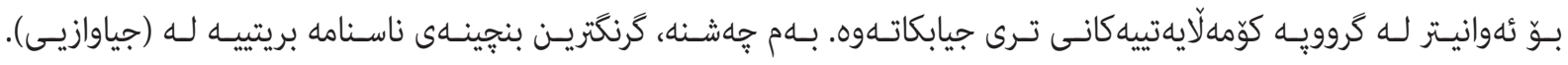

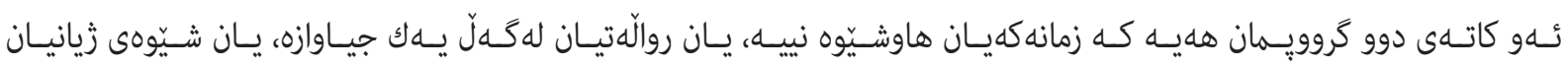

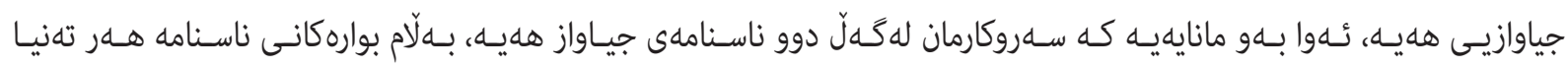

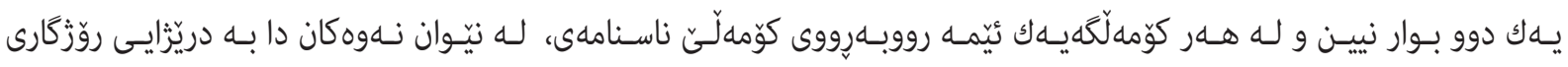

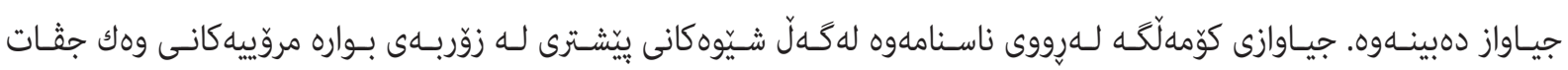

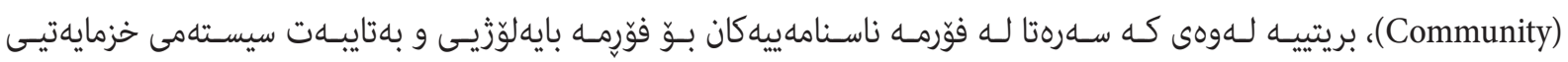

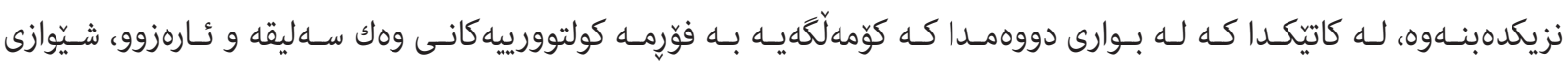

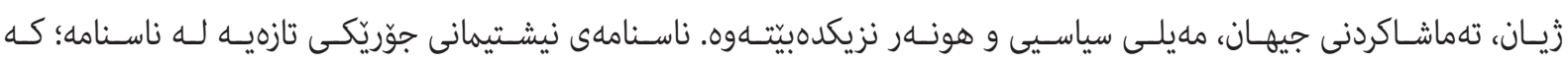

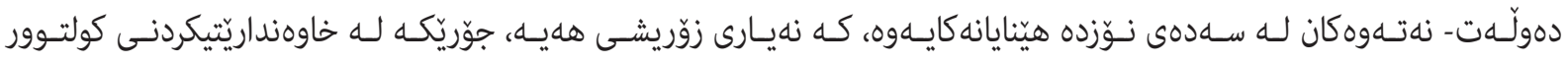

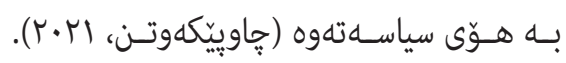

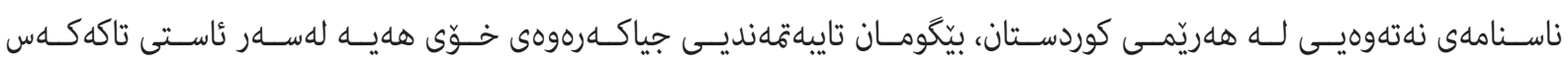

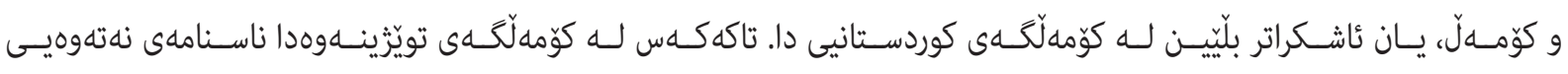

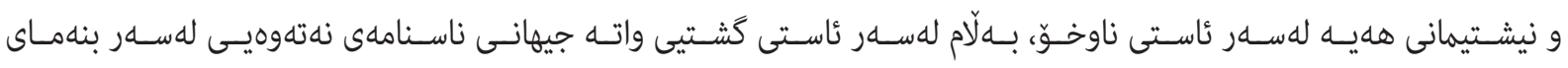

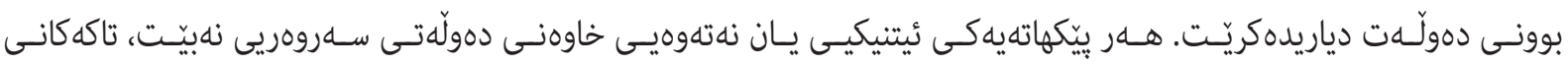

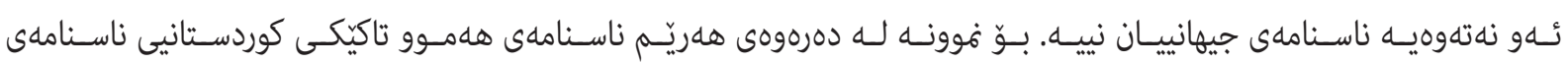

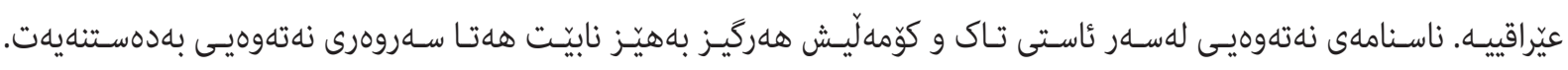

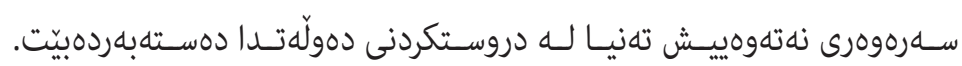

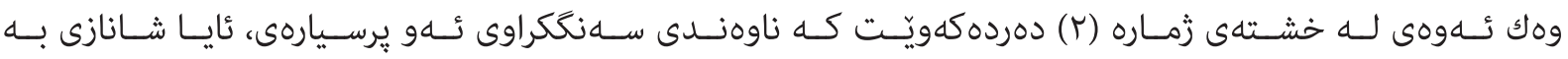




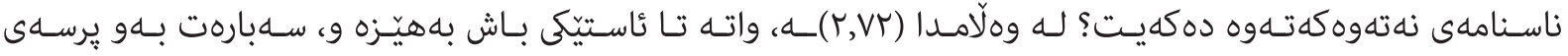

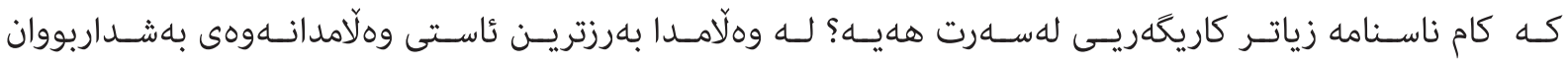

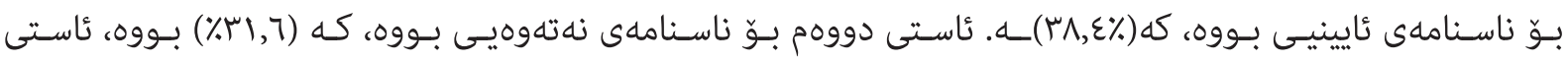

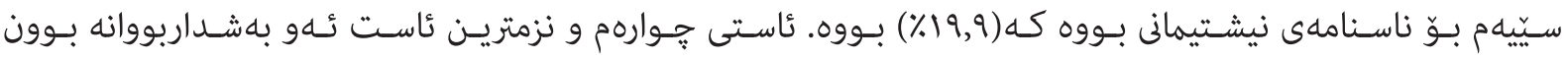

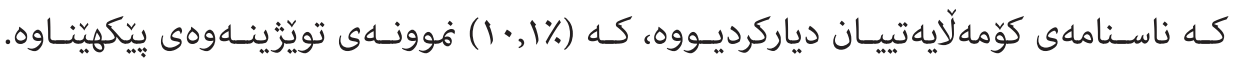

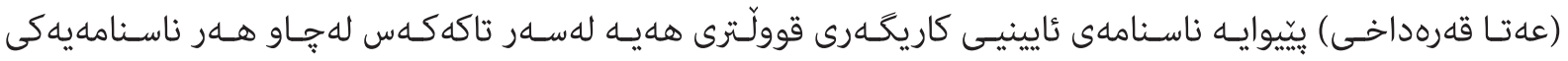

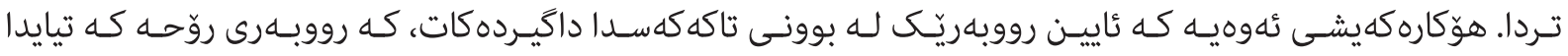

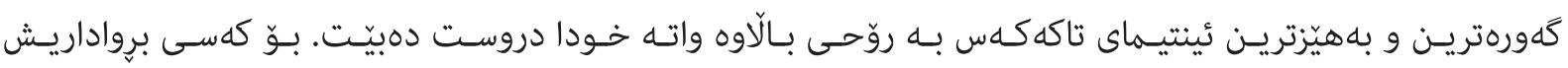

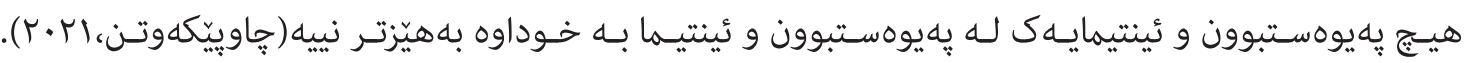

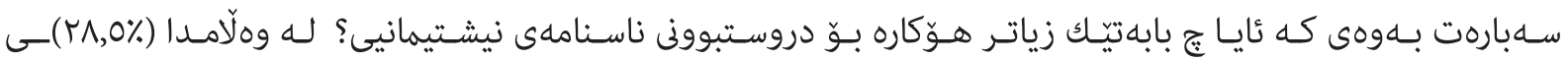

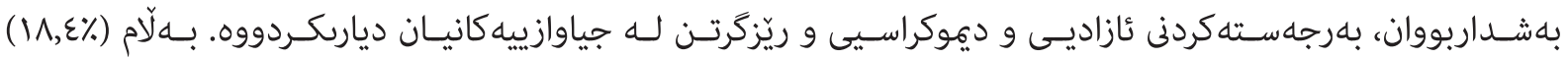

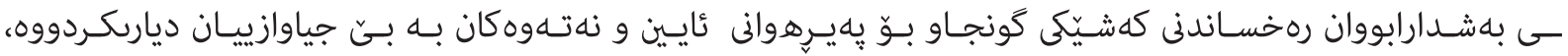

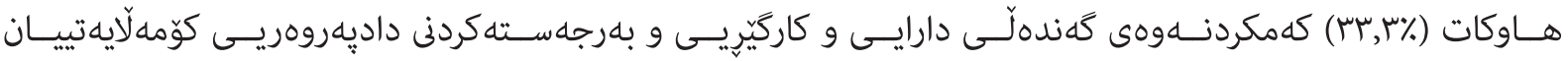

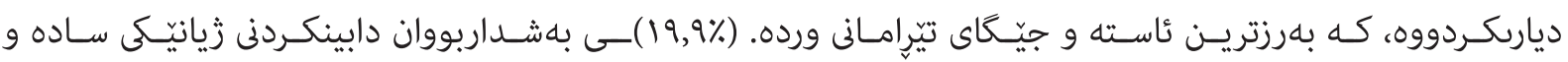

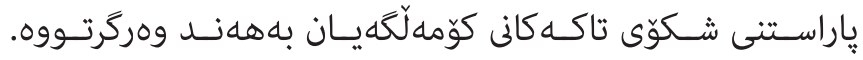

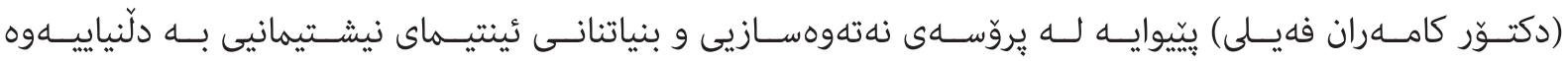

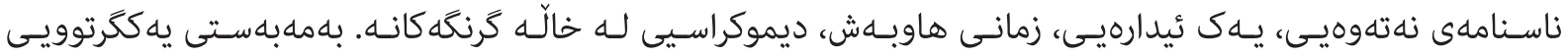

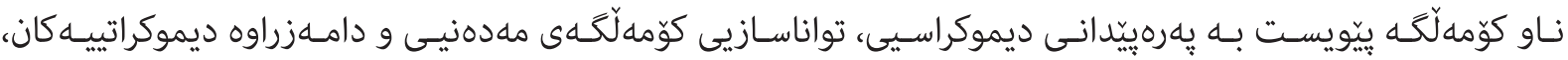

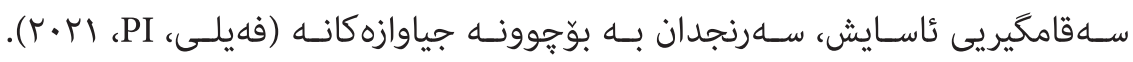

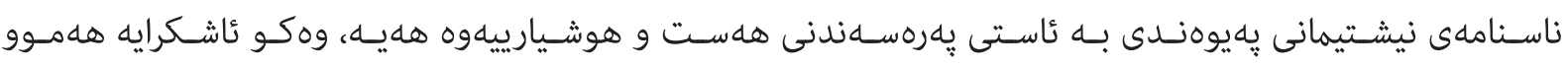

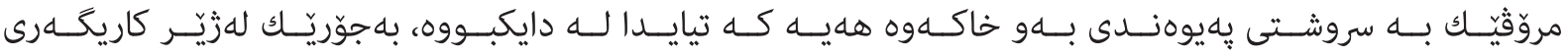

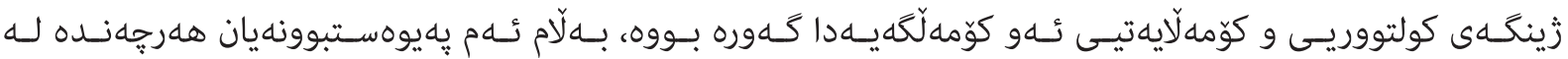

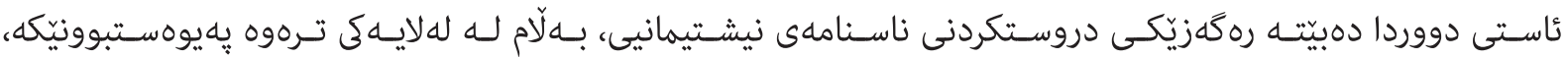

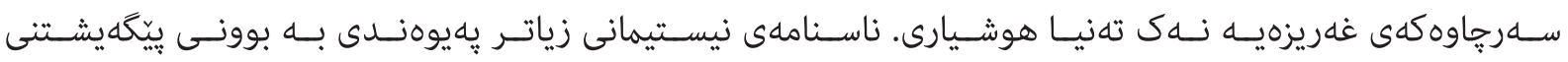

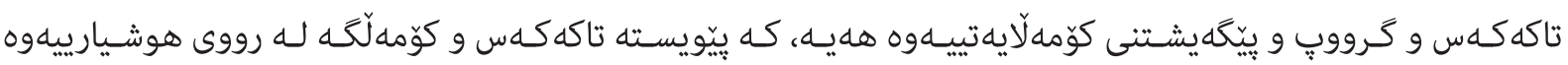

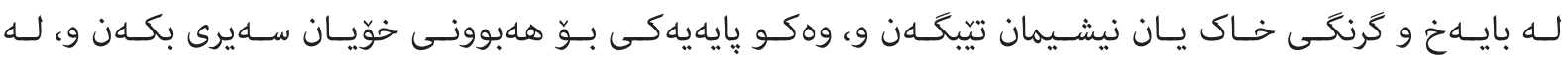

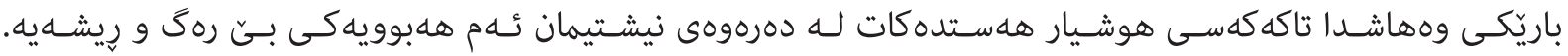

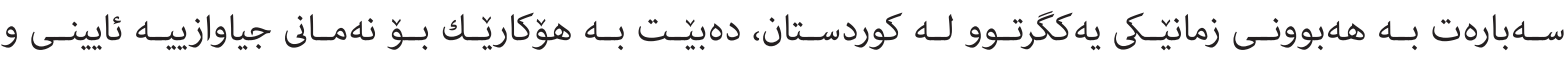

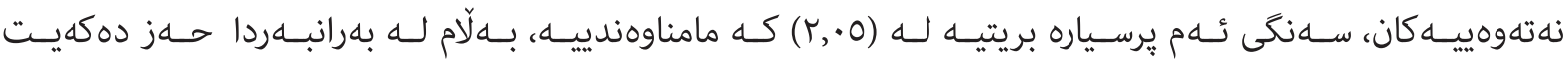

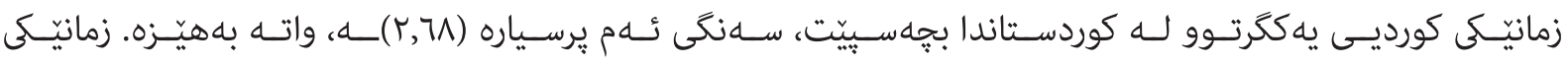

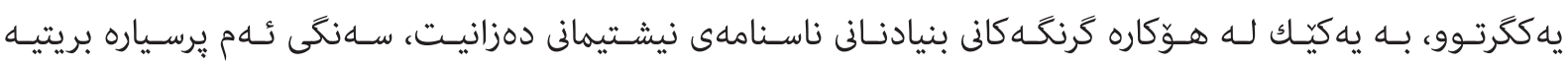

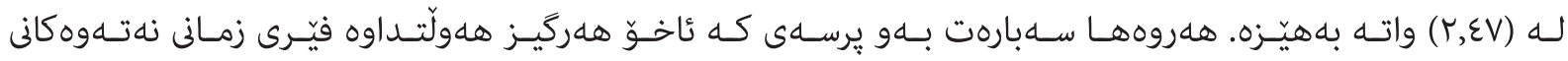

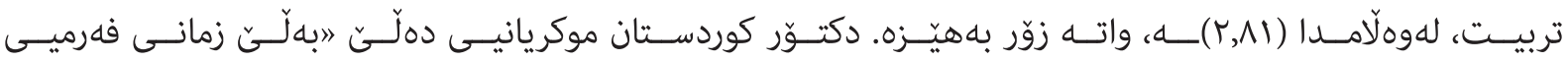




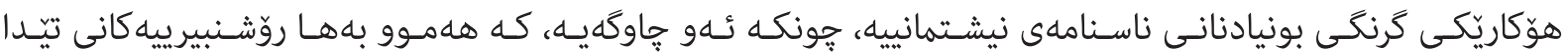

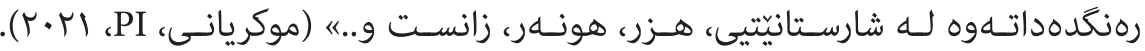

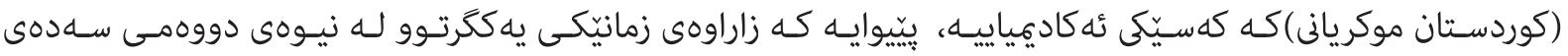

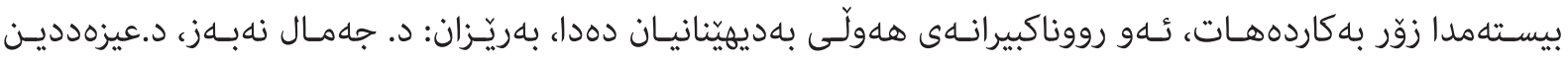

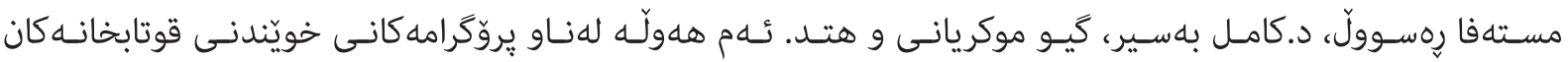

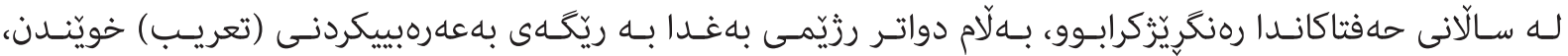

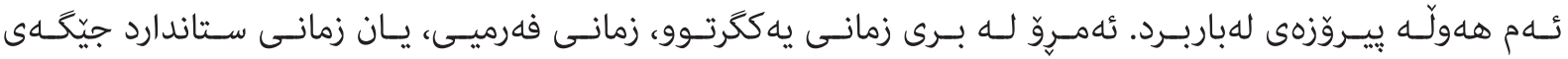

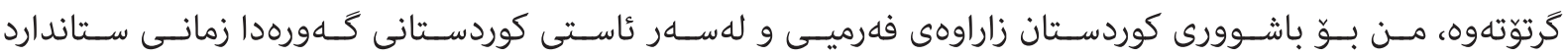

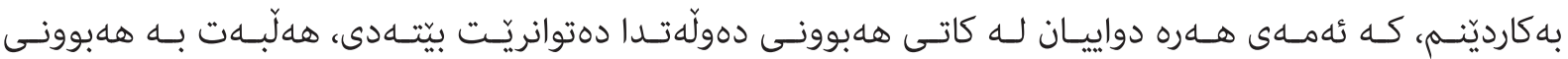

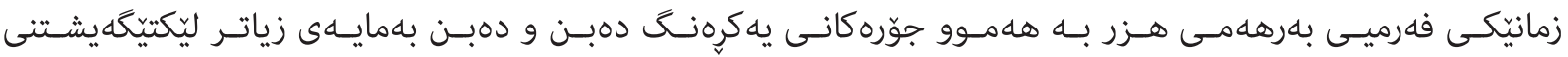

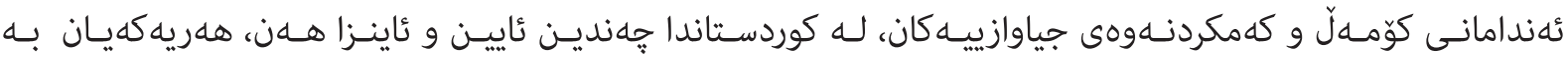

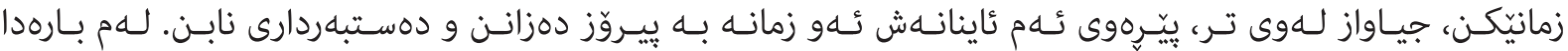

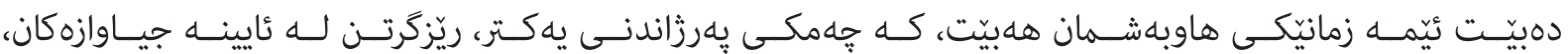

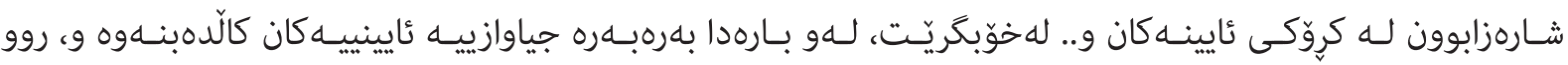

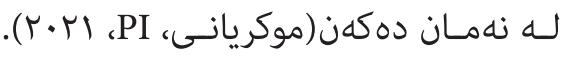

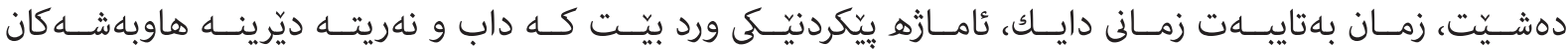

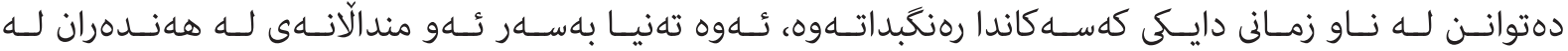

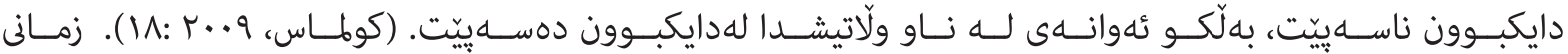

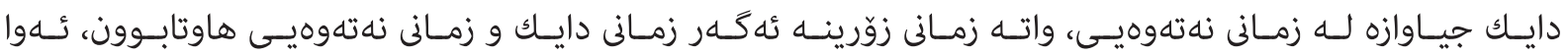

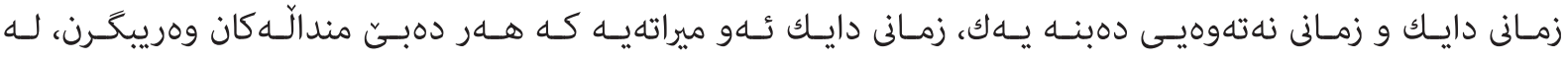

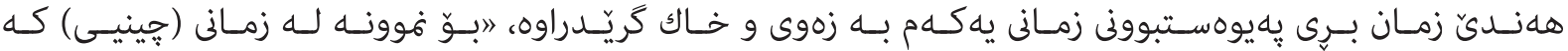

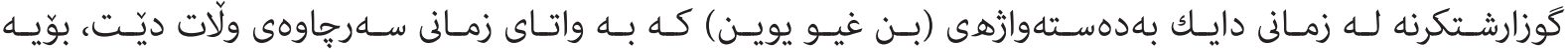

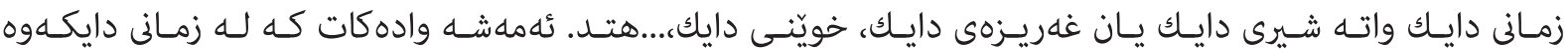

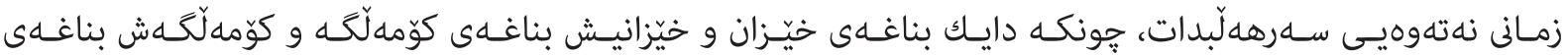

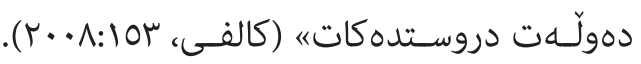

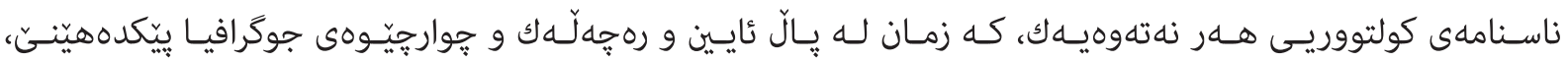

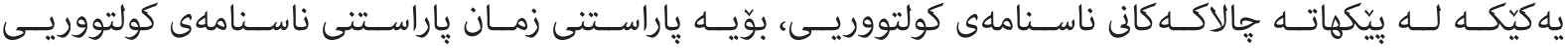

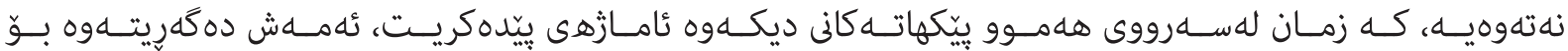

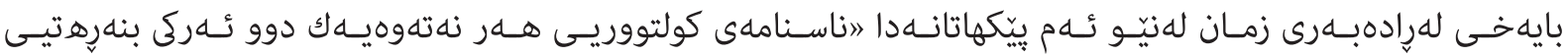

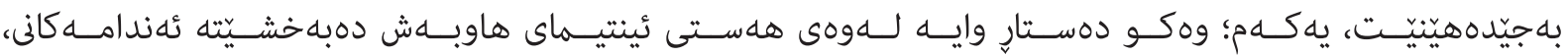

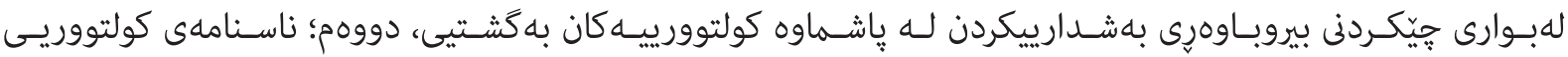

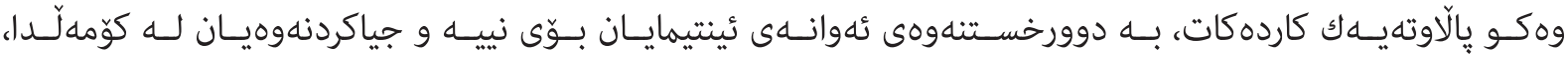

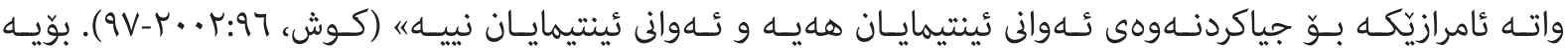




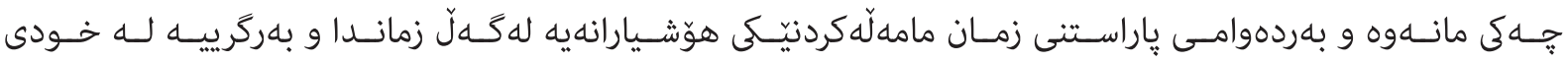

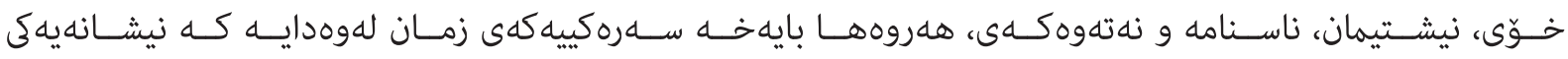

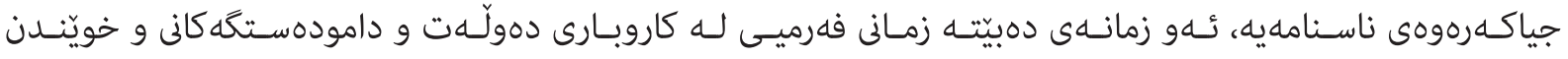

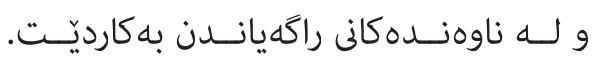

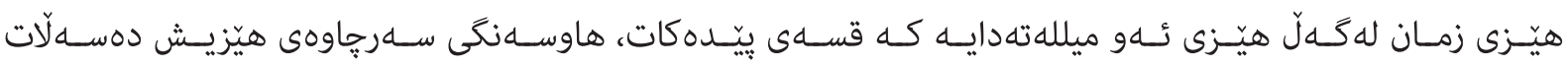

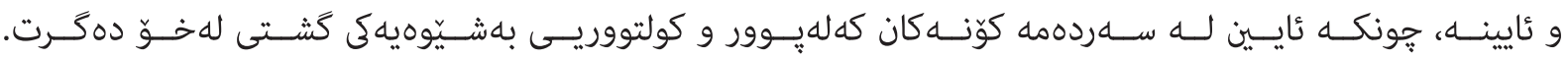

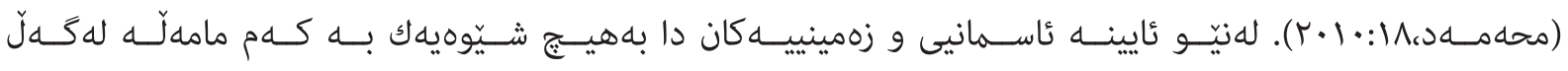

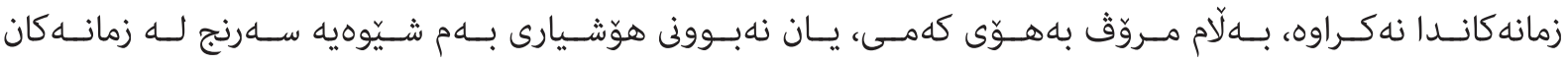

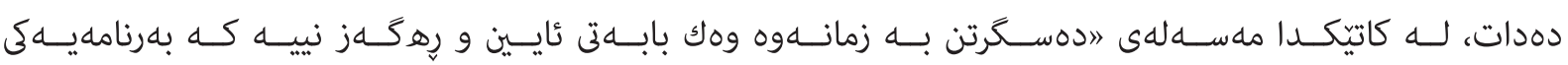

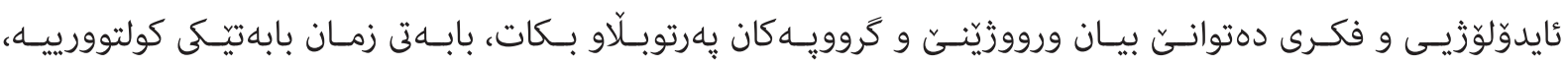

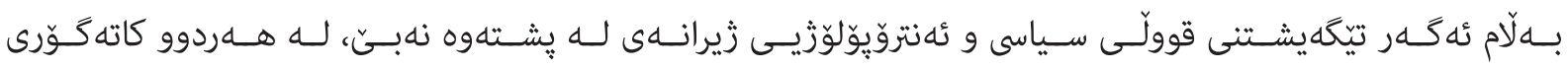

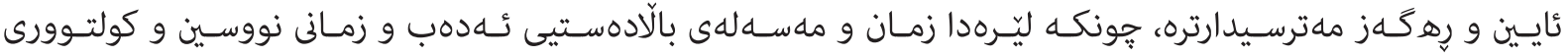

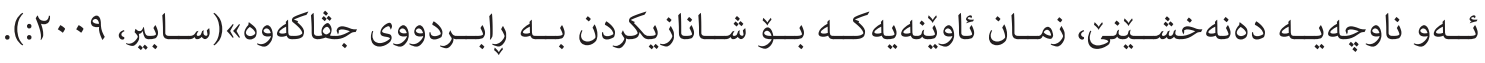

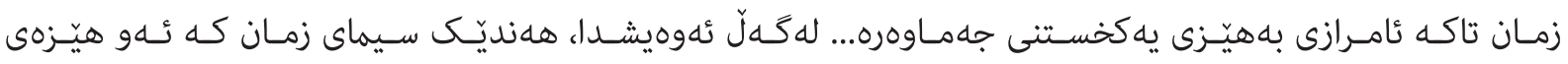

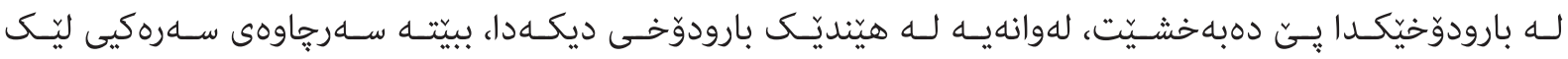

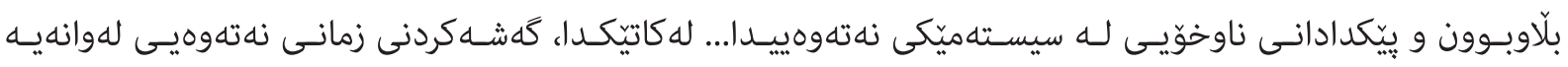

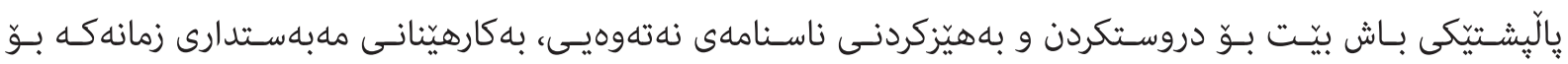

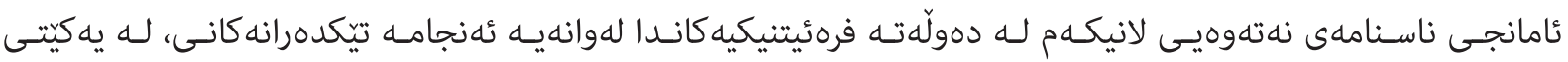

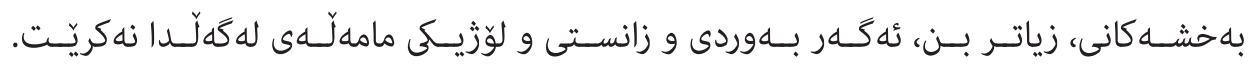

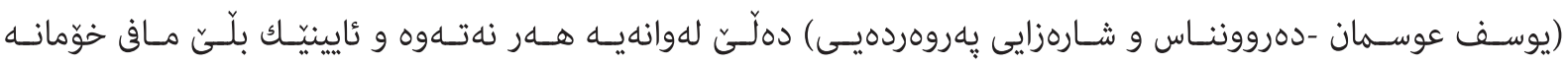

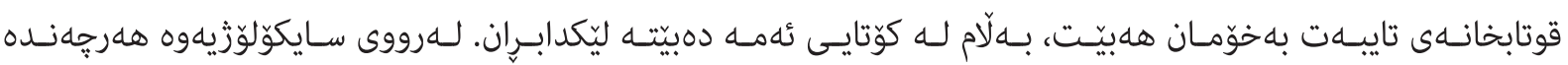

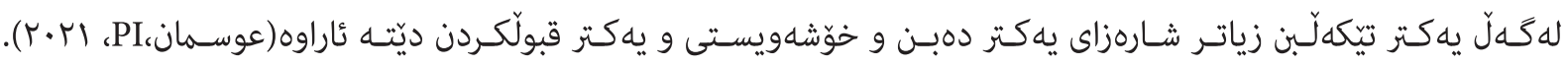

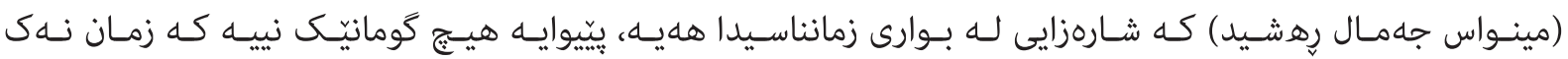

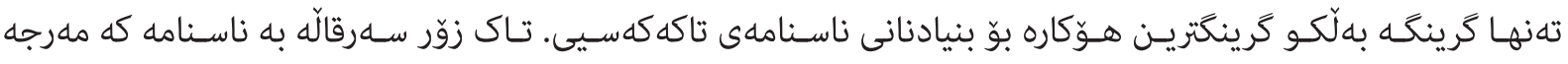

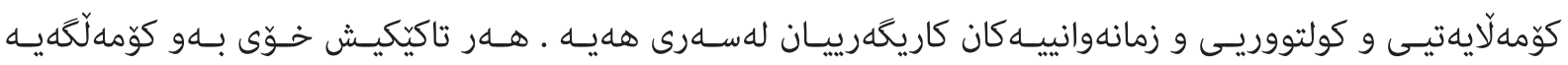

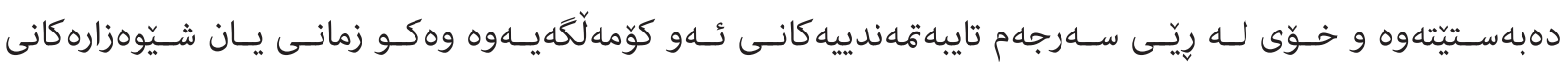

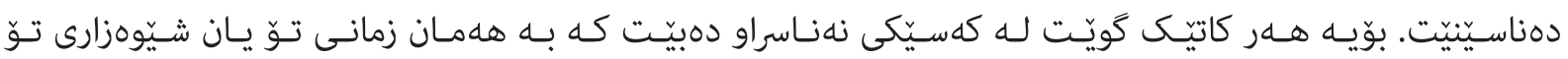

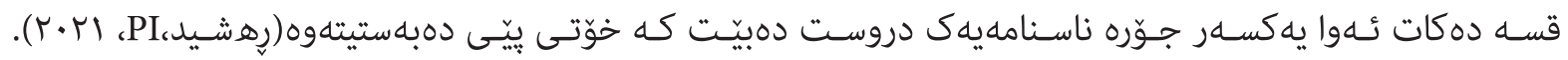

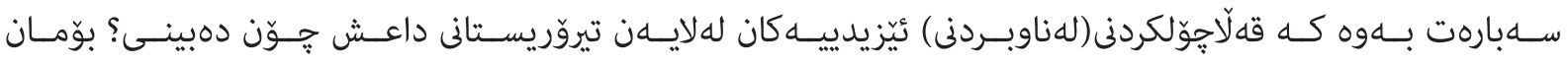

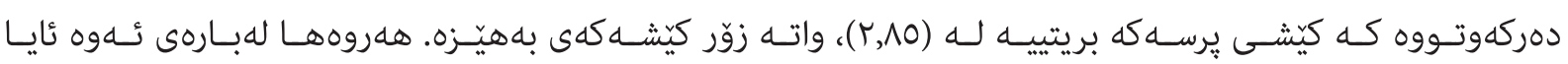

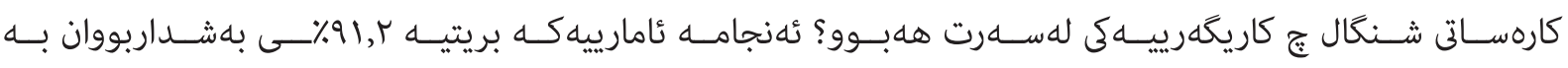

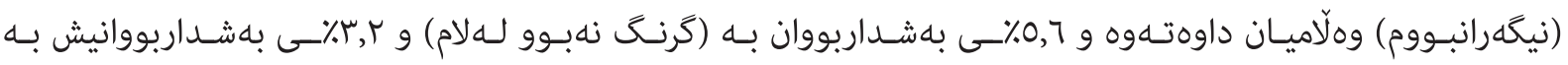

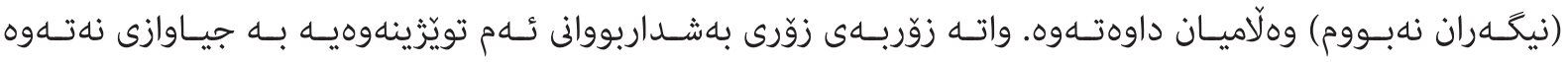




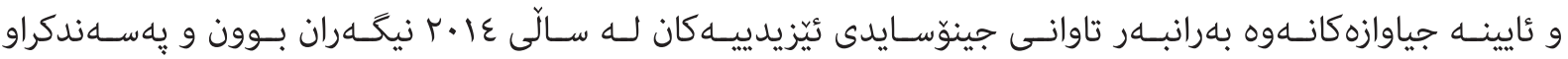

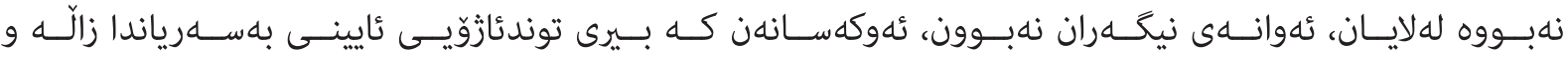

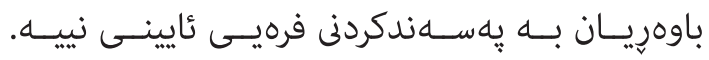

\section{سيّيهم: كاريكهريى يَهيوهنديى و تيّكهلآويى كولتووريى الهسهر فرهكولتووريى}

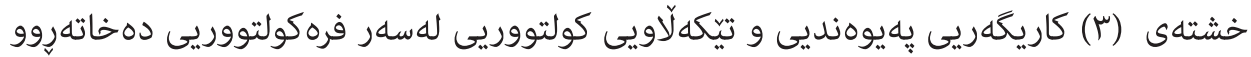

\begin{tabular}{|c|c|c|c|}
\hline 类步 & 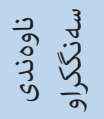 & يرسيار & رهه هلد \\
\hline$\% \wedge \vee, 0$ & 2.75 & كئايا باوهرت به بيّكهوهزيانى نيّوان نهتهوه و كولتووره جياوازهكان هـيه؟ & \multirow{22}{*}{ 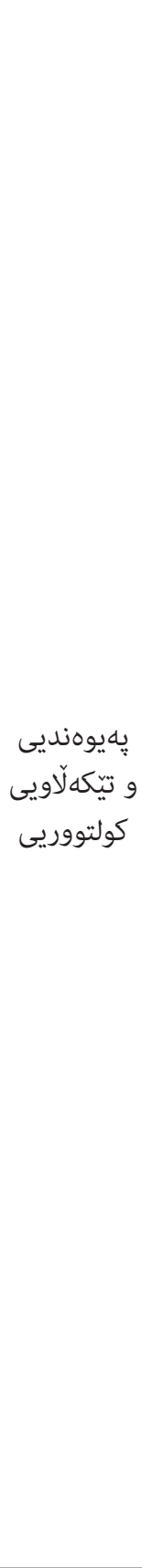 } \\
\hline$\%$ \% & 2.44 & 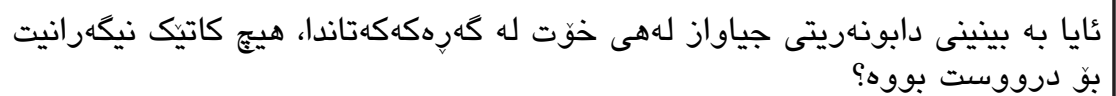 & \\
\hline$\% \wedge 9$ & 2.78 & عايا ريّز له ريّورهسم و سرووتى نايين و نهتهوهكانى تر دهكريت؟ & \\
\hline$\% \varepsilon\urcorner, 0$ & 1,94 & كأيا باوهرت به كردهى هاوسهركيريى له كهل كهسيكدا ههيه، كه له ئايينى خوّت نهييت؟ & \\
\hline$\%$ or & 2.06 & 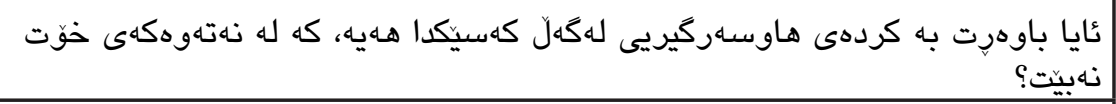 & \\
\hline$\% 19,0$ & 1.39 & 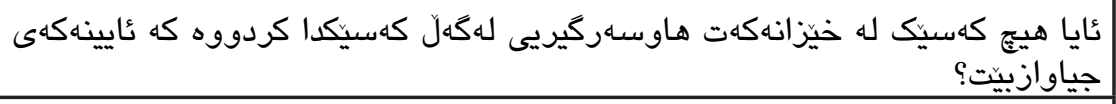 & \\
\hline$\%$ ro & $1, \mathrm{~V} \cdot$ & 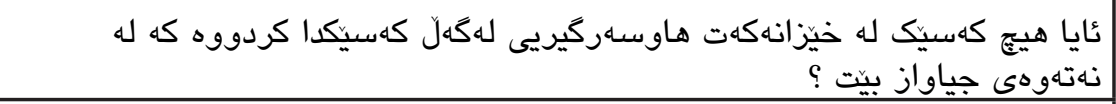 & \\
\hline$\%$ \% r,o & 2.07 & ئايا سهردانى شوينّه بيروز كانى ئايينهانى ديكهت كردووه؟ & \\
\hline$\% 91$ & 2.82 & 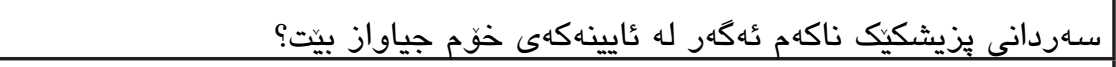 & \\
\hline$\% 9 \%, 0$ & 2.87 & سهردانى بِيشكيك ناكهم ئهكَر له نهتهوهكهى خُوم جياواز بيّت؟ & \\
\hline$\% \wedge 9$ & 2.78 & خهمبار نابم ئهذه يِيّرهوانى ئايينهكانى ديكه دووجارى كارهسات بينهوه؟ & \\
\hline$\%$. & r,A. & خهمبار نابم ئهكهر بِيّرهوانى نهتهوهكانى ديكه دووجارى كارهسات بينهوه؟ & \\
\hline$\% 91$ & $r, \Lambda Y$ & 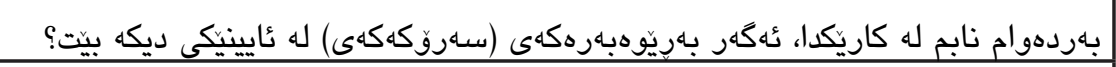 & \\
\hline$\%$. & r,A. & بهردهوام نابم له كاريكدا، ئهكهر بهريّوهبهرهكهى (سهوركهكهى) له نهتهوهيهكى ديكه بيت؟؟ & \\
\hline$\% Y V, 0$ & 1,00 & 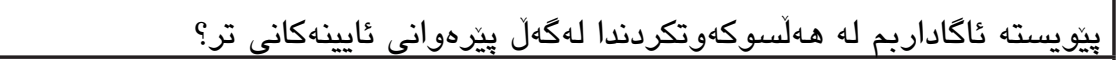 & \\
\hline$\%$. & 1,7 . & 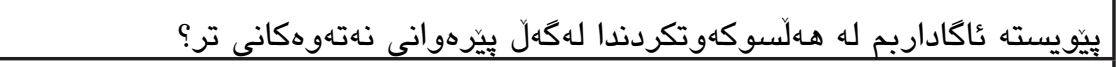 & \\
\hline$\% 07$ & r,IT & بهشدارى له بوّنه كولتوورييه جياوازييهكاندا دهكهيت؟ & \\
\hline$\% \vee\urcorner, 0$ & r,OV & به بينينى جلوبهركى كولتووره جياوازهكان دلّخوش دهبيت؟ & \\
\hline$\% \mathrm{VV}$ & $r, 0 \varepsilon$ & حهزدهكهيت خواردنى نهريته جياوازهكان بخويت و كرينكى بيّدهدهيت؟ & \\
\hline$\%$ & 2.63 & حهزدهكهيت پِيوهندى كومهلآيهتييت لهكهل كولتووره جياوازهكانى ديكهدا هـبيت؟؟ & \\
\hline$\% \wedge$ & $r, \mathrm{~V}$ & 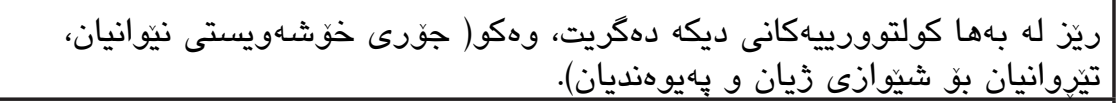 & \\
\hline$\%$ \%, 0 & r, Vo & 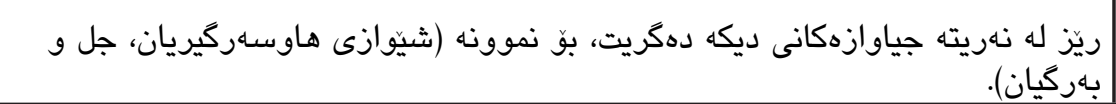 & \\
\hline
\end{tabular}




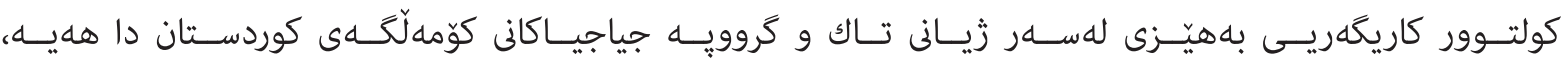

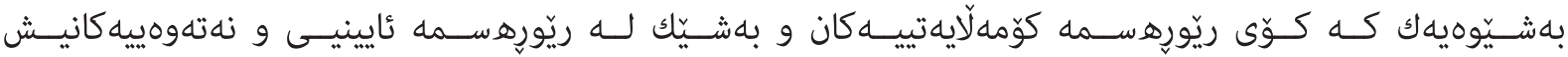

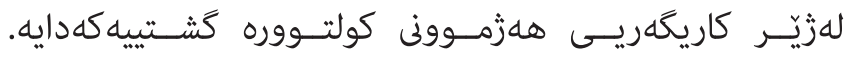

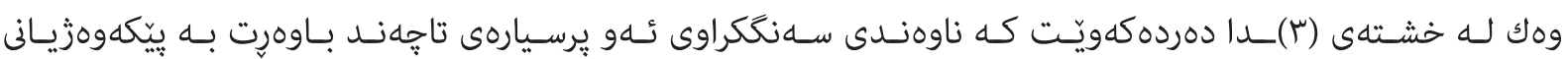

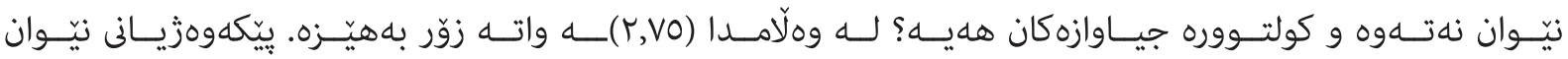

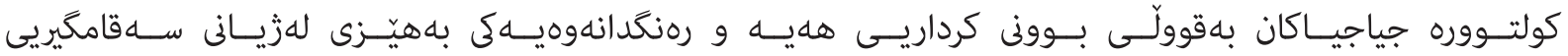

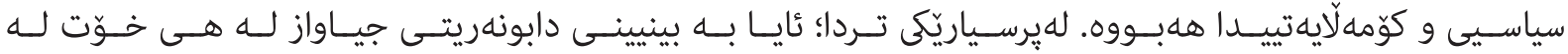

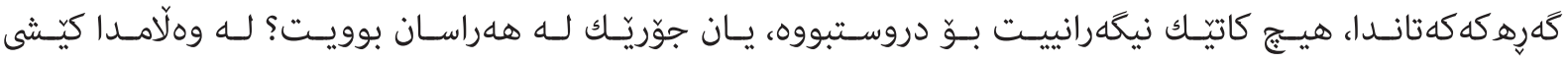

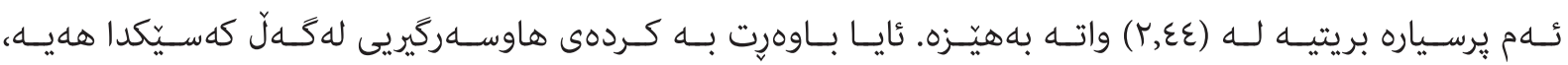

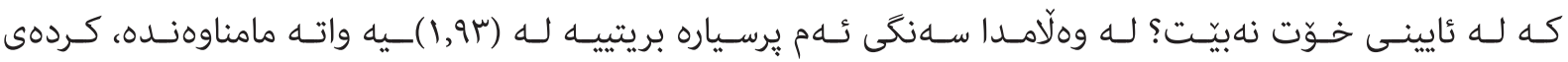

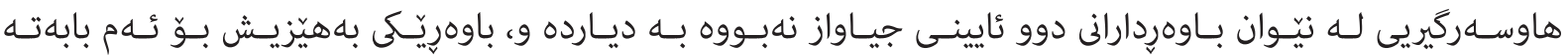

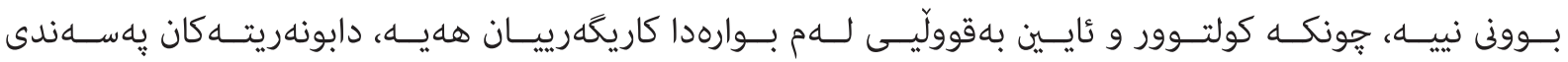

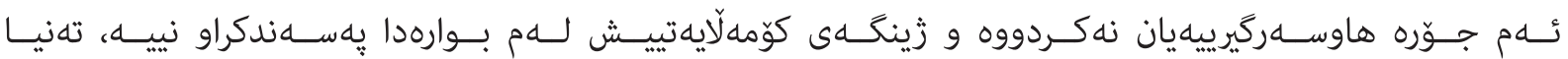

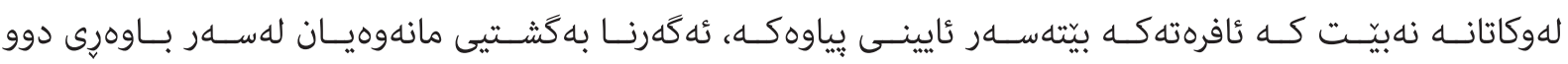

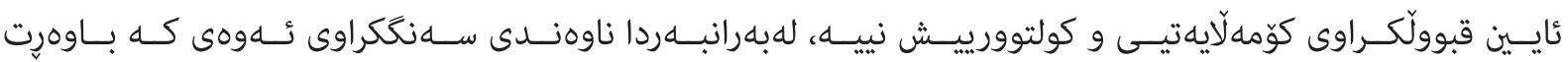

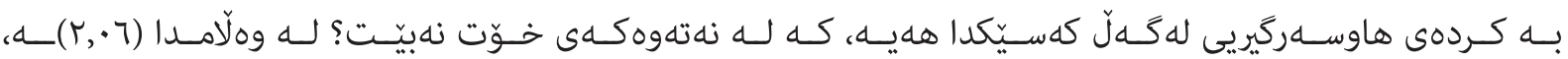

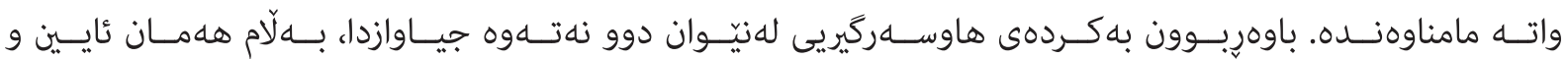

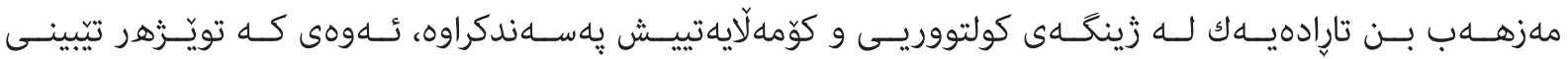

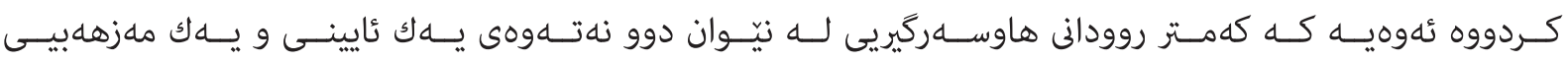

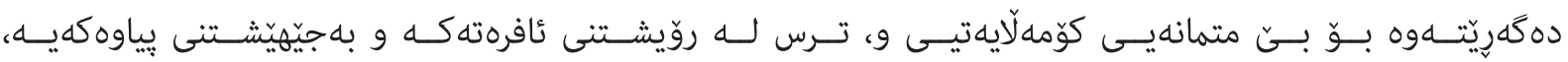

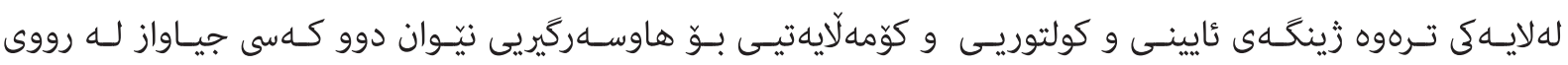

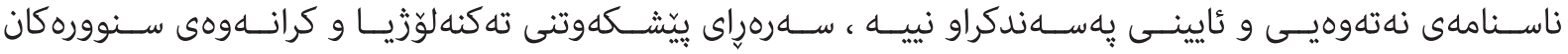

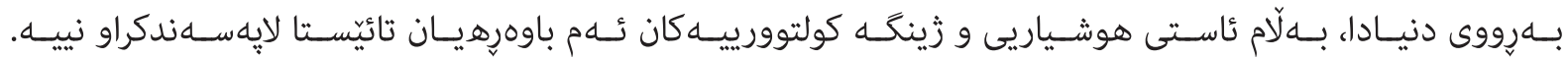

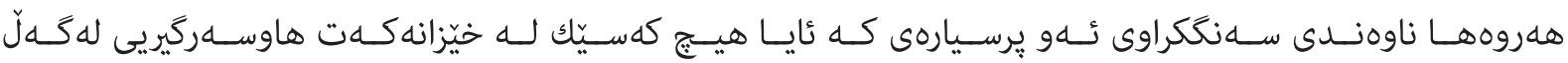

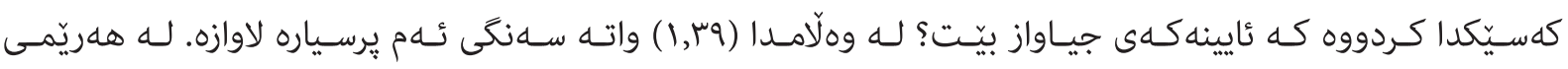

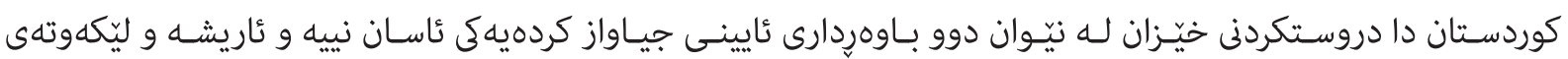

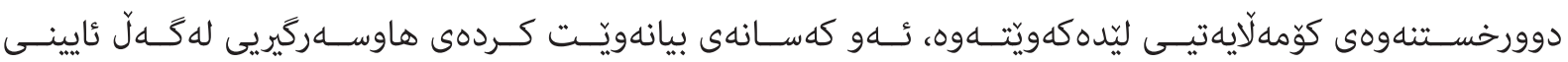

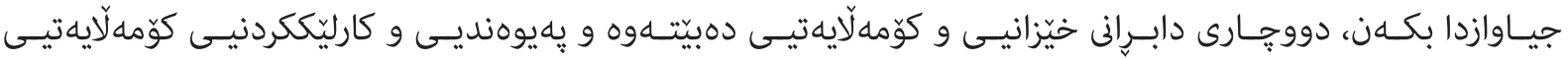

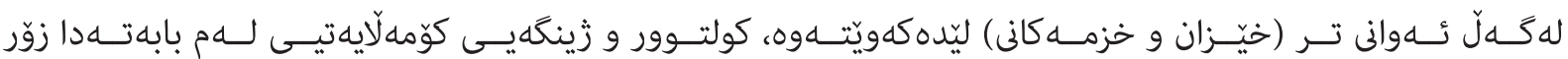

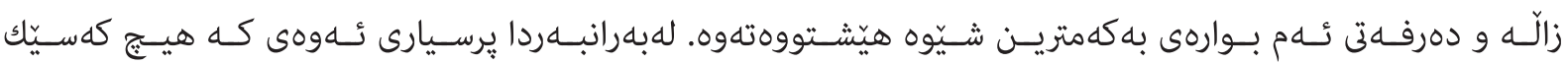

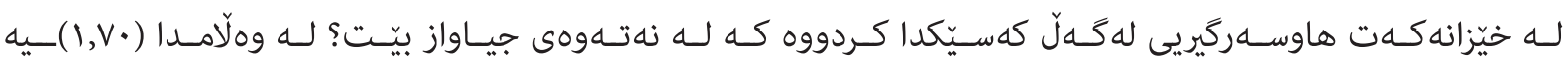

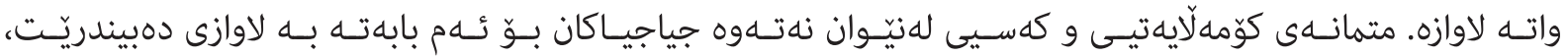

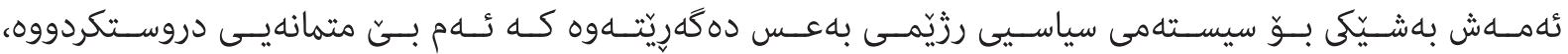




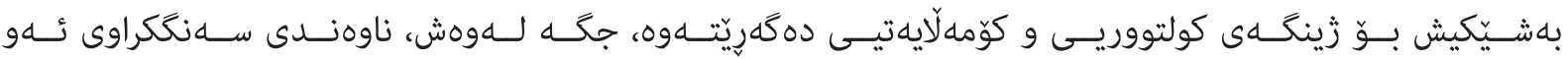

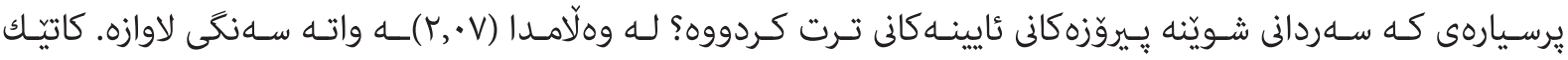

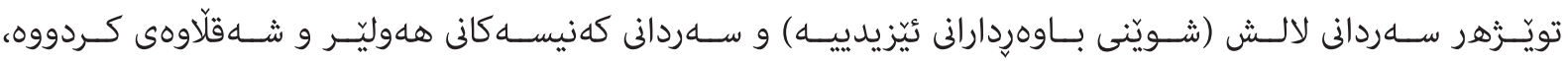

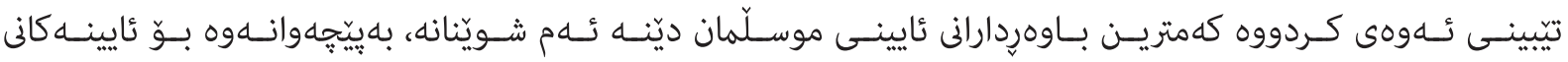

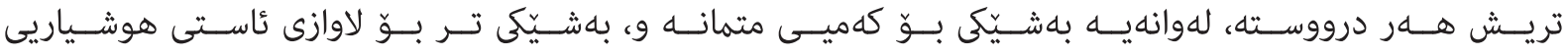

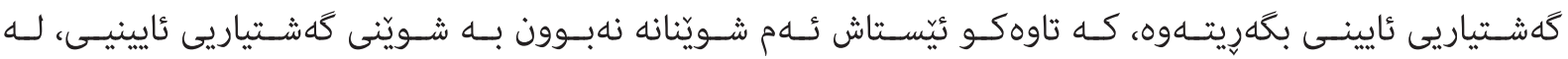

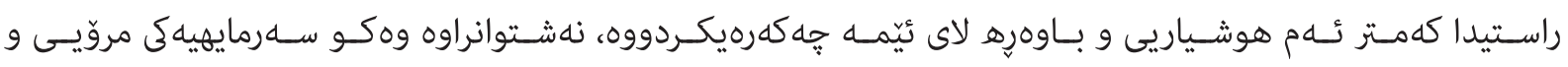

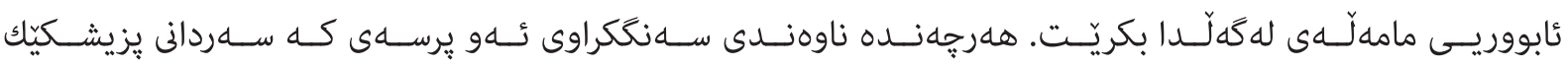

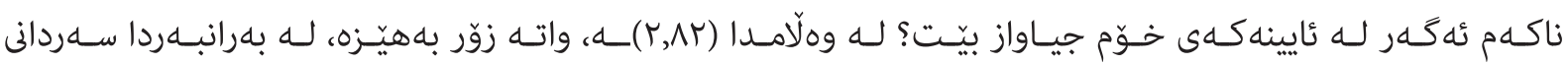

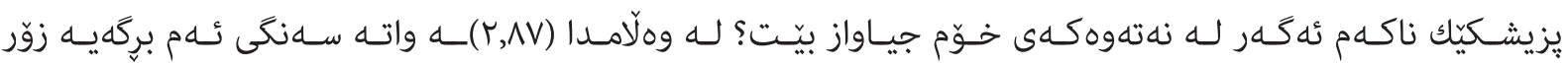

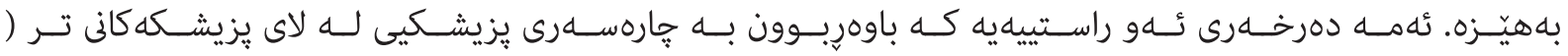

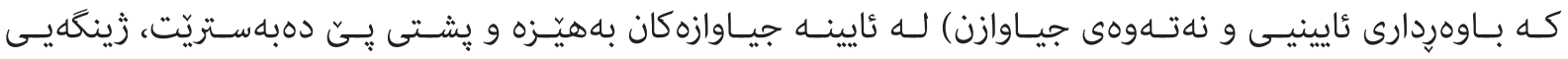

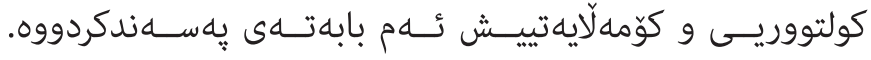

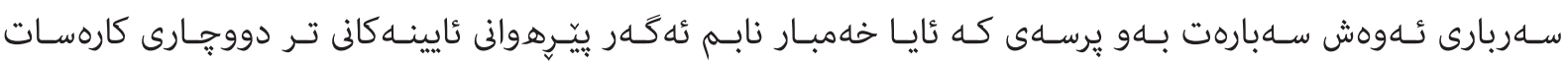

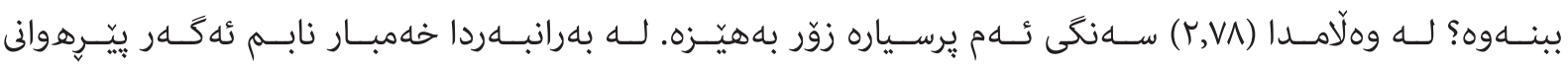

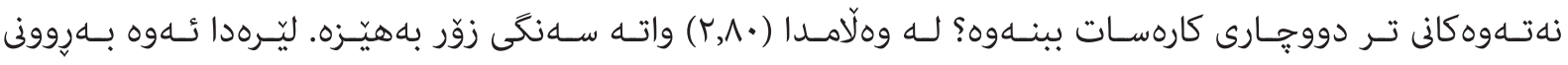

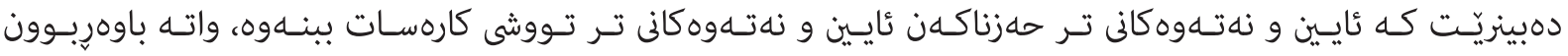

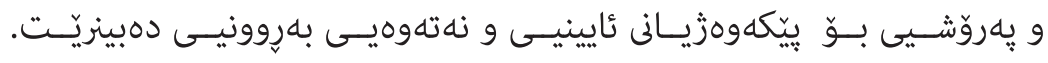

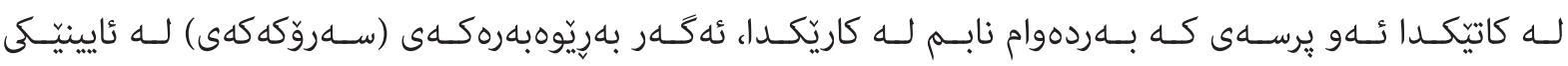

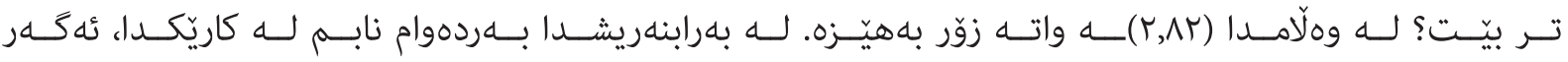

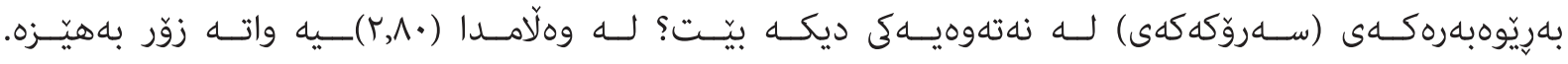

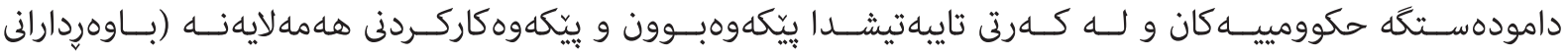

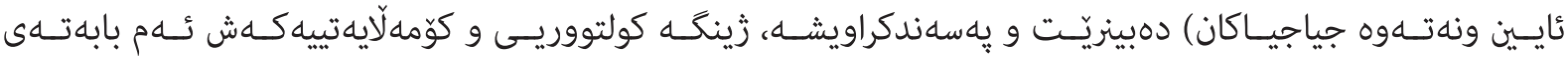

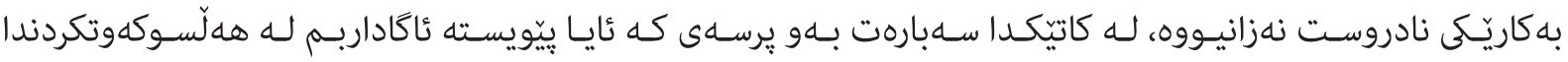

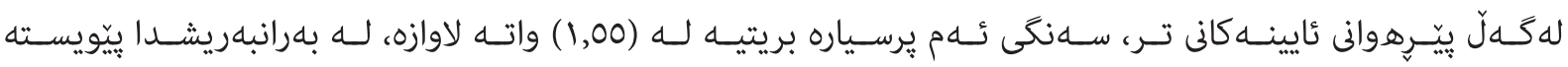

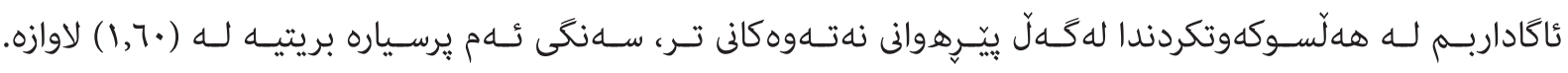

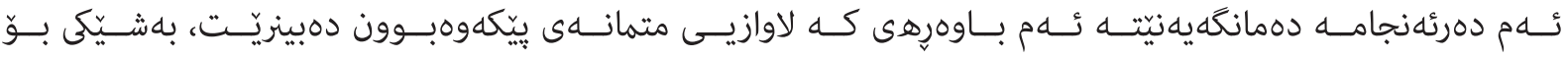

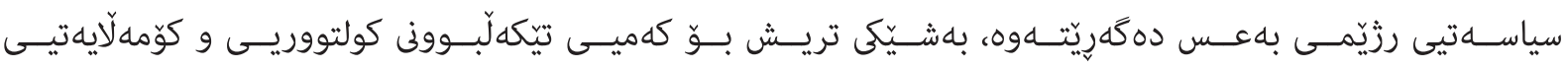

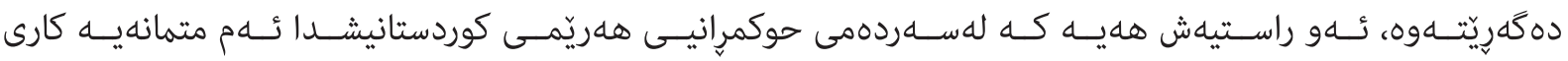

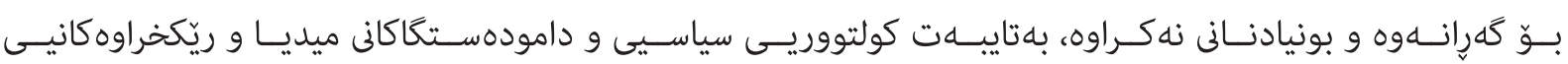

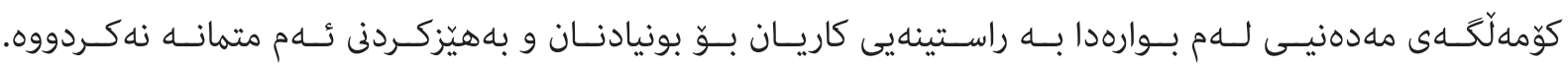

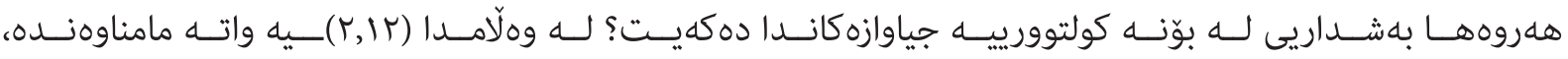

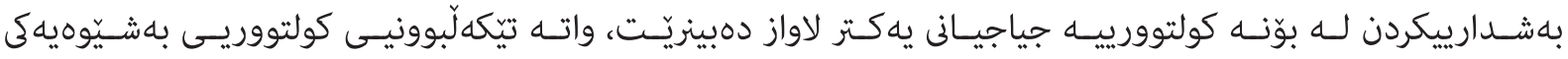




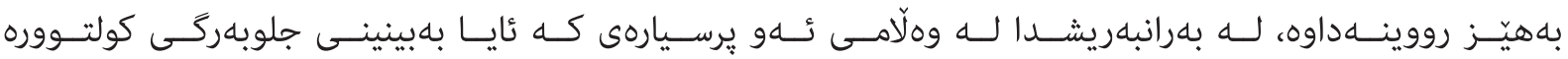

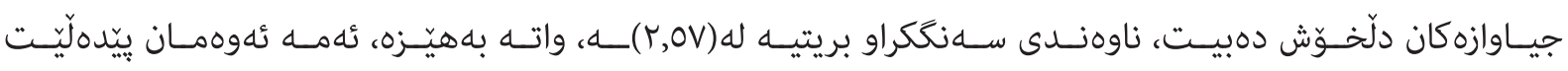

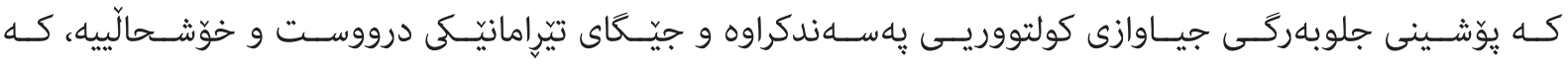

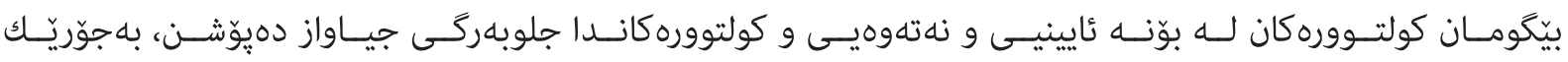
رهنكَدانـهومى داب ونهريتهكـهى خوّيانـه.

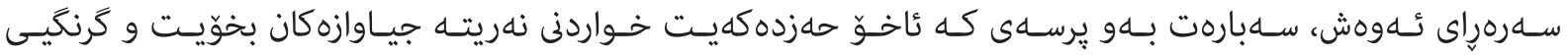

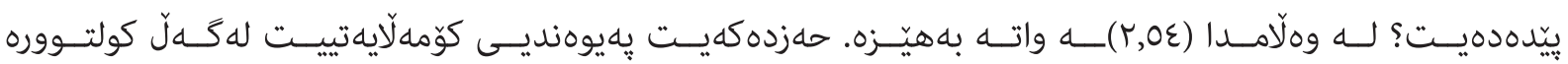

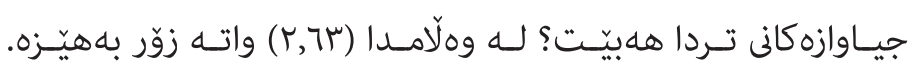

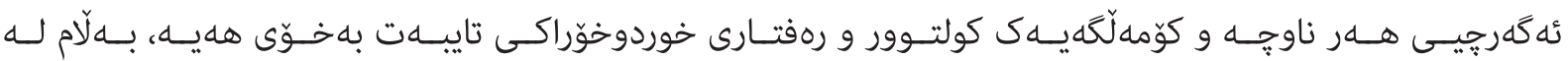

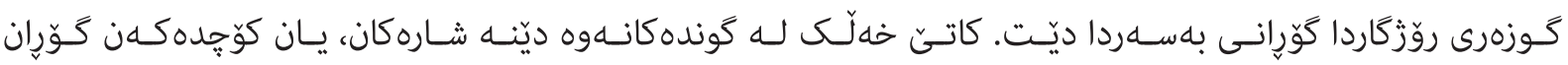

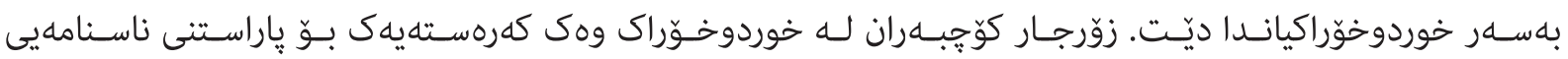

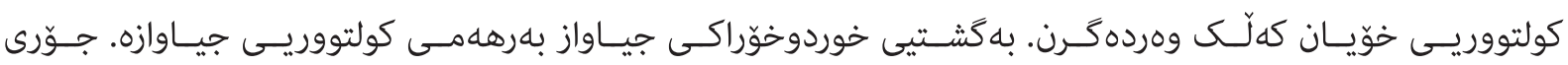

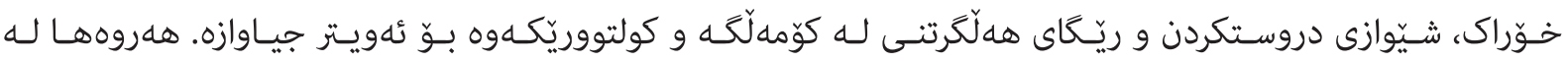

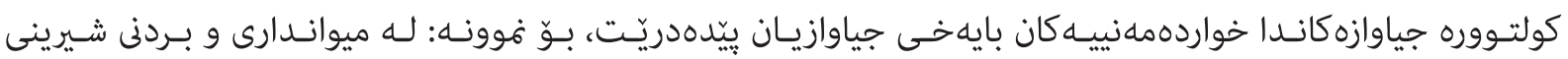

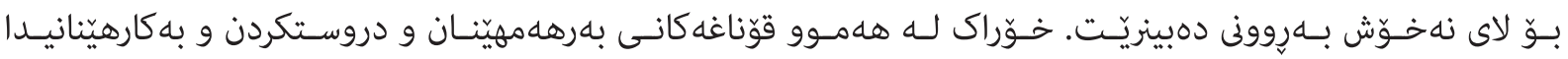

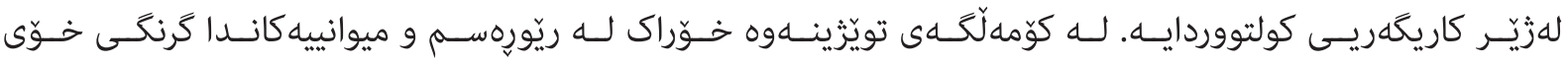

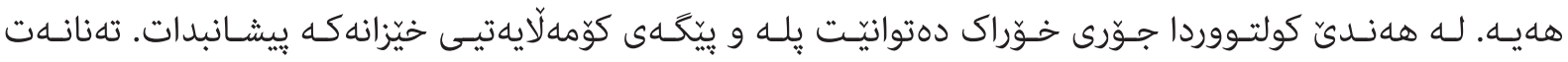

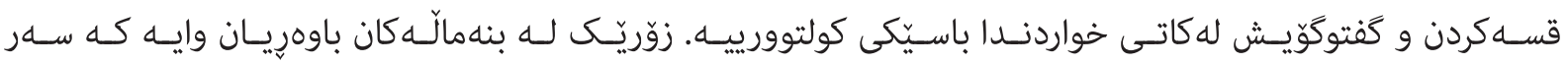

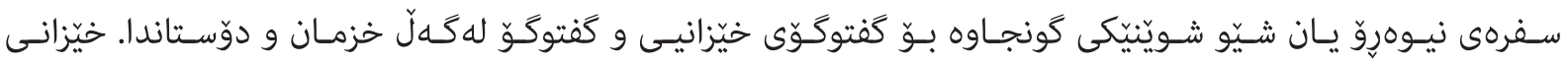

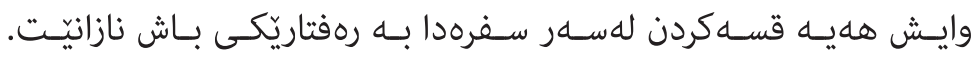

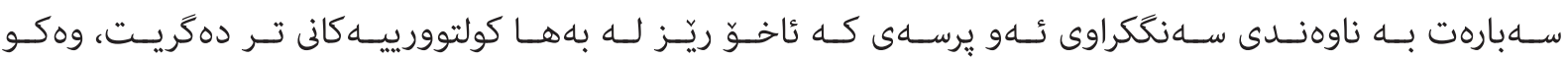

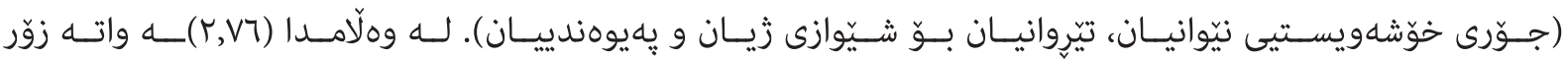

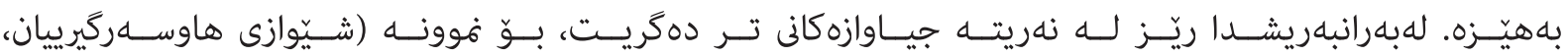

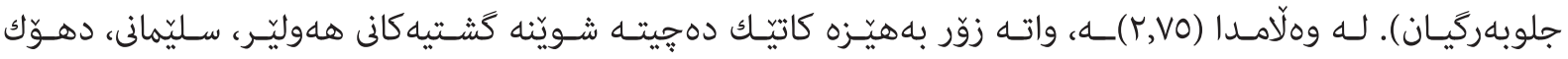

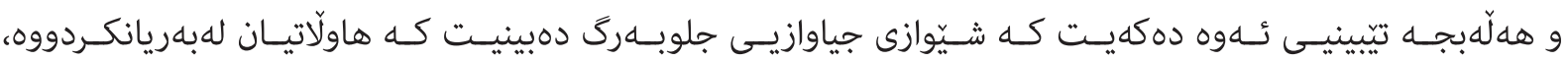

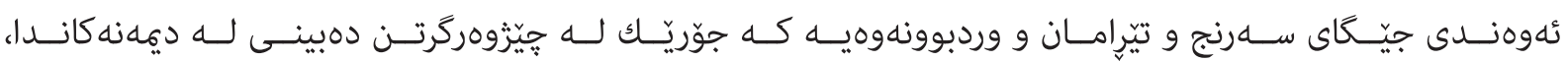

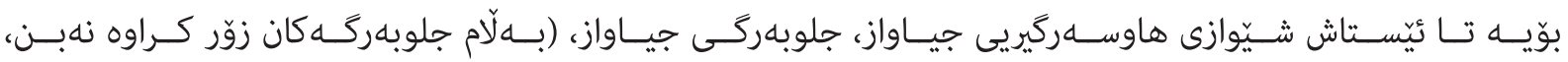

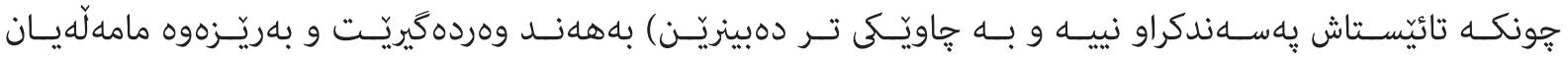

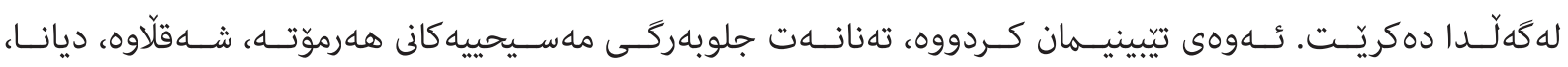

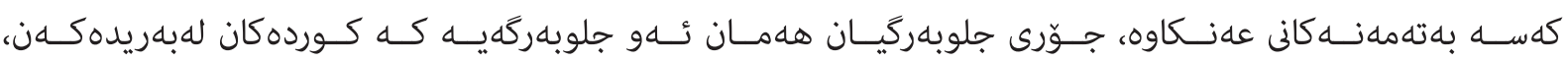

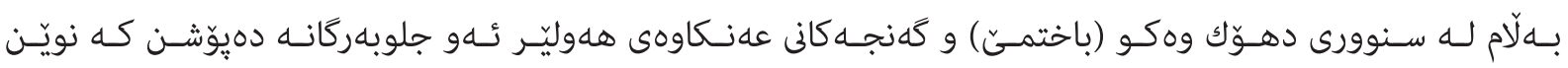

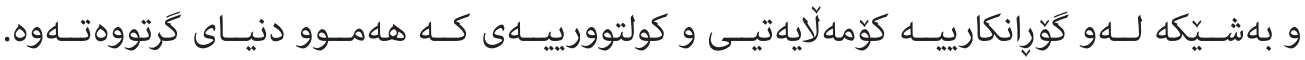

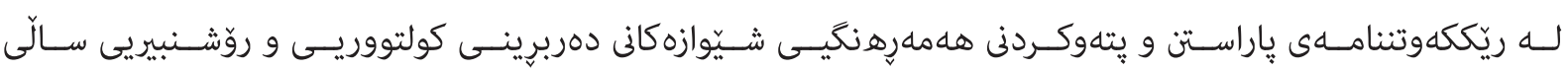




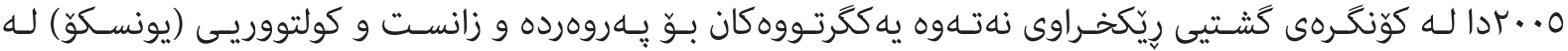

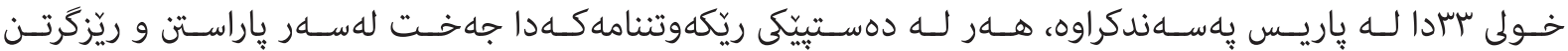

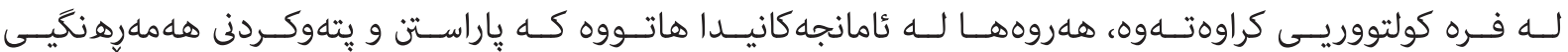

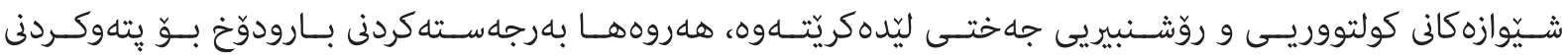

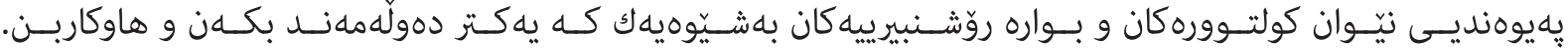

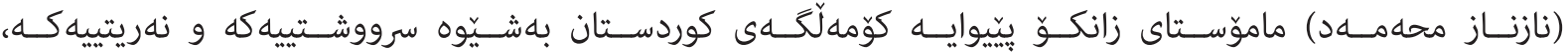

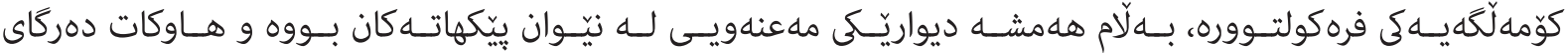

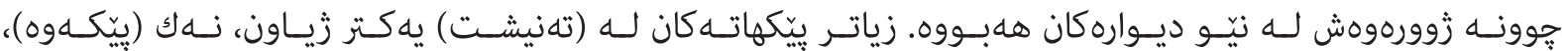

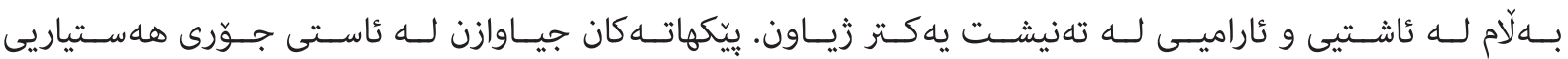

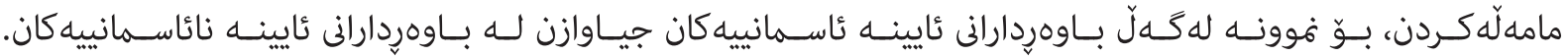

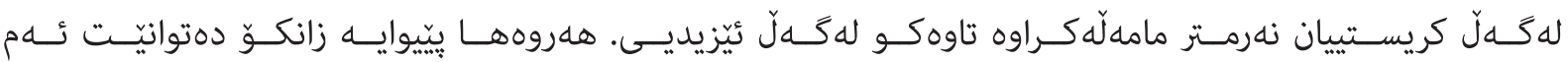

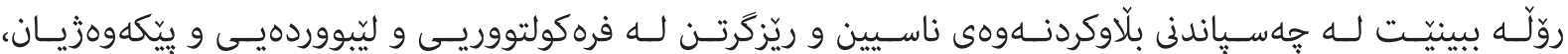

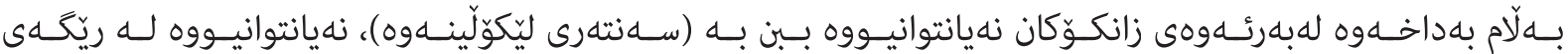

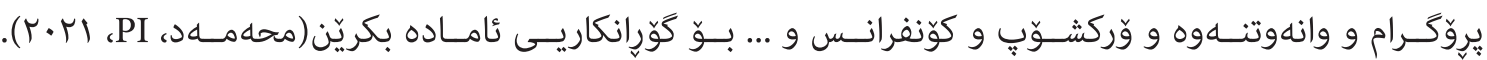

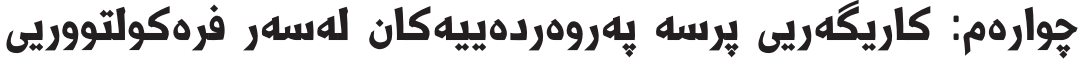

خشتهى (ع) كاريكهريى يهروهرده للههر فرهولتووريى دهخاتهروو

\begin{tabular}{|c|c|c|c|}
\hline$=\frac{b}{3}$ & 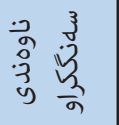 & يرسيار & رههندند \\
\hline$\%, 00,0$ & 2.11 & 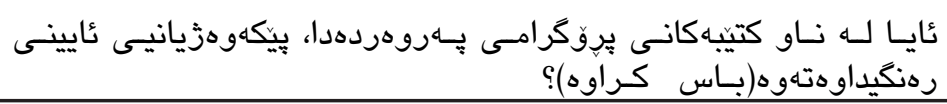 & \multirow{6}{*}{ 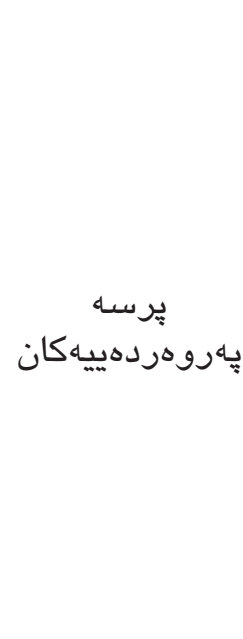 } \\
\hline$\%$. & $r, \cdot \wedge$ & 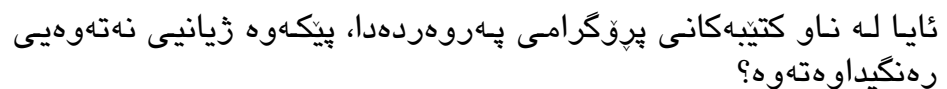 & \\
\hline$\% V r$ & 2.44 & لـايينى قوتابخانه، زانكو، يانَ لـه كاتى كاركردندا لهكهل كهسـانى بروادارى & \\
\hline$\% 9 r$ & $r, \wedge T$ & 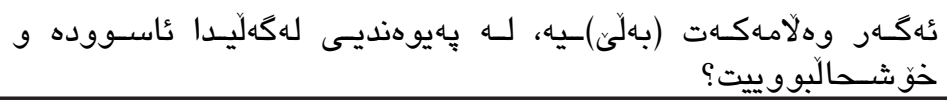 & \\
\hline$\% V r$ & $r, \varepsilon \varepsilon$ & 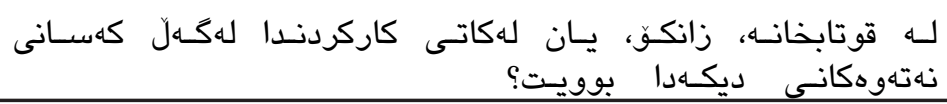 & \\
\hline$\% 91,0$ & $r, \wedge \Gamma$ & 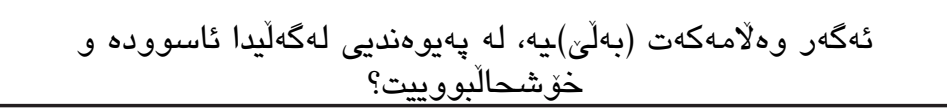 & \\
\hline
\end{tabular}

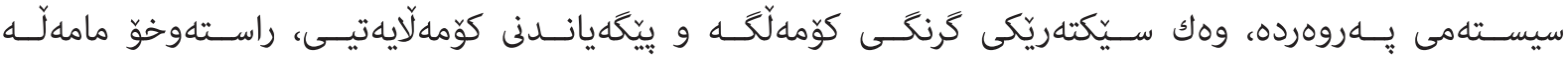

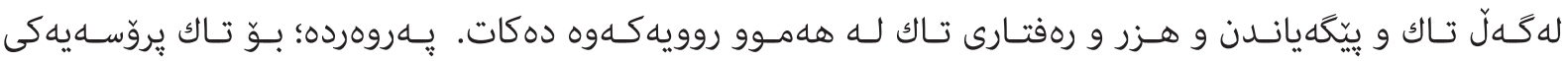

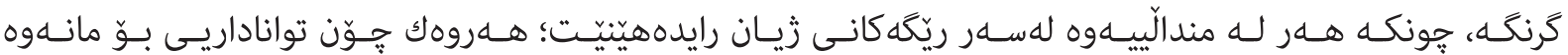
و ياريّزكارييكـردن لـه خـوّى و ياراسـتنى نامانجه كانسى زيانسى دهكات.

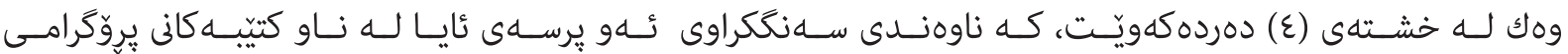




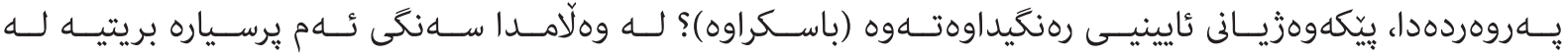

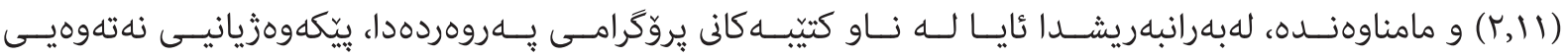

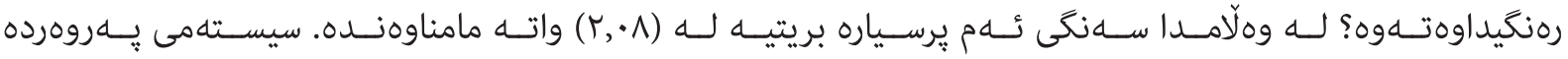

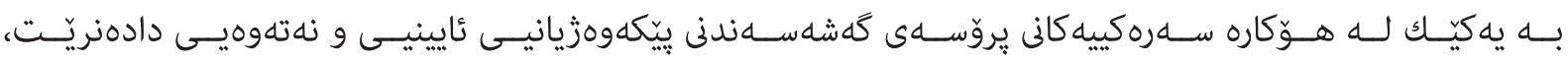

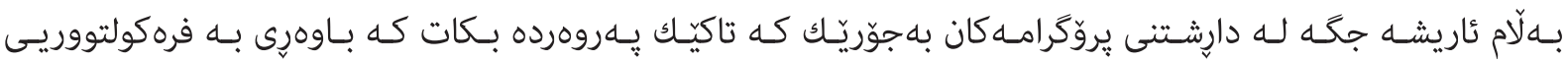

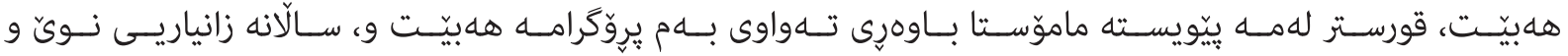

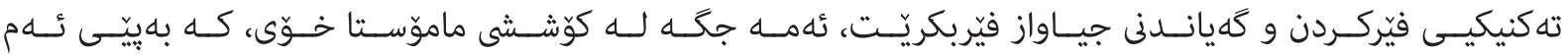

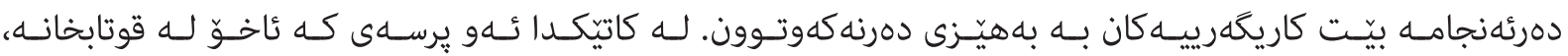

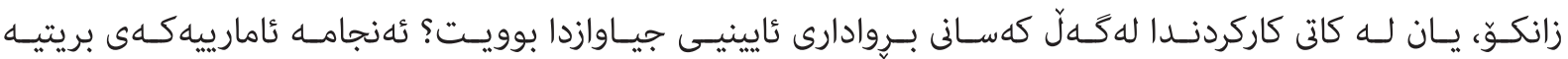

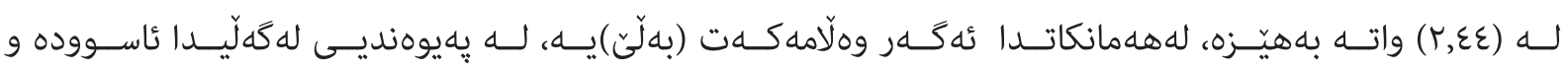

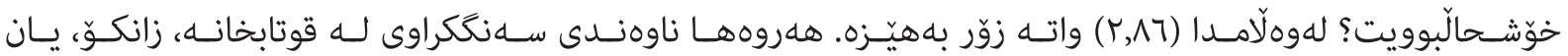

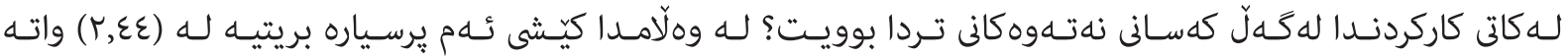

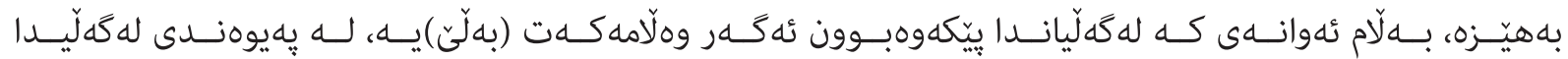

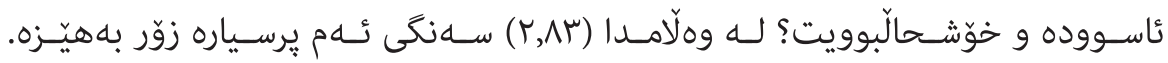

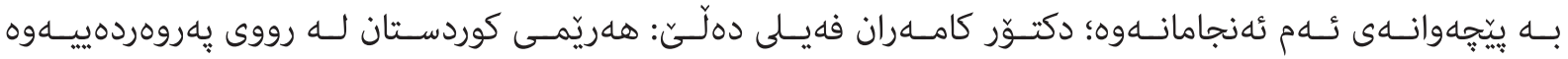

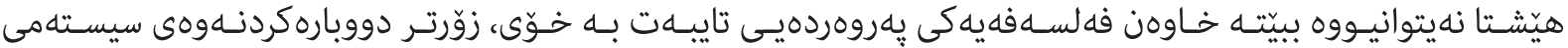

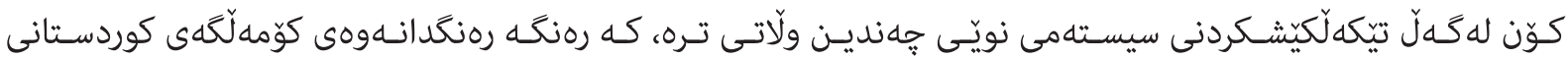
كهمـتر تيَـدا بهديدهريَتـت.

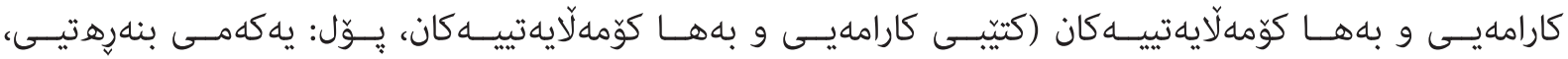

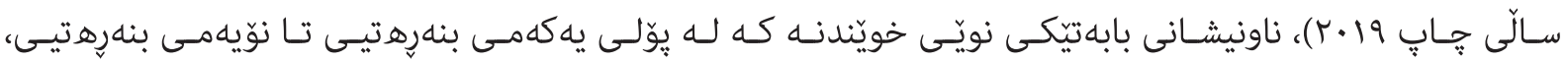

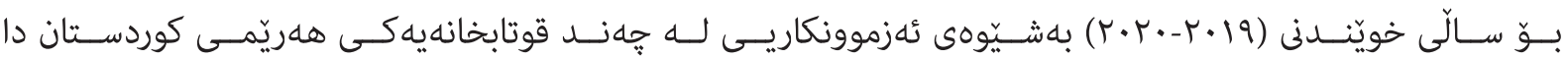

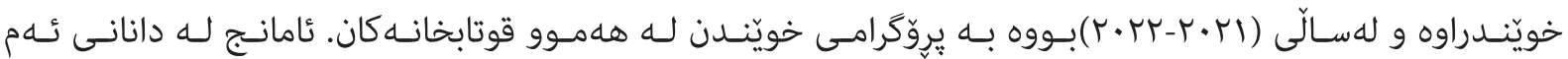

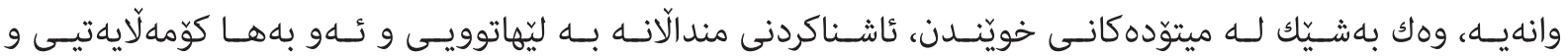

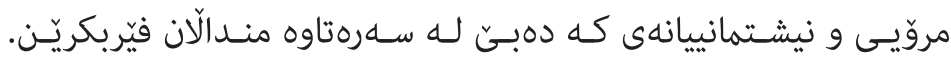

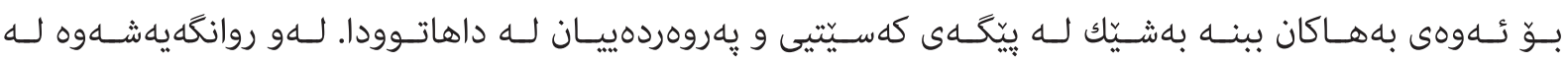

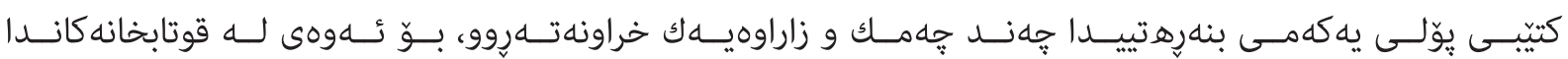

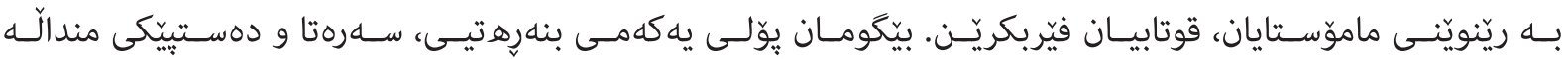

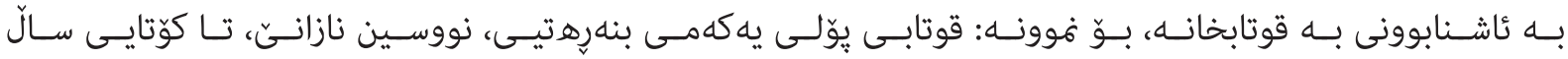

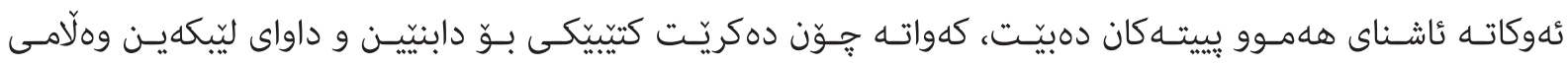

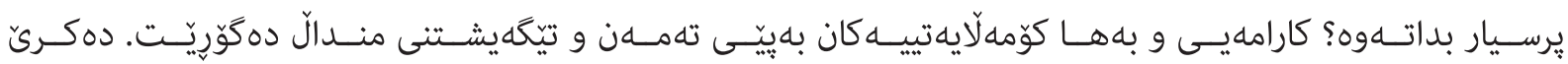

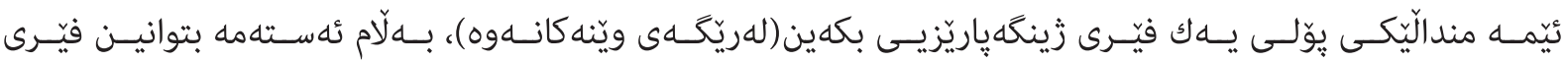

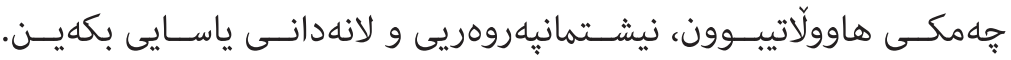

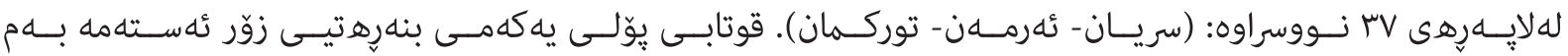




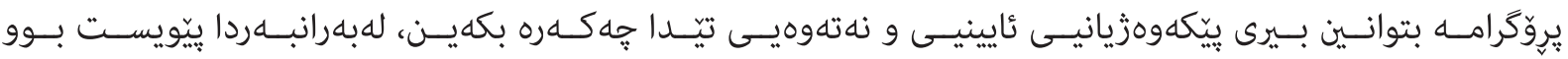

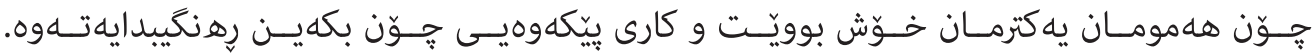

\section{كُهنجام و راسيّارده و يِّنشنياز يهكهم: ئهنجامهكان}

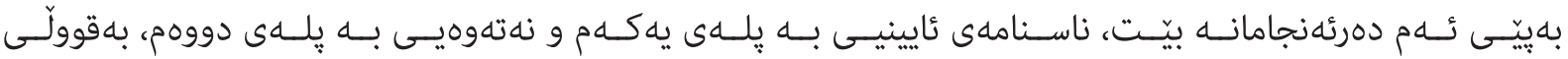

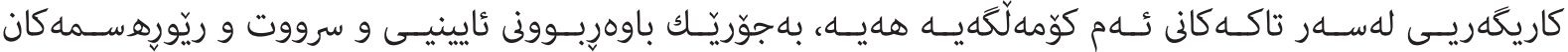

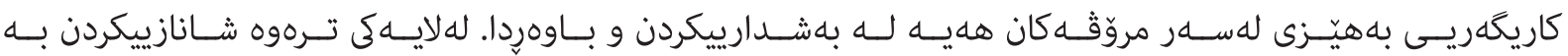

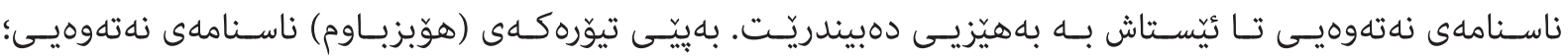

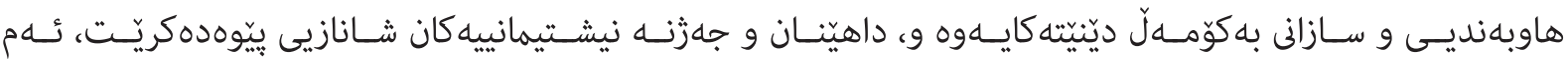

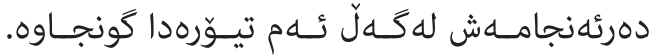

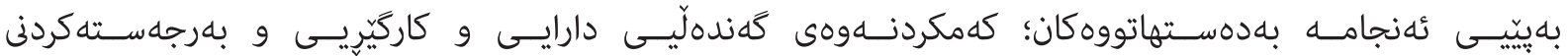

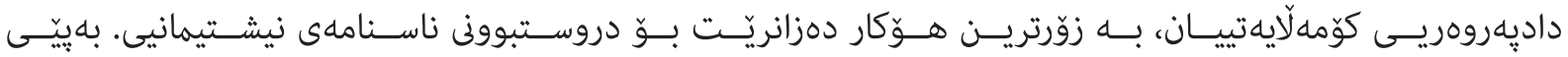

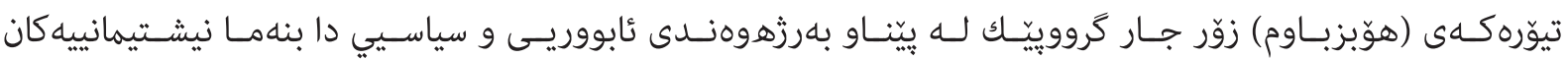

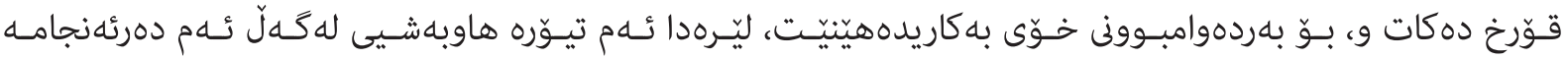
درووسـتكردووه.

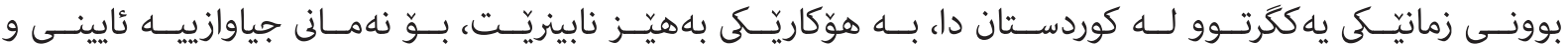

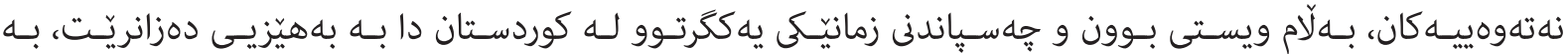

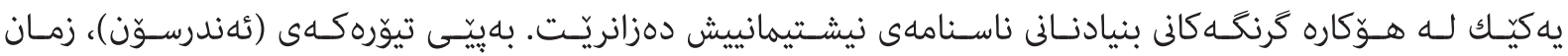

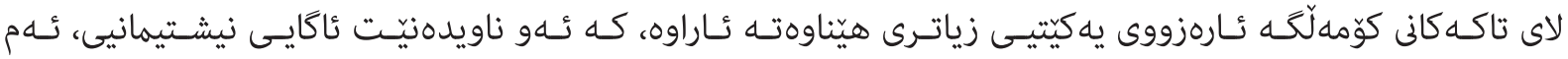

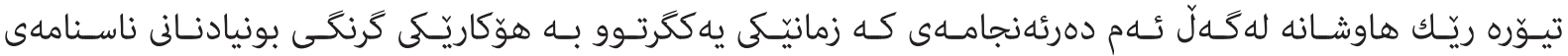
نيشـتيمانيى دادهنيَـت.

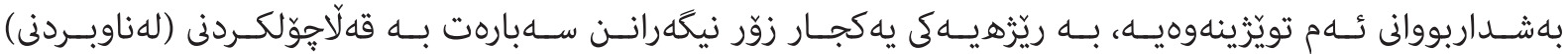

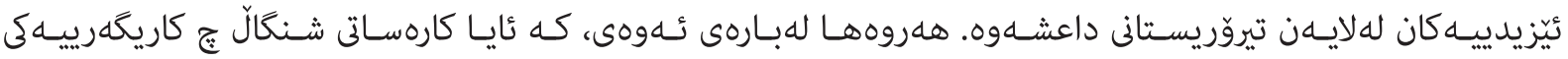

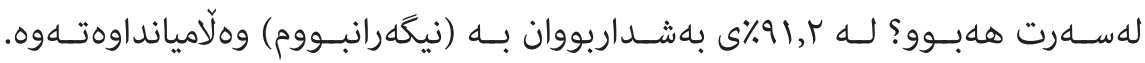

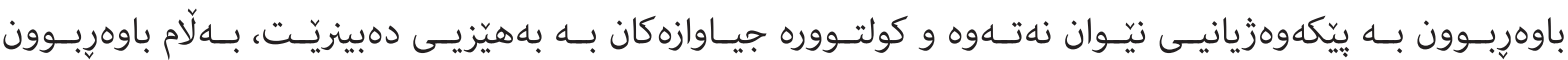

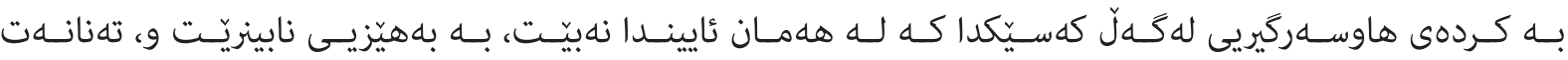

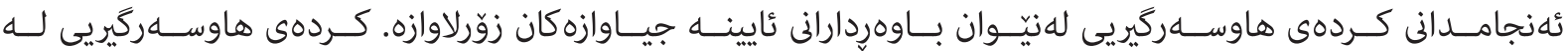

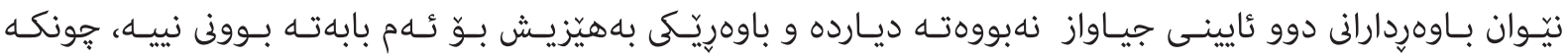

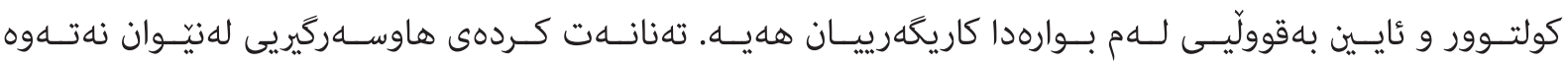

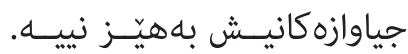

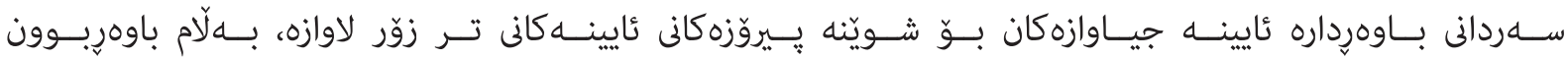

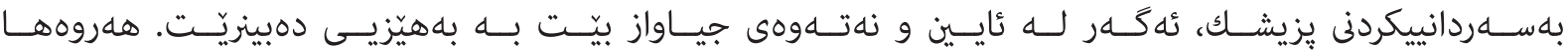




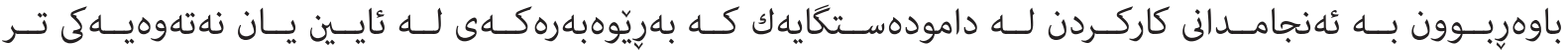

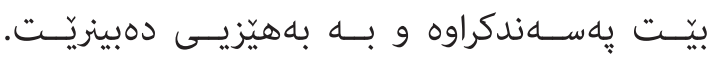

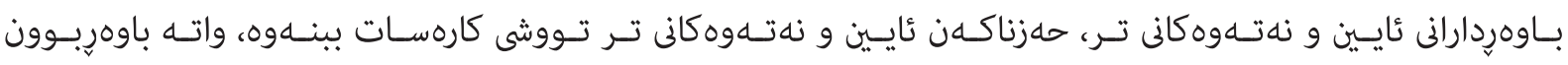

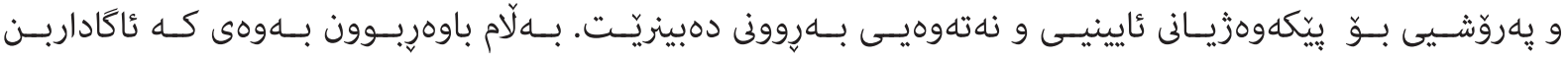

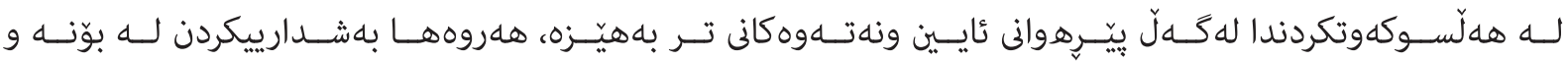

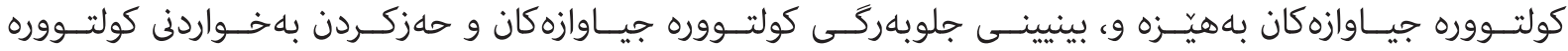
جياجيـاكان، دلّخوّشـيى بــوّ هلمــووان بهرجهســـه دمكات.

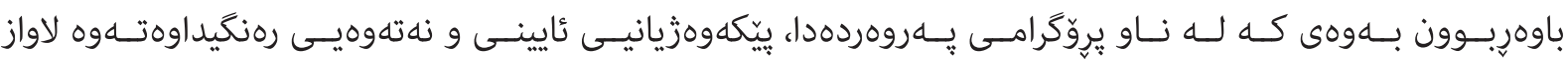

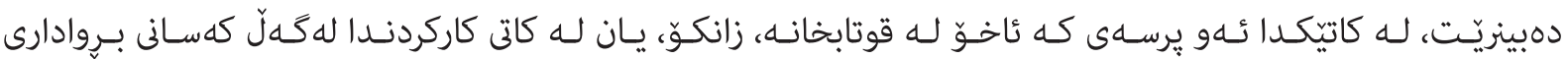

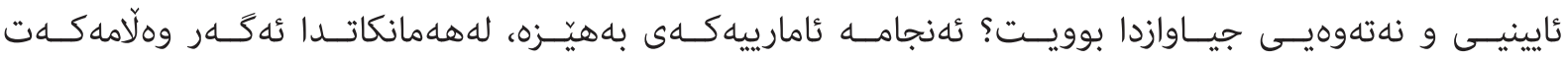

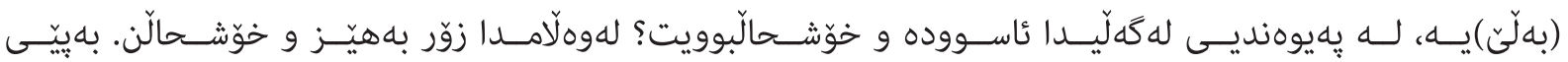

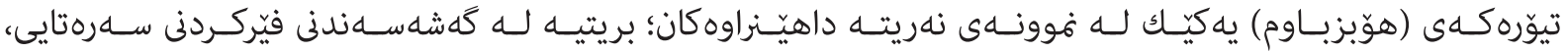

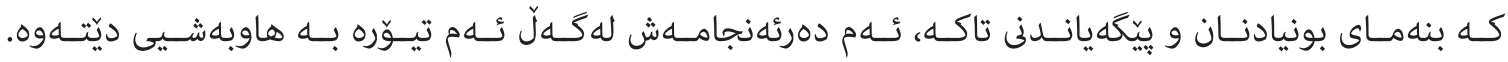
دووهم: راسيارده و يِّشنياز:

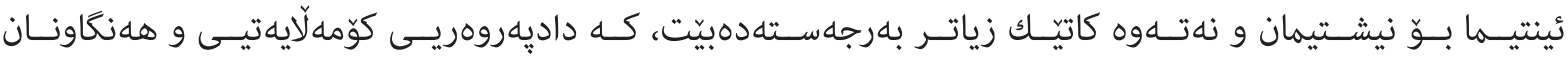

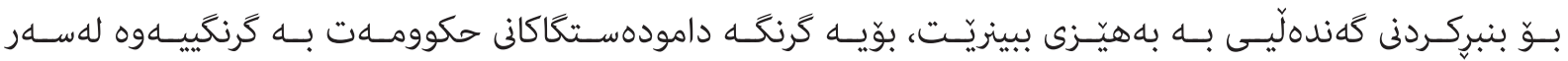
ئسهم بابهتـه كاربكـهن.

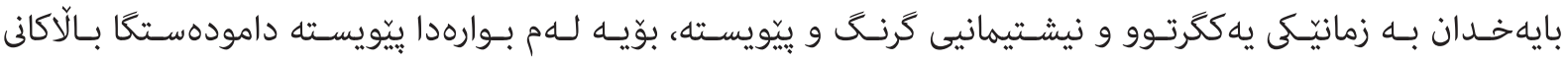
نيشـتيمان هلنـكاوى كرداريسى بنيــن.

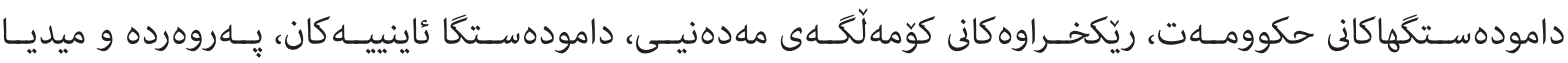

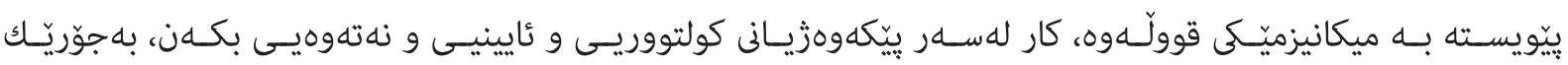

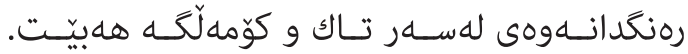

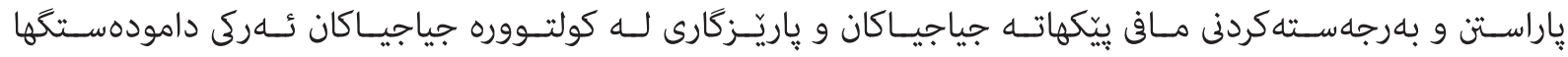

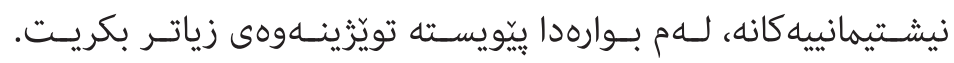




\section{علاقة التعددية الثقافية بالهوية بحث ميدانى في اقليم كردستان}

الملخص

المجتمـع المتعـدد الثقافـة مكـون مـن العديـــ مـن الثقافـات والاديـان المختلفـة وهـــه سـمة مـن سـمات المجتمعـات

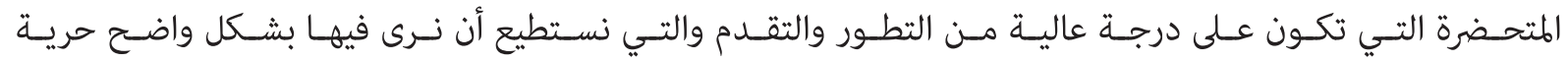

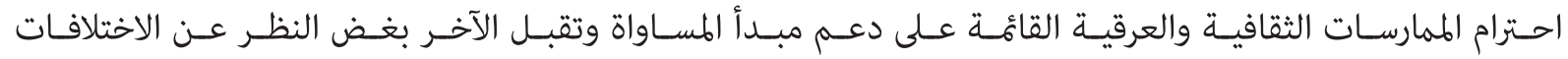

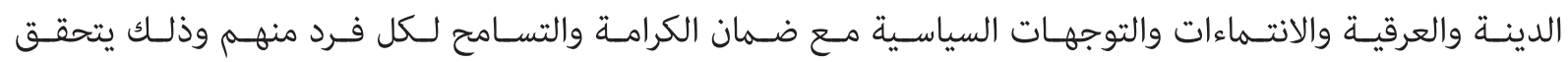

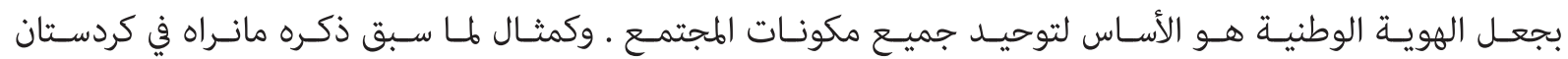

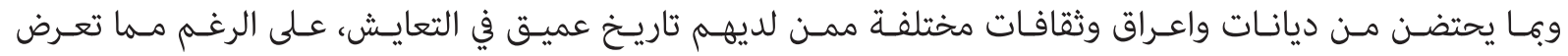

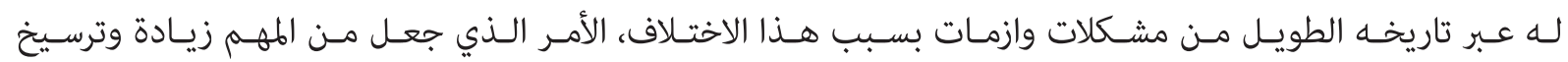

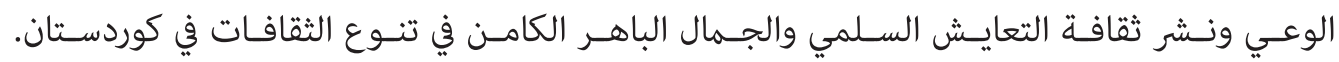

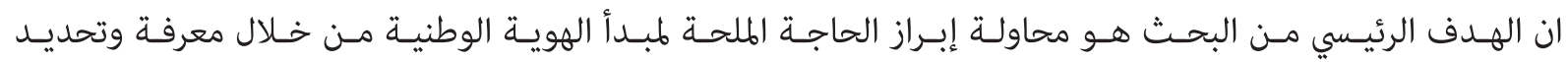

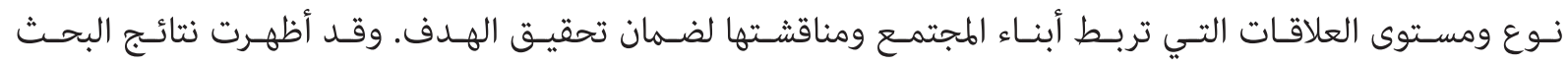

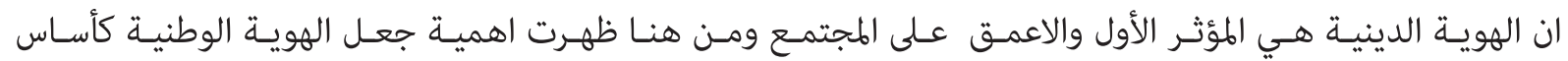

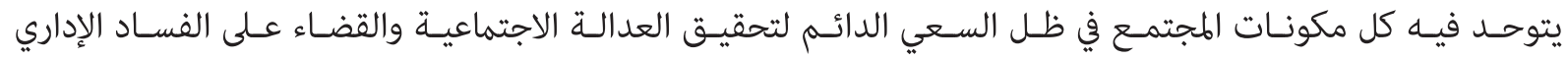

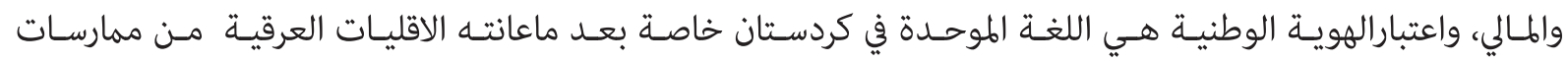

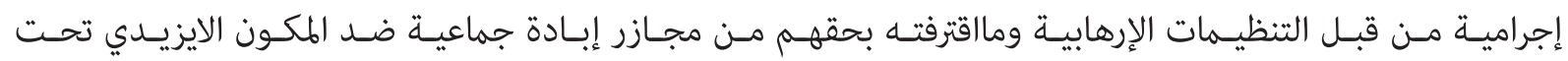

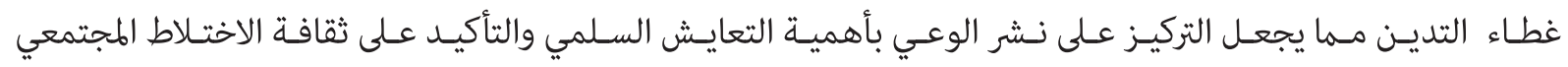

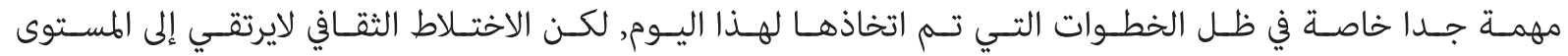
المطلـوب. في هـــا البحـث تـم اسـتخدام طريقـة المـزج وطريقـة التحليـل التسلسـلي والطريقـة المختلطـة حيـث أظهــرت النتائهج ومـن خـلال جـودة البيانـات انهـا تدعـم التحليـل الكمـي للبيانـات. 


\title{
The Relationship of Multiculturalism to Identity Research of Field in Kurdistan Region
}

\begin{abstract}
A multicultural society is being made up of many different cultures, religions and forces, a feature of civilized societies that are at a high degree of development and progress, and in which we can clearly see the freedom to respect cultural and ethnic practices based on supporting the principle of equality and acceptance of the others regardless of their religion, knowledge, affiliation and orientation which is achieved by making the national identity, the umbrella that unites all the components of society. As previously mentioned what we see in Kurdistan is obvious example, which embraces different religions, races and cultures who has a deep history of coexistence despite obstructs and problems they have faced throughout their long history together. Therefore, it is important to increase and develop consolidate awareness and spread the culture of peaceful coexistence in Kurdistan and their brilliant beauty inherent in the culture diversity.

The objectives of this research is to highlight the urgent needs for the principle of national identity by knowing and defining the types and levels of relations that bind the members of society and discussing them to ensure achieve their goals. The results of this research showed that religious identity is the first and deepest influence on society, hence the importance of making national identity as a basis in which all components of society are united in light of the constant pursuit of social justice, the elimination of administrative, financial corruption and considering the national identity as the unifying language in Kurdistan. Participants of this research concerned about genocides and crimes conducted against minorities especially Yazidi's components by the terrorist groups of ISIS, therefore this bitter situations again highlighted the important of spread awareness in order to maintain peaceful coexistence and culture interaction, culture mixing up to now has not raised to the desired level required. In this research, the blending method, the triangulation analysis method and the mixed method have used. The results showed that, through the quality of the information, which supports the quantitative analysis of the data.
\end{abstract}

Keywords: Multiculturalism, Identity, Nationality Identity, Coexistence, Social Cohesion.

$$
\begin{aligned}
& \text { سهرجإوهان } \\
& \text { سهرجاوهى كورديى: }
\end{aligned}
$$

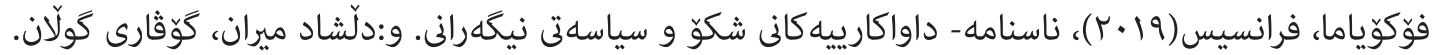

$$
\begin{aligned}
& \text { سهرجاوه عdربيى: }
\end{aligned}
$$

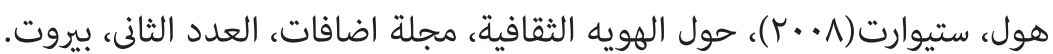

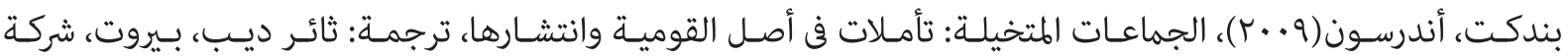




$$
\begin{aligned}
& \text { قدمس. } \\
& \text { كالفى، لويس جان(^••r) ، حرب اللغات والسياسات اللغويه، ترجمه: د.حسن حمزه، بيروت. }
\end{aligned}
$$

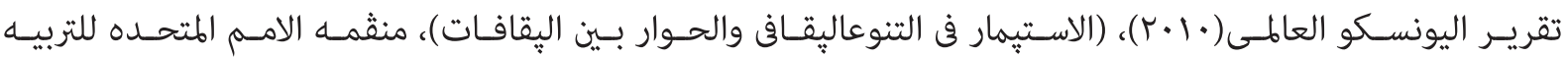

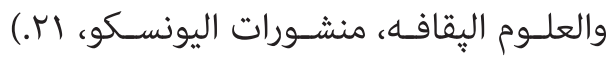

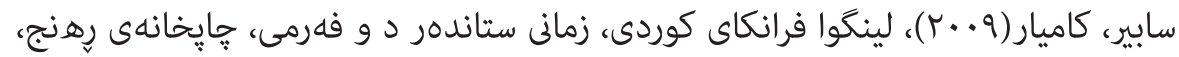

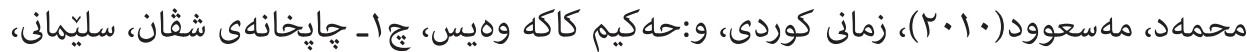
كوش، دونى(r +. (Y)، اليقافه فى العلومالاجتماعيه، ترجمه:د.قاسم المقداد، منشورات اتحاد الكتاب العرب، دمشق. هوبزباوم، اريك(1999)، الامم والنزعه القوميه، ترجمه: عدنان حسن، ط ا، (بيروت ودمشق). سهرجاوهى ئينكليزيى:

Benhabib, S. (2002). The claims of culture: equality and diversity in the global era, Princeton University press.

Benhabib, S. (2011). Dignity and adversity-human rights in troubled times, polity press.

Blaikie, W. H. Norman (1991). A critique of the use of triangulation in social research. Quality and Quantity, victoria University of Technology, volume 25, issue 1, Australia.

Holland, D. et.al (1998). Identity and agency in Cultural H Harvard University press.

Jacobson, J. (1998). Islam in Tradition: Religion and Identity among British Pakistani Youth, London. Rutledge.

Jenkins, R. (1996). Social Identity. London. Rutledge.

Mead, J. (1964). On social F Selected papers. Chicago: University of Chicago press.

Shwani, D. L. (2021). The Importance of Triangulation Methodology in Sociology, Qalaai Zanist journal,VoL.6 No.2,2021

Tajfel, H. (1976). Differentiation Between Social Groups: Studies in the Social Psychology of Intergroup Relations, London. Academic press.

kymlicka, W. (2002) contemporary political philosophy: An introduction, oxford university press.

$$
\text { مالّلهِ ر: }
$$

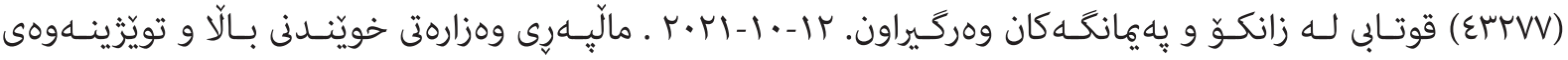
زانسـتى.

https://gov.krd/mohe/activities/news-and-press-releases/2021/october/

\section{جاويّيكهوتنى تايبهت (Personal interview):}




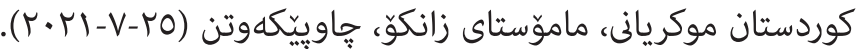

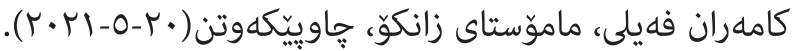

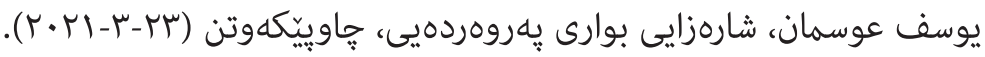

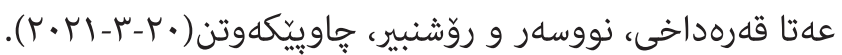

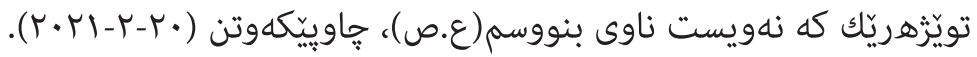

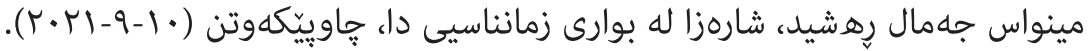

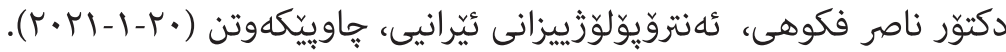

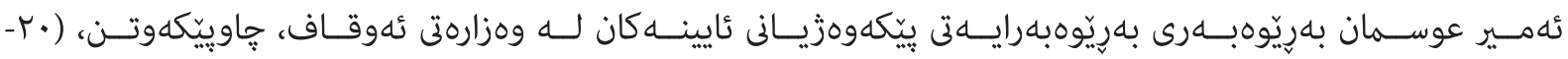
$(r \cdot r \cdot-r)$

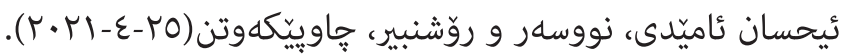
نازناز محمد مهلا قادر، ماموّستاى زانكوّ و تويَزْهر، (Y-YI-V-YV).

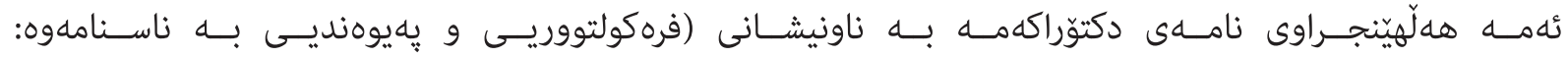

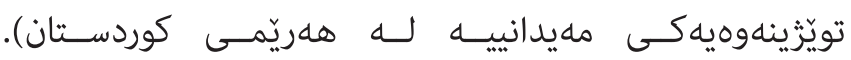

